\title{
PRODUÇÃO DE MUDAS DE CITROS EM VASOS EM FUNÇÃO DA ADUBAÇÃO COM NITROGÊNIO, FÓSFORO E POTÁSSIO
}

\author{
ALBERTO CARLOS DE CAMPOS BERNARDI
}

Engenheiro Agrônomo

Orientador: Prof. Dr. QUIRINO AUGUSTO DE CAMARGO CARMELLO

Tese apresentada à Escola Superior de Agricultura "Luiz de Queiroz", da Universidade de São Paulo, para a obtenção do título de Doutor em Agronomia, Área de Concentração:

Solos e Nutrição de Plantas.

PIRACICABA

Estado de São Paulo - Brasil

Março - 1999

25104109 


\section{Dados Internacionais de Catalogação na Publicação (CIP) DIVISÃO DE BIBLIOTECA E DOCUMENTAÇĀO - Campus "Luiz de Queiroz"/USP}

Bernardi, Alberto Carlos de Campos

Produção de mudas de citros em vasos em função da adubação com nitrogènio, fósforo e porássio / Alberto Carlos de Campos Bernardi. - - Piracicaba, 1999.

84 p. : il.

Tese (doutorado) - - Escola Superior de Agricultura Luiz de Queiroz, 1999. Bibliografia.

1. Adubação fosfatada 2. Adubação nitrogenada 3. Adubação potassica 4. Cultivo em vaso 5. Exigência nutricional 6 . Larania Valência enxertada $\not h$. Limão Cravo 8. Muda frutifera 9. Porta-enxerto 10. Produção vegetal 11 . Viveiro de planta 1. Título 
Ao Criador por mais esta oportunidade, Agradeço.

Aos meus pais, Alberto e Hadiê, Ofereço.

À minha esposa Marta, Dedico. 


\section{AGRADECIMENTOS}

Ao Prof. Dr. Quirino Augusto de Camargo Carmello pela orientação e apoio que possibilitaram a realização deste trabalho.

Ao Dr. Sérgio Alves de Carvalho, pelas sugestões e apoio para a realização deste trabalho

Ao Departamento de Solos e Nutrição de Plantas da Escola Superior de Agricultura "Luiz de Queiroz"/USP pela infra-estrutura e pelo apoio durante a realização deste trabalho.

Ao Centro de Citricultura "Sylvio Moreira", do IAC, pela infra-estrutura pelo apoio durante a condução do experimento.

Ao Conselho Nacional de Pesquisa (CNPq) pelo apoio financeiro através da Bolsa concedida.

À Fundação de Amparo à Pesquisa no Estado de São Paulo (FAPESP), pelo financiamento concedido para a execução do projeto.

Ao Dr. Eduardo Caruso Machado, Camilo Lázaro Medina e Mara de Menezes de Assis Gomes, pelo apoio para a realização das avaliações da fotossintese.

Aos funcionários do Departamento de Solos e Nutrição de Plantas da ESALQ/USP: Alexandre de Oliveira, Edinéia Cristina S. Mondoni, Lurdes A. Dário de González, Lúcia Helena S. Pavan Forti, Nivanda Maria de Moura, Mirtes Ventura Sesso e Sueli Maria Amaral Campos Bovi, pelo auxilio prestado na condução deste estudo e na realização das análises químicas.

Aos amigos do CPG - Solos e Nutrição de Plantas pela amizade, convivio e auxilio nas fases de elaboração deste trabalho.

$\grave{A}$ todas pessoas que não foram mencionadas mas que auxiliaram de alguma forma para que este trabalho pudesse ser realizado com êxito. 


\section{SUMÁRIO}

RESUMO

Página

SUMMARY

vi

1 INTRODUÇÃO

viii

2 REVISÃO DE LITERATURA

2.1 Produção de mudas de citros em vasos

2.2 Nitrogênio, fósforo e potássio na nutrição mineral de citros

2.3 Adubação das mudas de citros

2.4 Diagnose foliar

3 CRESCIMENTO E PRODUÇÃO DE MATERIAL SECO DE MUDAS DE CITROS CULTIVADAS EM VASOS EM FUNÇÃO DA ADUBAÇÃO COM NITROGÊNIO, FÓSFORO E POTÁSSIO

Resumo

Summary

3.1 Introdução

3.2 Material e Métodos

3.2.1 Delineamento experimental

3.2.2 Tratamentos

3.2.3 Instalação e condução

3.2.4 Análise estatística

3.3 Resultados e Discussão

3.4 Conclusões

4 FOTOSSINTTESE DE MUDAS DE CITROS CULTIVADAS EM 32 VASOS EM FUNÇÃO DA ADUBAÇÃO COM NITROGÊNIO, FÓSFORO E POTÁSSIO

Resumo

Summary

4.1 Introdução

4.2 Material e Métodos

4.2.1 Avaliações 
4.2.3 Determinação dos teores totais de nutrientes nos tecidos 37

4.2.4 Análise estatística $\quad 37$

4.3 Resultados e Discussão 39

4.4 Conclusões 49

5 TEORES E ACUMULAÇÃO DE MACRONUTRIENTES EM MUDAS 50 DE CITROS CULTIVADAS EM VASOS EM FUNÇÃO DA ADUBAÇÃO COM NITROGÊNIO, FÓSOFORO E POTÁSSIO

Resumo

Summary

5.1 Introdução

52

5.2 Material e Métodos $\quad 54$

5.2.1 Amostragem $\quad 55$

5.2.2 Determinação dos teores totais de nutrientes nos tecidos 55

5.2.3 Análise estatística $\quad 55$

5.3 Resultados e Discussão 59

5.3.1 Teores de nutrientes nos tecidos $\quad 59$

5.3.2 Acumulação de nutrientes $\quad 69$

5.4 Conclusões $\quad 72$

6 CONCLUSÕES GERAIS $\quad 73$

REFERÊNCIAS BIBLIOGRÁFICAS $\quad 74$ 


\title{
PRODUÇÃO DE MUDAS DE CITROS EM VASOS EM FUNÇÃO DA ADUBAÇÃO COM NITROGÊNIO, FÓSFORO E POTÁSSIO
}

\author{
Autor: Alberto Carlos de Campos Bernardi \\ Orientador: Prof. Dr. Quirino Augusto de Camargo Carmello
}

\section{RESUMO}

O objetivo deste trabalho foi avaliar a produção do porta-enxerto e das mudas de mudas de citros em resposta à adubação com os nutrientes N, P e K. Mudas de laranjeira 'Valência' (Citrus sinensis L. Osbeck) sobre porta-enxerto limoeiro 'Cravo' ( $C$. limonia Osbeck) foram cultivadas em ambiente protegido em vasos com capacidade para 3,8 L com substrato a base de casca de Pinus, vermiculita e perlita,

Utilizou-se um esquema fatorial fracionário $(1 / 5) 5^{3} \mathrm{com}$ um delineamento em blocos casualisados. Os tratamentos ( $\mathrm{g}$ por planta) consistiram em 5 doses de $N: 1,25 ; 6,25 ; 11,25 ; 16,25 ; 21,25 ; 5$ doses de $\mathrm{K}: 0,42 ; 3,75 ; 6,22 ; 9,34$; 12,45 e 5 doses de P: 0,$19 ; 0,89 ; 1,59 ; 2,29 ; 2,99$. N e $\mathrm{K}$ foram fornecidos semanalmente, sendo $37,5 \%$ da dose aplicada na produção do porta-enxerto e $62,5 \%$ após a enxertia. O P foi fornecido todo no plantio do porta-enxerto.

Avaliou-se a produção de material seco das folhas, raizes, caule, parte aérea e total; área foliar, relação raízes/parte aérea; altura de plantas; volume radicular, relação área foliar/material seco para os porta-enxertos e as mudas, e o diâmetro do caule para os porta-enxertos. Além da taxa de assimilação líquida $(A)$, transpiração $(E)$, condutância estomática $(g)$, concentração interna de $\mathrm{CO}_{2}$ (Ci) e eficiência de uso de água (EUA) para ambas plantas. Determinou-se também os teores totais de $\mathrm{N}, \mathrm{P}$ e $\mathrm{K}, \mathrm{Ca}, \mathrm{Mg}$ e $\mathrm{S}\left(\mathrm{g} \mathrm{kg}^{-1}\right)$ nas folhas novas e 
velhas, raizes e caule ( $\mathrm{g}$ por planta) para os porta-enxertos e as mudas. Estabeleceu-se a acumulação N, P e K. Funções de resposta foram ajustadas e os niveis de nutrientes, para se obter as melhores respostas.

Para a produção das mudas, as doses de $\mathrm{N}$ e K, calculadas a partir da área foliar foram sempre maiores que aquelas que somente consideram a produção de material seco total. Isso foi observado tanto na produção dos porta-enxertos de limoeiro 'Cravo', como das mudas de laranjeira 'Valência'l'Cravo'.

As doses excessivas de $\mathrm{N}$ utilizadas limitaram a fotossintese. As doses intermediárias da adubação potássica interferiram positivamente nos parâmetros. O P teve pouca influência nos parâmetros avaliados. No portaenxerto limoeiro 'Cravo', a assimilação de $\mathrm{CO}_{2}$, transpiração, e eficiência do uso da água do foram relacionados com os teores foliares de K. Nas mudas de laranjeira 'Valência', a assimilação de $\mathrm{CO}_{2}$, e a eficiência do uso da água do foram relacionados positivamente com os teores foliares de $\mathrm{K}$ e a concentração interna de $\mathrm{CO}_{2}$ negativamente.

A ordem decrescente dos teores de macronutrientes nos órgãos analisados foram: folhas velhas, folhas novas, raízes e caule. A adubação nitrogenada relacionou-se diretamente com os teores de $\mathrm{N}$ e inversamente como os de $\mathrm{P}$ e K. Os teores de $\mathrm{Ca}$, Mg e S relacionaram-se positivamente com a adubação nitrogenada até os níveis intermediários. Houve efeito inibitório do K sobre a absorção de $\mathrm{Ca}$ e Mg. A acumulação de NPK pelos porta enxertos foi em torno de $30 \%$ pelas raizes e $70 \%$ pela parte aérea. 


\title{
CONTAINERIZED CITRUS NURSERY TREES PRODUCTION DUE TO NITROGEN, PHOSPHORUS AND POTASSIUM FERTILIZATION
}

\author{
Author: Alberto Carlos de Campos Bernardi \\ Adviser: Prof. Dr. Quirino Augusto de Camargo Carmello
}

\section{SUMMARY}

The main objective of this research was to evaluate the Citrus rootstock and nursery trees production due to N, P and K fertilization. 'Valencia' sweet orange nursery trees (Citrus sinensis L. Osbeck) budded on Rangpur lime rootstocks (C. limonia Osbeck) were grown in a protected environment in $3,8 \mathrm{~L}$ containers with Pinus bark, vermiculite and perlite subtract.

The experiment was carried out as a (1/5) $5^{3}$ factorial in a randomized complete block design. Treatments comprised ( $g$ per plant) five levels of $N: 1.25$; $6.25 ; 11.25 ; 16.25 ; 21.25$; five levels of $\mathrm{K}: 0.42 ; 3.75 ; 6.22 ; 9.34 ; 12.45$; and five levels of $P: 0.19 ; 0.89 ; 1.59 ; 2.29 ; 2.99$. Nitrogen and $K$ were applied weekly, and $37.5 \%$ of the total fertilization was applied to rootstocks. All P was supplied at planting.

Leaves, root, stem, shoot and total dry matter production, shoot/root ratio, leaf area, plant height, root system volume, leaf area dry matter ratio of rootstocks and nursery trees and rootstock stem diameter were evaluated. Carbon dioxide assimilation rate $(A)$, transpiration rate $(E)$, stomatal conductance $(\mathrm{g})$, internal $\mathrm{CO}_{2}(\mathrm{Ci})$ were evaluated and the water use efficiency (WUE) was estimated by the relation $A E^{-1}$. Young and old leaves, root and stem total nutrient concentration of $\mathrm{N}, \mathrm{P}, \mathrm{K}, \mathrm{Ca}, \mathrm{Mg}$ and $\mathrm{S}$ were determined. Nitrogen, $P$ and $K$ extraction were calculated. Response functions were adjusted and 
nutrient rates for maximum yield are presented.

Nitrogen and $K$ fertilizers levels calculated by leaf area were always greater than those obtainned by dry matter production. This was observed at 'Valência' sweet orange production and also at 'Rangpur lime' production.

High levels of $\mathrm{N}$ decreased net photosynthesis. Potassium at intermediate fertilization levels had positive effects on the evaluated parameters. Phosphorus had little interference on net photosynthesis. Rangpur lime rootstock $A, E$ and WUE were positively related to $K$ foliar concentration. 'Valencia' nursery trees $A$ and WUE were positively related and $\mathrm{Ci}$ was inversely related to $\mathrm{K}$ foliar concentration.

Macronutrients tissue concentrations decreased in the following order: old leaves, young leaves, roots and stem. Nitrogen fertilization was directly related with tissue $\mathrm{N}$ concentration and inversely with $\mathrm{P}$ and $\mathrm{K}$ concentrations. Calcium, $\mathrm{Mg}$ and $\mathrm{S}$ concentrations increased until intermediate $\mathrm{N}$ fertilization rates. Inhibition of plant nutrient absorption occurred among $\mathrm{K}, \mathrm{Ca}$ and $\mathrm{Mg}$. Rootstocks $\mathrm{N}, \mathrm{P}$ and $\mathrm{K}$ accumulated around $30 \%$ in roots and $70 \%$ in shoot. 


\section{Introdução}

A maior parte da produção citrícola brasileira ( $80 \%$ do total), destina-se ao processamento para transformação em suco concentrado. Este produto é quase totalmente direcionado ao mercado externo. No Estado de São Paulo, a área ocupada com 192,4 milhões de árvores de laranja em produção, em 1997, era de aproximadamente 740 mil hectares. A produção tem sido crescente tendo atingido 383 milhões de caixas neste ano, enquanto a produtividade média vem mantendo-se estável, ao redor de 2 caixas por planta. $O$ número de plantas novas vem sendo reduzido de cerca de $25 \%$ do total de plantas no início da década de 90 , para cerca de $15 \%$ do total de 224,4 milhões de árvores plantadas em 1996/97. Essa redução pode ser atribuída não apenas aos baixos preços recebidos pelos produtores, mas também à problemas fitossanitários que tem provocado a erradicação de pomares no Estado (Amaro \& Maia, 1997).

Existem várias doenças que incidem sobre a cultura dos citros, porém existem duas que são particularmente importantes e podem apresentar suas fases críticas no período de produção de mudas. A clorose variegada dos citros - CVC (causada pela bactéria Xylella fastidiosa) é considerada a principal doença da citricultura brasileira atual. Essa doença é mais severa quando atinge plantas jovens, diminuindo a severidade quando as plantas atingem 8-10 anos. Outra grave doença da cultura no país é a gomose causa por fungos do gênero Phytophthora. Sua incidência em plantios novos é muito elevada devido à produção de mudas em viveiros contaminados com este fungo. Assim, é preciso que se estabeleçam medidas que permitam a obtenção de mudas 
sadias, para garantir um estabelecimento adequado do pomar e ultrapassar esta fase crítica.

A muda é um dos insumos mais importantes para a formação de um pomar de citros, tendo-se em vista o caráter perene da cultura. A importância da muda está no fato de que potencial máximo de produtividade e de qualidade das frutas será revelado 6 a 8 anos após o plantio, e a longevidade do pomar será somente conhecida em um intervalo de tempo ainda maior. E com a presença da CVC e da gomose, é muito maior o risco do plantio de pomares com mudas que não tenham sido obtidas em ambiente protegido de patógenos e insetos vetores em todas as etapas de produção e sem o uso de material propagativo livre de doenças. Por isso, é fundamental que se obtenha e conserve material de propagação sadio para se produzir mudas de alta qualidade genética e sanitária.

As características mais importantes das mudas cítricas são a origem das sementes e das borbulhas (plantas-matrizes) e a qualidade do sistema radicular. Com o objetivo de melhorar a qualidade das mudas cítrica utilizada no Estado, a Secretaria de Agricultura, instituiu o "Programa de Certificação de Mudas de Cítricas do Estado de São Paulo", que prevê a utilização de ambiente fechado, onde as mudas devem ser obtidas envasadas, com substrato e água desinfetados e materiais vegetais indexados para viroses e para a CVC (Panzani et al., 1994).

Com isso, tem se acentuado na citricultura, a tendência de produção de porta-enxertos em bandejas ou tubetes, e posteriormente, a obtenção das mudas em vasos ou sacolas plásticas, ambas com substrato isento de patógenos e em telados a prova de insetos vetores. Este sistema possibilita a obtenção das mudas de haste única em 9 a 12 meses da semeadura do portaenxerto. 
Entretanto, para a produção precoce de mudas envasadas sadias, é necessária a adequação da adubação, pois a composição do substrato e o balanço nutricional adequado são de grande importância. Um dos problemas enfrentados na produção de mudas cítricas no sistema de vasos, é o de colocar-se à disposição das culturas, no período de maior exigência, a quantidade de nutrientes necessários para o seu desenvolvimento.

O material seco de um vegetal constituí-se, aproximadamente em $90 \%$ do total, de compostos orgânicos como celulose, amido, lipídeos e proteinas, o restante são os nutrientes na forma mineral. Cada um desses nutrientes exerce funções específicas, quer seja na forma estrutural, ou na constituição ou ativação de enzimas, interferindo, dessa maneira, no metabolismo vegetal. A produção biológica ou o material orgânico produzido, está diretamente relacionado com o processo fotossintético, que é o processo primário de síntese de compostos orgânicos das plantas verdes. No entanto, para muitas culturas, não apenas a produção de material seco é importante, mas também a partição desses fotossintetados e as relações fonte-dreno, entre a parte aérea (fonte) e as raízes (dreno), que determinam alterações na morfologia das plantas.

As análises dos teores totais de nutrientes em tecidos foliares têm sido amplamente utilizadas no diagnóstico da nutrição de plantas devido à boa correlação entre a quantidade de nutrientes aplicados na cultura e o teor deles nas folhas. No entanto, os teores solúveis desses nutrientes nas folhas podem acrescentar informações na avaliação do estado nutricional da cultura, além de apresentarem-se como métodos de determinação mais rápidos.

Este trabalho teve como objetivos:

a) estabelecer as doses dos nutrientes N, P e K, para a produção de mudas de laranjeira 'Valência' sobre o porta-enxerto limoeiro 'Cravo' no sistema de vasos em viveiro com cobertura plástica e protegido com tela; 
b) avaliar os efeitos dos nutrientes N, P e K na fotossíntese e crescimento das mudas de citros;

c) determinar as exigências nutricionais dos nutrientes $N, P$ e $\mathrm{K}$ e suas relações com os demais macronutrientes nos tecidos da muda. 


\section{Revisão de Literatura}

\subsection{Produção de mudas de citros em vasos}

As modificações nos processos de produção de mudas cítricas, de acordo com Lima (1986), incluem: a propagação in vitro, a micro-enxertia, a identificação clonal através do polimorfismo do DNA e do mapeamento de isoenzimas, a pré-inoculação com fungos micorrízicos específicos para cada tipo de porta-enxerto e a produção de mudas em vasos em ambiente controlado.

De acordo com Platt \& Opitz (1973), as vantagens do sistema de produção de mudas em recipientes incluem: maior controle da infecção e da contaminação por doenças fúngicas e por nematóides; crescimento mais intenso, devido ao uso de substratos mais elaborados; maior controle da fertilidade do substrato e do ambiente e a ausência de distúrbios radiculares no transplante. Porém, os autores apresentam como desvantagens do sistema: produção de plantas menores para o transplante, as quais requerem maiores cuidados durante o primeiro ano; necessidade de replantio em um recipiente maior, quando a época de plantio prolonga-se; necessidade de coberturas com polietileno e sombreamento para controle do ambiente.

Atualmente, este sistema está sendo recomendado pela Secretaria da Agricultura do Estado de São Paulo para a produção de mudas certificadas livres da gomose e da CVC (Panzani et al., 1994).

A eficiência do sistema de produção de mudas em recipientes é alta, principalmente quando se considera o número de plantas por área. No sistema de viveiros tradicional, a população está entre 80 a 160 mil plantas por hectare, 
enquanto no sistema em vasos, tem-se em torno de 400 mil plantas por hectare (Castle \& Rouse, 1990).

Castle et al. (1979) descreveram o sistema de produção de mudas em recipientes no EUA, onde as plântulas dos porta-enxertos foram produzidas em tubetes ou em bandejas e as mudas foram enxertadas em recipientes (sacos plásticos). Nesse sistema, as plantas já estavam adequadas para a enxertia com 3 ou 4 meses e as mudas estavam prontas para o transplante com 12 meses. Castle \& Fergunson (1982) descreveram as alterações ocorridas no sistema de produção de mudas descrito anteriormente. De acordo com Teófilo Sobrinho (1991), apesar do método já estar bem difundido em países com produção citrícola, ele tinha um uso ainda restrito no Brasil. Atualmente o sistema tem tido uma grande difusão no país.

Sempionato et al. (1997) e Carvalho (1998) apresentaram e discutiram algumas estratégias e práticas culturais para a produção de mudas sadias de citros em ambiente protegido. Apesar do sistema de produção de mudas neste sistema estar difundindo-se, existe a necessidade de elucidar-se alguns componentes, como por exemplo as adubações.

\subsection{Nitrogênio, fósforo é potássio na nutrição mineral das plantas.}

$\mathrm{O}$ nitrato $\left(\mathrm{NO}_{3}{ }^{-}\right)$é a principal forma de nitrogênio disponível em ambientes oxidados e por isso a mais absorvida pelas plantas. Para ser incorporado no metabolismo vegetal, o nitrato tem que sofrer algumas transformações. A primeira reação é sua redução para nitrito $\left(\mathrm{NO}_{2}{ }^{-}\right)$, catalisada pela redutase do nitrato. A etapa seguinte é a redução do nitrito para amônio $\left(\mathrm{NH}_{4}{ }^{+}\right)$. O nitrogênio reduzido na forma de amônio pode então ser assimilado, primeiro nos aminoácidos glutamato e glutamina e, depois em outras biomoléculas que contém nitrogênio (Mengel \& Kirkby, 1982; Kato, 1986; Marschner, 1995). O nitrogênio tem um papel fundamental no metabolismo 
vegetal, uma vez que é constituinte de todas as proteínas e ácidos nucleícos da planta.

O fósforo, nos vegetais, é um componente dos fosfolipídeos da membrana, dos açúcares fosforilados e das proteínas, é também parte integrante do DNA (acido desoxiribonucleíco), RNA (ácido ribonucleico), ATP (adenosina 5-trifosfato); PEP (fosfoenolpiruvato), NADPH (nicotinamida adeninadinucleotídeo difosfato) e outros compostos bioquímicos que utilizam o fosfato como armazenamento de energia. Como vários processos metabólicos vitais dependem desse suprimento de energia, a nutrição adequada de fósforo vai interferir diretamente sobre a sintese de proteínas e de ácidos nucleicos. Ele atua também na regulação da ATP-ase, que regula o movimento de prótons pela célula (Mengel \& Kirkby, 1982; Marschner, 1995). De acordo com Natr (1972), apenas entre 1 a $2 \%$ do $P$ total das folhas está na forma de ATP.

O potássio atua na regulação do potencial osmótico das células, sendo muito importante no balanço das cargas negativas dos ácidos orgânicos dentro das células e dos ânions absorvidos pelas raízes. O acúmulo desse nutriente reduz o potencial osmótico, levando à uma redução na taxa de transpiração (Huber, 1985). O potássio é ativador de numerosas enzimas e, portanto é requerido em numerosos processos metabólicos. Sua deficiência pode acarretar no acúmulo de compostos nitrogenados livres ou solúveis. Esses compostos podem ser aminoácidos, amidas e amônia, além de aminas, que são produtos da descarboxilação de aminoácidos, como é o caso da putrescina (Mengel \& Kirkby, 1982; Marschner, 1995).

\subsection{Adubação das mudas de citros}

O programa de adubação nos viveiros de citros da Florida tem como objetivo o crescimento máximo das mudas. Este crescimento vigoroso é obtido pela aplicação de doses altas de fertilizantes (Castle \& Fergunson, 1982 e 
Williamson \& Castle, 1989). Segundo Castle \& Rouse (1990), no entanto, os fundamentos dessa prática são empíricos. A adubação dos viveiros está baseada nos mesmos princípios utilizados para as plantas de viveiros no campo (Castle \& Fergunson, 1982). As quantidades, fórmulas e freqüências utilizadas estão baseadas na experiência individual dos produtores, pois faltam publicações com recomendações especificas (Maust \& Willianson, 1994).

O estabelecimento das exigências nutricionais das plantas é a primeira aproximação para a determinação das quantidades de nutrientes necessárias para a cultura. Coetzee et al. (1993) determinaram a remoção de nutrientes por quatro porta-enxertos de citros (limoeiros 'Rugoso' e 'Volkameriano' e citranges 'Troyer' e 'Carrizo'). As plantas foram cultivadas em substrato de casca de pinus pré-enriquecido e também receberam fertirrigação. Quando os portaenxertos atingiram $0,8 \mathrm{~m}$ de altura, os autores determinaram que a extração média de nutrientes foi: $\mathrm{N}, 243 ; \mathrm{P}, 26 ; \mathrm{K}, 147$; Ca, 128; Mg, 21 e S, 25 mg planta ${ }^{-1}$. Os resultados mostraram que a extração de potássio foi equivalente à de cálcio. Castle \& Rouse (1990), na Florida, determinaram os teores de macronutrientes nas mudas de citros em viveiros no campo e no sistema de vasos e os teores médios foram, respectivamente: $N, 15,7$ e 16,9; $P, 1,3$ e 1,5; $\mathrm{K}, 10,7$ e 12,2; Ca, 12,7 e 10,9; e Mg,1,5 e 1,5 $\mathrm{g} \mathrm{kg}^{-1}$. As plantas dos viveiros no campo apresentavam em média $144,6 \mathrm{~g}$ de material seco, enquanto que as dos vasos $40,4 \mathrm{~g}$, essa diferença ocorreu devido à idade das mudas: 21 e 15 meses, respectivamente.

$\mathrm{Na}$ Florida, as mudas de citros são produzidas em vasos, em aproximadamente 18 meses, desde a semeadura dos porta-enxertos até a obtenção da muda. Os fertilizantes são aplicados com freqüência durante esse período, geralmente, através da água de irrigação (Williamson \& Castle, 1989). De acordo com Coetzee (1995), a adubação de viveiros de mudas em recipientes pode ser de quatro maneiras: pré-enriquecimento do substrato (a 
qual inclue os fertilizantes de liberação lenta), fertirrigação, adubação de cobertura e adubação foliar.

Cootzee et al. (1993) compararam as aplicaçöes foliares associadas com pré-enriquecimento, com a fertirrigação, com o objetivo de reduzir os efeitos da salinidade nos substratos. Os resultados mostraram que as aplicações foliares com macronutrientes (N, P, K, Ca, Mg e S) não substituíram a fertirrigação. No entanto, o pré-enriquecimento com calcário dolomítico e superfosfato, e as aplicações foliares com esses 6 nutrientes podem ser utilizadas para substituir a fertirrigação. Nesse estudo, o tratamento padrão foi a fertirrigação com uma solução contendo $250 \mathrm{mg} \mathrm{N}, 25 \mathrm{mg} \mathrm{P}$ e $200 \mathrm{mg} \mathrm{K} \mathrm{por} \mathrm{dm}{ }^{3}$. Castle e Rouse (1990) relataram que as melhores doses na aplicação de fertilizantes via água de irrigação nas mudas após a enxertia, no sistema de vasos, foram em média: N, 3,2; P, 0,55 e K, 1,8 g por planta.

O nível crítico de nitrogênio para diversas espécies de porta-enxertos e para plantas jovens enxertadas estão entre 10 e $25 \mathrm{mg} \mathrm{L}^{-1}$ (Chapman \& Liebig, 1937 e Maust \& Williamson, 1991). Nestes experimentos, a solução contendo nitrogênio foi aplicada continuamente, sem considerar, no entanto, a quantidade do nutriente aplicado por todo período. Os resultados de Maust \& Williamson (1991) indicaram que 120 a $140 \mathrm{mg}$ de $\mathrm{N}$ por planta por semana foram suficientes para manter o crescimento das plantas, enquanto que aplicações menores que $50 \mathrm{mg}$ de $\mathrm{N}$ por semana limitaram a taxa de crescimento.

Chapman \& Rayner (1951), em um estudo de 9 anos com laranjeira 'Washington Navel' em solução nutritiva, observaram que os sintomas de deficiência de fósforo estavam associados ao nível de $3 \mathrm{mg} \mathrm{L}^{-1}$, o nível crítico foi de $12 \mathrm{mg} \mathrm{L}^{-1}$, e que níveis próximos a $150 \mathrm{mg} \mathrm{L}^{-1}$ não reverteram-se em crescimento ou aumento dos teores foliares. 
Existem ainda as preocupações ambientais, devido ao uso de doses cada vez maiores de fertilizantes. Nos viveiros da Flórida, esses aumentos podem ser comprovados Castle \& Rouse (1990), com base em relatos anteriores de Bridges \& Youtsey (1977) de que as aplicações anuais de N e K dobraram nesse período, e estavam em torno de 1000 a $2000 \mathrm{~kg} \mathrm{ha}^{-1}$.

Estudos realizados com fornecimento de fertilizantes aos porta-enxertos até o ponto de repicagem têm demonstrado benefícios. A suplementação com fertilizantes contendo $\mathrm{P}$ e $\mathrm{Ca}$ no meio de cultivo tem efeito comprovado no aumento do desenvolvimento das plantas cultivas em solo (Bueno \& Souza, 1989) ou tubetes com substrato (Carvalho \& Souza, 1988), tendo sido relatadas respostas ao $\mathrm{P}$ até a dose de $5120 \mathrm{~g} \mathrm{~m}^{-3}$ de $\mathrm{P}_{2} \mathrm{O}_{5}$. Carvalho (1994) observou que aplicações de uma solução de $\mathrm{KNO}_{3}\left(4,5 \mathrm{~g} \mathrm{~L}^{-1}\right)$ via água de irrigação proporcionou respostas positivas no crescimento dos porta-enxertos 'Cravo' e 'Cleópatra'. Aplicações de soluções de $\mathrm{KNO}_{3}$ e $\mathrm{NH}_{4} \mathrm{H}_{2} \mathrm{PO}_{4}\left(5\right.$ e $\left.10 \mathrm{~g} \mathrm{~L}^{-1}\right)$ a cada 13 dias proporcionaram a obtenção de porta-enxertos de limoeiro 'Cravo' com ganhos de $50 \%$ no peso seco total e $40 \%$ nas raízes e redução de $25 \%$ no tempo da repicagem (DeCarlos Neto et al., 1994).

Após o transplantio, ainda durante a fase inicial de crescimento o portaenxerto, existem respostas a niveis de $P$ no substrato muito superiores aos normalmente observados no solo (Resende et al., 1995), sendo observadas respostas positivas até $2,2 \mathrm{~kg} \mathrm{~m}^{-3}$ de $\mathrm{P}_{2} \mathrm{O}_{5}$.

\subsection{Diagnose foliar}

A análise dos tecidos vegetais é baseada no princípio de que a concentração de um elemento ou nutriente na planta, ou em uma de suas partes, é resultado de todos os fatores que agiram e interagiram, afetando o crescimento da planta, incluindo a disponibilidade do elemento (Malavolta et 
al., 1989). As folhas, como são a sede da maioria dos processos fisiológicos vegetais, geralmente são $o$ órgão que melhor reflete o estado nutricional das plantas. As premissas da análise foliar são a existência de relações significativas entre o suprimento de nutriente e os teores deles nas folhas e que isso, por sua vez, está associado com as produções.

A utilização da análise de folhas como uma ferramenta para avaliar o estado nutricional da cultura dos citros foi discutida por Smith (1966), Embleton et al. (1973) e, no Brasil, por Malavolta (1992). As classes de teores foliares de nutrientes para o Estado de São Paulo é fornecido pelo Grupo Paulista de Adubação e Calagem dos Citros (GPACC, 1994). 


\section{CRESCIMENTO E PRODUÇÃO DE MATERIAL SECO DE MUDAS DE CITROS CULTIVADAS EM VASOS EM FUNÇÃO DA ADUBAÇÃO COM NITROGÊNIO, FÓSFORO E POTÁSSIO.}

\section{Resumo}

Cultivou-se em ambiente protegido mudas de laranjeira 'Valência' (Citrus sinensis L. Osbeck) sobre porta-enxerto de limoeiro 'Cravo' (C. limonia Osbeck) em vasos com capacidade para 3,8 L com substrato a base de casca de pinus. Avaliou-se os efeitos do fornecimento dos nutrientes $N, P$ e $K$, sobre o crescimento do porta-enxerto e das mudas. Utilizou-se um esquema fatorial fracionário (1/5) $5^{3}$ com um delineamento em 5 blocos casualisados. Os tratamentos ( $\mathrm{g}$ por planta ${ }^{-1}$ ) consistiram em 5 doses de $\mathrm{N}: 1,25 ; 6,25 ; 11,25$; 16,$25 ; 21,25 ; 5$ doses de $\mathrm{K}: 0,42 ; 3,75 ; 6,22 ; 9,34 ; 12,45$ e 5 doses de P: 0,19 ; 0,$89 ; 1,59 ; 2,29 ; 2,99$. $\mathrm{N}$ e $\mathrm{K}$ foram fornecidos semanalmente, sendo $37,5 \%$ da dose aplicada na produção do porta-enxerto e $62,5 \%$ após a enxertia. O P foi fornecido todo no plantio do porta-enxerto. Avaliou-se a produção de material seco das folhas, raízes, caule, parte aérea e total; área foliar, relação raízes/parte aérea; altura de plantas; volume radicular, relação área foliar/material seco para os porta-enxertos e as mudas, e o diâmetro do caule para os porta-enxertos. Funçães de resposta foram ajustadas e os níveis de nutrientes foram calculados. Para a produção das mudas, as doses de $\mathrm{N}$ e K, calculadas a partir da área foliar foram sempre maiores que aquelas que 
somente consideram a produção de material seco total. Isso foi observado tanto na produção dos porta-enxertos de limoeiro 'Cravo', como das mudas de laranjeira 'Valência'l'Cravo'.

\section{CONTAINEREZED CITRUS NURSERY TREES GROWTH AND DRY MATTER PRODUCTION DUE TO NITROGEN, PHOSPHORUS AND POTASSIUM FERTILIZATION.}

\section{Summary}

'Valencia' sweet orange nursery trees (Citrus sinensis L. Osbeck) budded on Rangpur lime rootstocks ( $C$. limonia Osbeck) were grown in a protected environment in 3,8L containers with Pinus bark, vermiculite and perlite substract. NPK fertilization effect were evaluated. The experiment was carried out as a (1/5) $5^{3}$ factorial in a complete randomized block design. Treatments comprised (g per plant) five levels of $\mathrm{N}: 1.25 ; 6.25 ; 11.25 ; 16.25 ; 21.25$; five levels of $\mathrm{K}: 0.42 ; 3.75 ; 6.22 ; 9.34 ; 12.45$; and five levels of $\mathrm{P}: 0.19 ; 0.89 ; 1.59$; $2.29 ; 2.99$. Nitrogen and $K$ were applieded weekly, and $37.5 \%$ of the total fertilization was applied to rootstocks. All $P$ was supplied at planting. Leaves, root, stem, shoot and total dry matter production, shoot/root ratio, leaf area, plant height, root system volume; leaf area dry matter ratio rootstocks and nursery trees and rootstock stem diameter were evaluated. Response functions were adjusted and nutrient rates for maximum yield are presented. Nitrogen and $K$ fertilizers levels calculated by leaf area were always greater than those obtainned by dry matter production. This was observed at 'Valência' sweet orange production and also at 'Rangpur lime' production. 


\subsection{Introdução}

A produção mudas de citros em ambiente protegido é uma alternativa ao sistema tradicional de produção de viveiros a campo. O sistema propõe a produção sob casa-de-vegetação onde os porta-enxertos são cultivados em tubetes com diferentes substratos, com posterior transplantio para vasos maiores para realização da enxertia e formação da muda (Carvalho, 1998). O objetivo é melhorar as condições fitossanitárias, promover um crescimento mais intenso e padronizar o processo de formação das mudas. No entanto, nesse sistema de produção ocorre um grande crescimento das plantas em um curto espaço de tempo e em um espaço reduzido para o desenvolvimento do sistema radicular (Carvalho, 1994). Portanto, o fornecimento de nutrientes em doses adequadas e balanceadas é necessário para estimular o crescimento máximo e para que as perdas por lixiviações sejam evitadas.

A produção de mudas citricas em vasos e em ambiente protegido vem sendo utilizada na Flórida (EUA) desde 1977, mas ainda existe grande variação nas doses e freqüências de aplicação de fertilizantes. As adubações nitrogenadas são aplicadas com base em dosagens utilizadas em viveiros no campo devido à ausência de recomendações na literatura (Castle \& Fergunson, 1982 e Maust \& Williamson, 1994).

No Brasil, os estudos realizados com o fornecimento de fertilizantes contendo N, P e K ao limoeiro 'Cravo' até o ponto de repicagem ou transplantio para os vasos definitivos têm-se mostrado benéficos, pois obteve-se redução do tempo de formação e aumento da produção de material seco das plantas (Carvalho \& Souza, 1988; Carvalho, 1994 e DeCarlos Neto et al., 1994). Após o transplante, durante a fase inicial de crescimento do porta-enxerto, existe resposta ao $\mathrm{P}$ no substrato muito superiores aos normalmente observados no solo, sendo observadas respostas positivas até $2,2 \mathrm{~kg} \mathrm{~m}^{-3}$ de $\mathrm{P}$ (Resende et al., 1995). 
Pesquisas têm mostrado que os nutrientes interferem no crescimento das plantas, mas é necessário estabelecer as doses adequadas para tornar a produção economicamente viável e maximizar o crescimento, pois os desbalanços nutricionais podem acarretar em prejuízos à muda, alterando sua morfologia. Existem estudos mostrando que doses elevadas de $\mathrm{N}$ podem ser prejudiciais ao desenvolvimento radicular (Ford et al., 1957; Smith, 1965 e Witt, 1997) e alteram a relação entre as raízes e a parte aérea (Marschner, 1995).

Outro fator que deve ser considerado é que, na cultura dos citros, o crescimento das raízes e da parte aérea segue um ritmo alternado. Bevington \& Castle (1985) determinaram que nas plantas jovens de citros, mesmo quando a temperatura e a umidade do solo não são fatores limitantes, o crescimento das raízes é cíclico, alternando-se com o crescimento da parte aérea. Observaram em plantas de laranjeira 'Valência' sobre limoeiro 'Rugoso' e citrange 'Carrizo', que a redução no crescimento do sistema radicular ocorreu na mesma proporção do aumento da taxa de crescimento da parte aérea. Essa situação fica mais evidenciada após a enxertia, quando faz-se o forçamento da borbulha do enxerto e sua brotação de folhas restitui a parte área da planta. Nesse momento, a variedade copa enxertada tem prioridade e seu crescimento ocorre em detrimento do crescimento das raizes (Castle, 1978). Isso ocorre, pois as raízes e a parte aérea competem por água, nutrientes e carbono (Castle, 1978 e Syvertsen \& Lloyd, 1994) e pelas reservas de nitrogênio (Legaz et al., 1982). Além da água e dos nutrientes, os fitoreguladores (citocininas e ácido abscísico) e outros metabólitos também exercem um papel importante na relação raízes I parte aérea dos citros (Syvertsen \& Lloyd, 1994 e Witt, 1997).

O objetivo deste trabalho foi avaliar o efeito da adubação com NPK sobre o crescimento e produção de matéria seca do porta-enxerto limoeiro 'Cravo' e das mudas de laranjeira 'Valência'l'Cravo' produzidas em vasos sob ambiente protegido. 


\subsection{Material e Métodos}

O experimento foi conduzido em viveiro demonstrativo do sistema de produção de mudas certificadas de citros, no Centro de Citricultura "Sylvio Moreira", do Instituto Agronômico - IAC, em Cordeirópolis-SP. O viveiro é coberto por um filme plástico transparente e com telado contra afídeos nas laterais. As bancadas para a produção de mudas são elevadas em $0,3 \mathrm{~m}$ do solo (Carvalho \& Laranjeira, 1994). Utilizou-se o substrato comercial Rendimax, composto de casca de Pinus, vermiculita e perlita da Empresa Eucatex Ltda, que apresentou as seguintes características químicas: $P$ (resina) $48,1 \mathrm{mg} \mathrm{dm}^{3}$; M.O. 731,7 $\mathrm{g} \mathrm{dm}^{3} ; \mathrm{pH}\left(\mathrm{CaCl}_{2}\right)$ 5,2; K 2,8; Ca 18,8; $\mathrm{Mg} \mathrm{19,5;} \mathrm{H+Al} \mathrm{27,2;} \mathrm{S} \mathrm{41,1;}$ T 68,3 mmol $_{c}$ dm $^{-3}$; V 60,2\%; Cu 0,4; Fe 13,6; Mn 17,1 e Zn 1,4 mg dm ${ }^{-3}$.

\subsubsection{Delineamento experimental}

No experimento foi utilizado um esquema fatorial fracionário (1/5) $5^{3} \mathrm{com}$ 5 blocos ao acaso (com um total de 25 tratamentos) conforme Conagin \& Jorge (1982). A distribuição utilizada foi: bloco I, tratamentos 111, 254, 342, 435 e 523; no bloco II, os tratamentos 134, 222, 315, 453 e 541; bloco III, 152, 245, 333, 421 e 514; bloco IV, 125, 213, 315, 444 e 532; e bloco V, 143, 213, 324, 412 e 555 (os números dos tratamentos indicam as doses de $\mathrm{N}, \mathrm{P}$ e $\mathrm{K}$, respectivamente).

\subsubsection{Tratamentos}

O $P$, na forma de superfosfato triplo $\left(78,6 \mathrm{~g} \mathrm{~kg}^{-1} \mathrm{P}\right)$, foi aplicado totalmente no plantio e homogeneizado com o substrato. Fornecendo-se as seguintes doses (g por planta) de 0,$19 ; 0,89 ; 1,59 ; 2,29$; e 2,99 . O N e O K foram parcelados durante 40 semanas, em soluções de $\mathrm{NH}_{4} \mathrm{NO}_{3}\left(330 \mathrm{~g} \mathrm{~kg}^{-1}\right.$ de $\mathrm{N})$ e $\mathrm{KCl}\left(497,9 \mathrm{~g} \mathrm{~kg}^{-1}\right.$ de $\left.\mathrm{K}\right)$, respectivamente. As mudas receberam: 1,25; 6,25; 11,$25 ; 16,25$ e 21,25 g por planta de $\mathrm{N}$ e 0,41; 3,75; 6,22; 9,34 e 12,45 g por planta de $\mathrm{K}$. Os níveis mais baixos de $\mathrm{P}$ e $\mathrm{K}$ correspondem aos niveis presentes no substrato. Os porta-enxertos receberam $35,7 \%$ das doses de $N(0,47 ; 2,34$; 
$4,22,6,09$ e $7,97 \mathrm{~g}$ por planta) e de $\mathrm{K}(1,41 ; 2,33 ; 3,50$ e 4,67g por planta) o restante sendo fornecido após a enxertia. Foi realizada uma aplicação de $\mathrm{CaCO}_{3}$ e de $\mathrm{CaSO}_{4}$ nas doses de 0,34 e $0,9 \mathrm{~g} \mathrm{dm}^{-3}$ de substrato, respectivamente. Os micronutrientes foram fornecidos através de pulverizações mensais nas seguintes dosagens $\left(\mathrm{g} \mathrm{L}^{-1}\right)$ : $\mathrm{B}, 0,2 ; \mathrm{Mn}, 0,5$ e $\mathrm{Zn}, 0,6$.

\subsubsection{Instalação e condução}

A instalação e condução das plantas baseou-se nas recomendações de Carvalho (1998). Os porta-enxertos de limoeiro 'Cravo' (Citrus limonia Osbeck) foram semeados em tubetes de $50 \mathrm{~cm}^{3}$ e transplantado aos 4 meses para vasos com capacidade para $3,8 \mathrm{~L}$, quando iniciaram os tratamentos. Após 4 meses de cultivo, realizou-se a enxertia em " $T$ " invertido com borbulhas de laranjeira 'Valência' (Citrus sinnensis L. Osbeck), e o amarrio foi realizado com fitilho plástico. Aos 20 dias após a enxertia foi realizado o forçamento da brotação da borbulha através da decapitação do porta-enxerto acima da enxertia, por ocasião da retirada do fitilho. As mudas foram conduzidas até o ponto de muda de haste única, 6 meses após a enxertia.

Avaliou-se a produção de material seco das folhas, raizes, caule, parte aérea e total (g por planta); área foliar $\left(\mathrm{cm}^{2}\right)$, relação raízes/parte aérea; altura de plantas $(\mathrm{cm})$; volume radicular $\left(\mathrm{cm}^{3}\right)$, e a relação área foliar/material seco das folhas e total $\left(\mathrm{cm}^{2} \mathrm{~g}^{-1}\right)$ dos porta enxertos e das mudas, o diâmetro do caule na altura de enxertia $(\mathrm{mm})$ para o porta-enxerto e o comprimento dos surtos vegetativos de crescimento $(\mathrm{cm})$ das mudas.

\subsubsection{Análise estatística}

A análise de variância foi realizada para todos os parâmetros avaliados, em função das doses dos nutrientes. Foram ajustadas funções de resposta do tipo $Y=\gamma_{0}+\gamma_{1} N+\gamma_{2} N^{2}+\gamma_{3} P+\gamma_{4} P^{2}+\gamma_{5} K+\gamma_{6} K^{2}+\gamma_{7} N P+\gamma_{8} N K+\gamma_{9} P K$, onde $Y$ 
é a variável dependente, $\gamma$ os coeficientes da regressão e N,P e K as doses utilizadas dos nutrientes (Tabelas 1 e 2). As análises estatísticas foram realizadas utilizando o programa estatístico SAS (SAS Institute, 1996). Quando as respostas foram significativas apenas para 1 ou 2 nutrientes, as funções foram simplificadas, considerando-se os níveis menores dos demais nutrientes. Determinou-se as doses dos nutrientes que proporcionaram as maiores produções através do cálculo $d x / d y=0$. Estudou-se as correlações ( $r$ ) entre os parâmetros avaliados. 


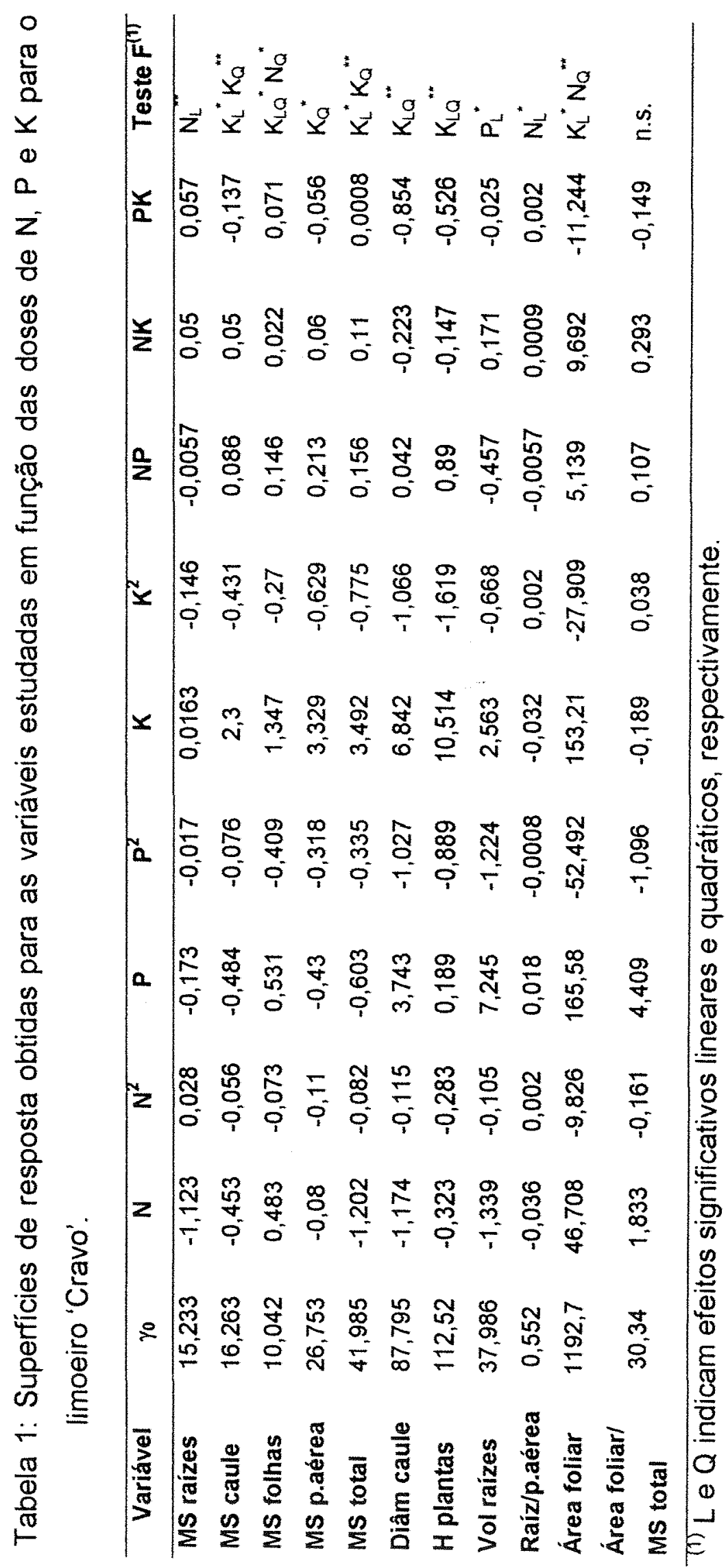




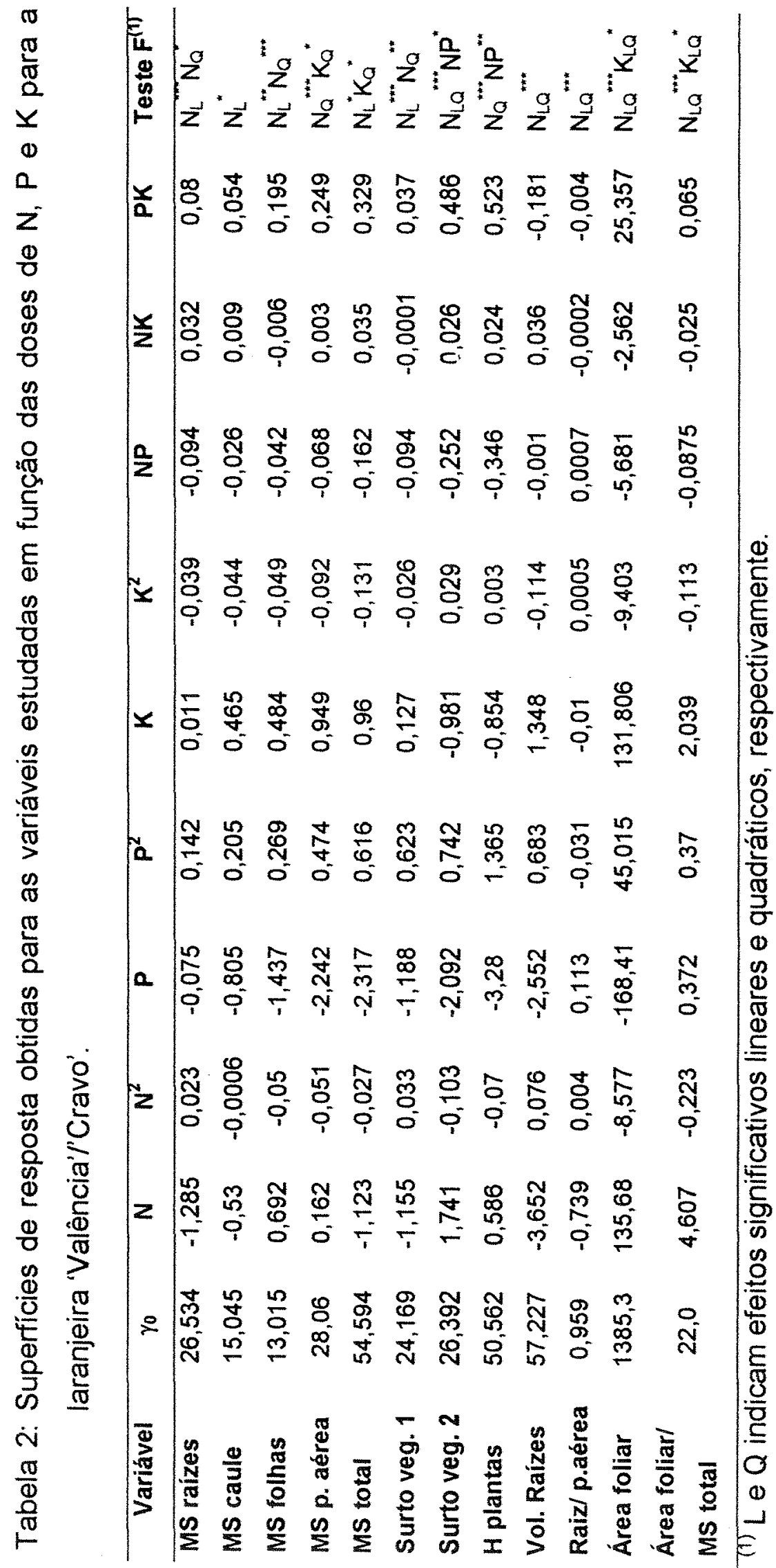




\subsection{Resultados e Discussão}

Os valores máximos da produção de material seco do caule, parte aérea e total do porta-enxerto limoeiro 'Cravo' foram 19,01; 31,07 e 45,32 g por planta, nas doses de 2,67; 2,66; e 2,29 g por planta de K (Figura 1A). Na África do Sul, Miller et al. (1993), trabalhando com 5 porta-enxertos de citros também obtiveram aumentos na produção do material seco total das plantas com o fornecimento de $\mathrm{K}$ na solução nutritiva até uma dose intermediária (150 $\mathrm{mg} \mathrm{L}^{-1}$ ) entretanto, quando elevaram a dose para $300 \mathrm{mg} \mathrm{L}^{-1}$ não houve resposta.

Na produção de folhas houve uma interação entre $\mathrm{N}$ e $\mathrm{K}$ (Figura 1B). $\mathrm{A}$ produção máxima de material seco de folhas $(12,95 \mathrm{~g}$ por planta) foi obtida com as doses de 3,96 e 2,66 g por planta, de $\mathrm{N}$ e de $\mathrm{K}$, respectivamente. Essa interação nas folhas pode ser explicada analisando-se o trabalho de Moorby \& Besford (1983), que mostraram existir relações positivas entre crescimento das folhas, fotossíntese e fornecimento de $\mathrm{K}$. Além disso, como o $\mathrm{N}$ é constituinte de todas as proteinas, atua diretamente sobre o crescimento e metabolismo vegetal.

$\mathrm{O}$ aumento nas doses de $\mathrm{N}$ interferiu negativamente na produção de material seco das raízes em ambas as avaliações. Nas Figuras $1 \mathrm{C}$ e $2 \mathrm{~A}$ podese observar que houve decréscimos de 14,7 a 8,2 g para o limoeiro 'Cravo' e de 24,9 a 9,2 g para a laranjeira 'València'/'Cravo', das doses menores $(0,47$ e 1,25 $\mathrm{g}$ por planta de $\mathrm{N}$ ) para as maiores $(7,97$ e $21,25 \mathrm{~g}$ por planta de $\mathrm{N})$. Esses resultados estão de acordo com os obtidos por Ford et al. (1957) e Smith (1965), que também observaram reduções no sistema radicular de plantas cítricas, com a utilização de doses elevadas de $\mathrm{N}$. Isso pode ser considerado um mecanismo de adaptação das plantas para aumentar o volume de solo ou substrato explorado pelas raízes. 

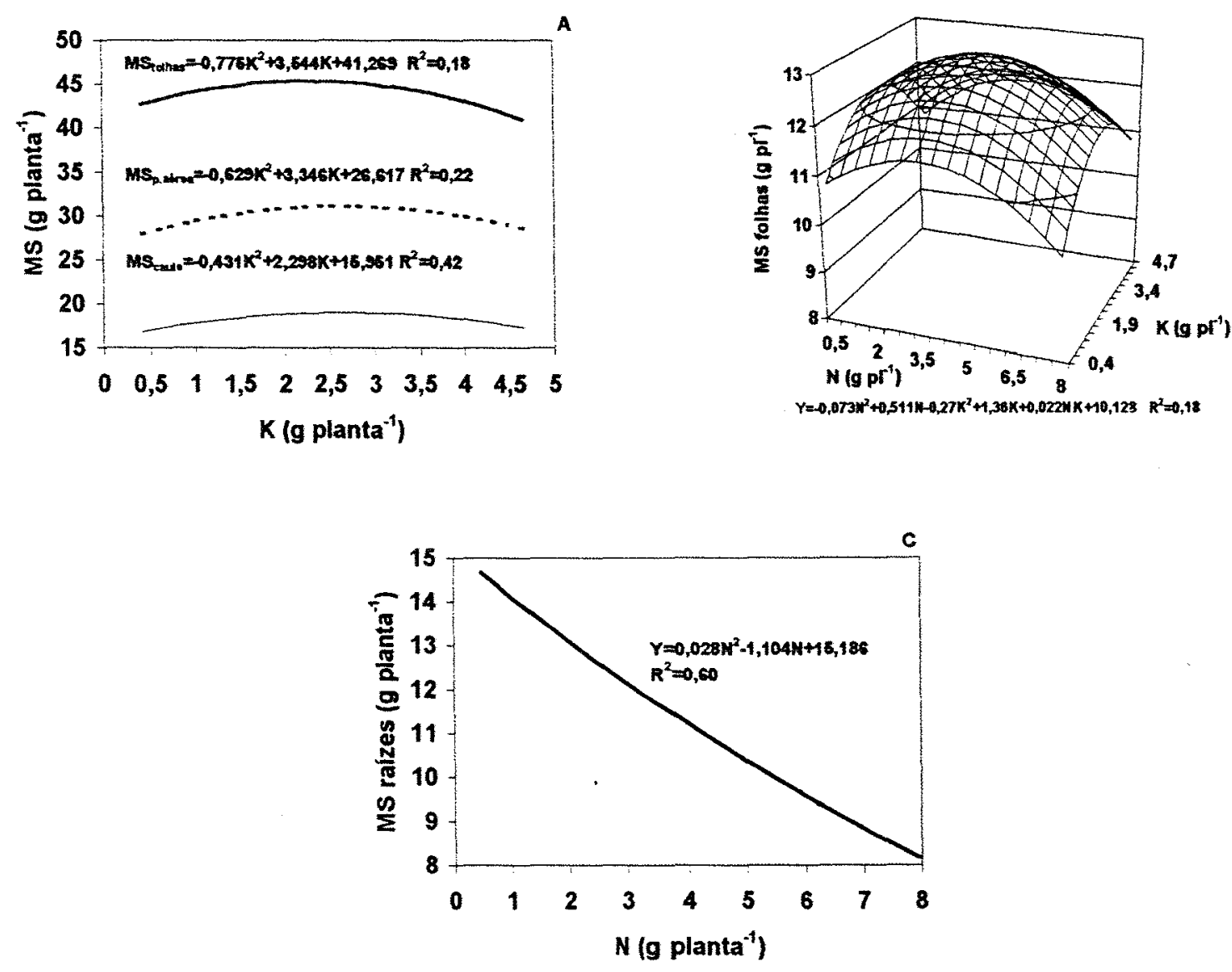

Figura 1: Produção de material seco do limoeiro 'Cravo' na época da enxertia: caule, parte aérea e total $(A)$, folhas $(B)$ e raízes $(C)$.

A Figura 2 A mostra que a produção de material seco das folhas da laranjeira 'Valência' variou de forma quadrática ao fornecimento de $\mathrm{N}$. Na dose de $1,25 \mathrm{~g}$ por planta a produção foi de $13,63 \mathrm{~g}$ e a produção máxima de $14,77 \mathrm{~g}$ foi obtida com a dose de $6,02 \mathrm{~g}$ por planta. Na produção de material seco da parte aérea e total das mudas (Figura $2 \mathrm{~B}$ e $2 \mathrm{C}$ ) houve interação entre $\mathrm{N}$ e $\mathrm{K}$, e as produções máximas (30,76 e 56,42 g por planta) foram obtidas com 1,62 e 2,47 g por planta de $\mathrm{N}$ e 5,44 e $4,23 \mathrm{~g}$ por planta de $\mathrm{K}$. 

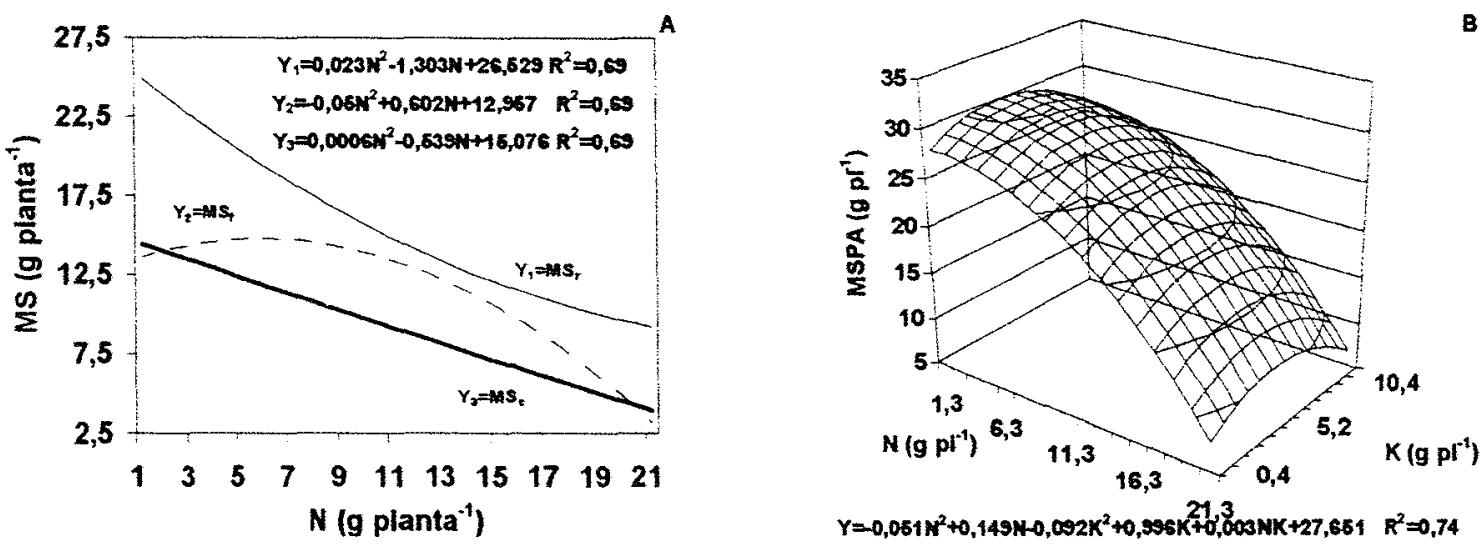

$Y=0,051 K^{2}+0,149 \%-0,002 K^{2}+0,996 K+0,003 N K+27,651 \quad R^{2}=0,74$

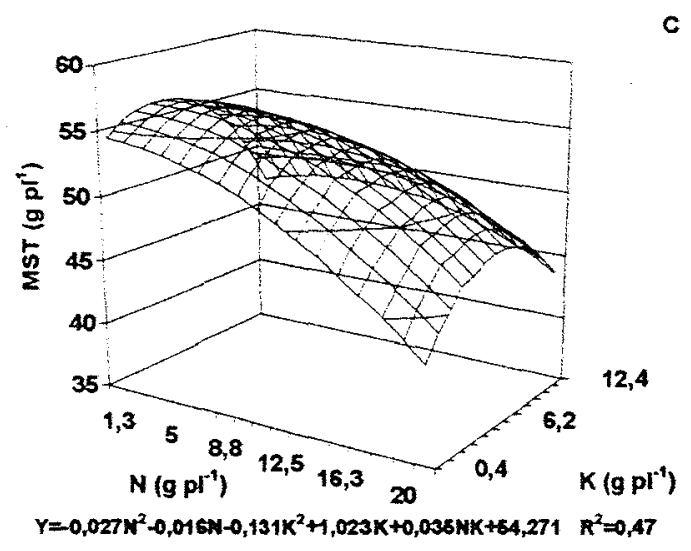

Figura 2: Produção de material seco das mudas de laranjeira 'Valência'r'Cravo', 6 meses após a enxertia: raízes, caule e folhas $(A)$, parte aérea $(B)$ e total $(C)$.

O diâmetro do caule é a característica morfológica do porta-enxerto que determina a possibilidade de realização da enxertia. Este parâmetro e a altura de plantas correlacionaram-se direta e significativamente, com um $r=0,65^{* * *}$. Os resultados obtidos para o limoeiro 'Cravo', mostram um efeito quadrático das doses de $\mathrm{K}$ sobre a altura (Figura $3 \mathrm{~A}$ ) e diâmetro do caule (Figura $3 \mathrm{~B}$ ). Houve variações no diâmetro de 99,21 a 95,35 mm, obtidos com as doses de $\mathrm{K}$ mais baixa e mais alta $(0,42$ e 4,67 g por planta, respectivamente), e o maior diâmetro $(98,03 \mathrm{~mm})$ foi obtido com a dose de $3,08 \mathrm{~g}$ por planta. Os resultados 
de altura de plantas variaram de 116,38 a $125,32 \mathrm{~cm}$, com a altura máxima $(128,84 \mathrm{~cm})$ obtida com a dose de $3,19 \mathrm{~g}$ por planta.
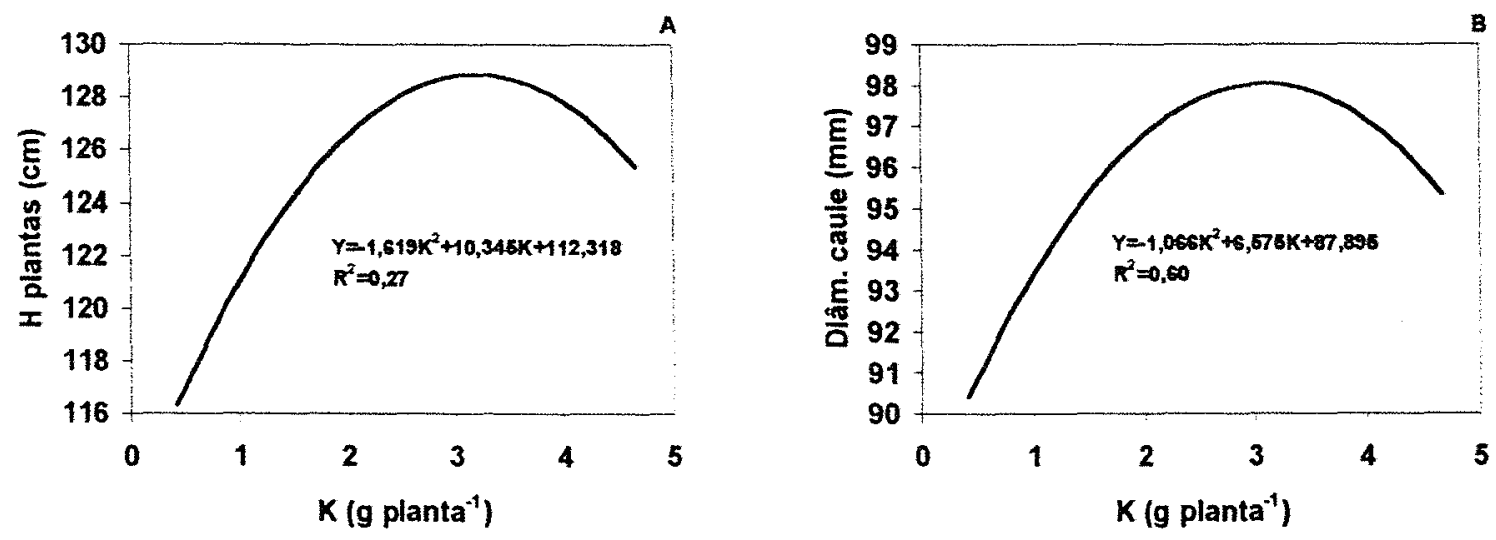

Figura 3: Altura das plantas (A), diâmetro do caule na altura de enxertia (B) do limoeiro 'Cravo', na época da enxertia.

Após a enxertia, uma causa freqüente do atraso na formação da muda cítrica é a interrupção do surto vegetativo da borbulha. Para a formação da muda, o enxerto pode necessitar de até 3 surtos de crescimento, entretanto, o ideal é que a muda esteja pronta com um único surto, uma vez que cada interrupção no crescimento pode atrasar a formação da muda. Araújo \& Souza (1994) observaram que mudas formadas com 2 surtos de crescimento atingiram a altura de desponte $(60 \mathrm{~cm}) 2,5$ meses mais tarde que as mudas formadas em um único surto. 

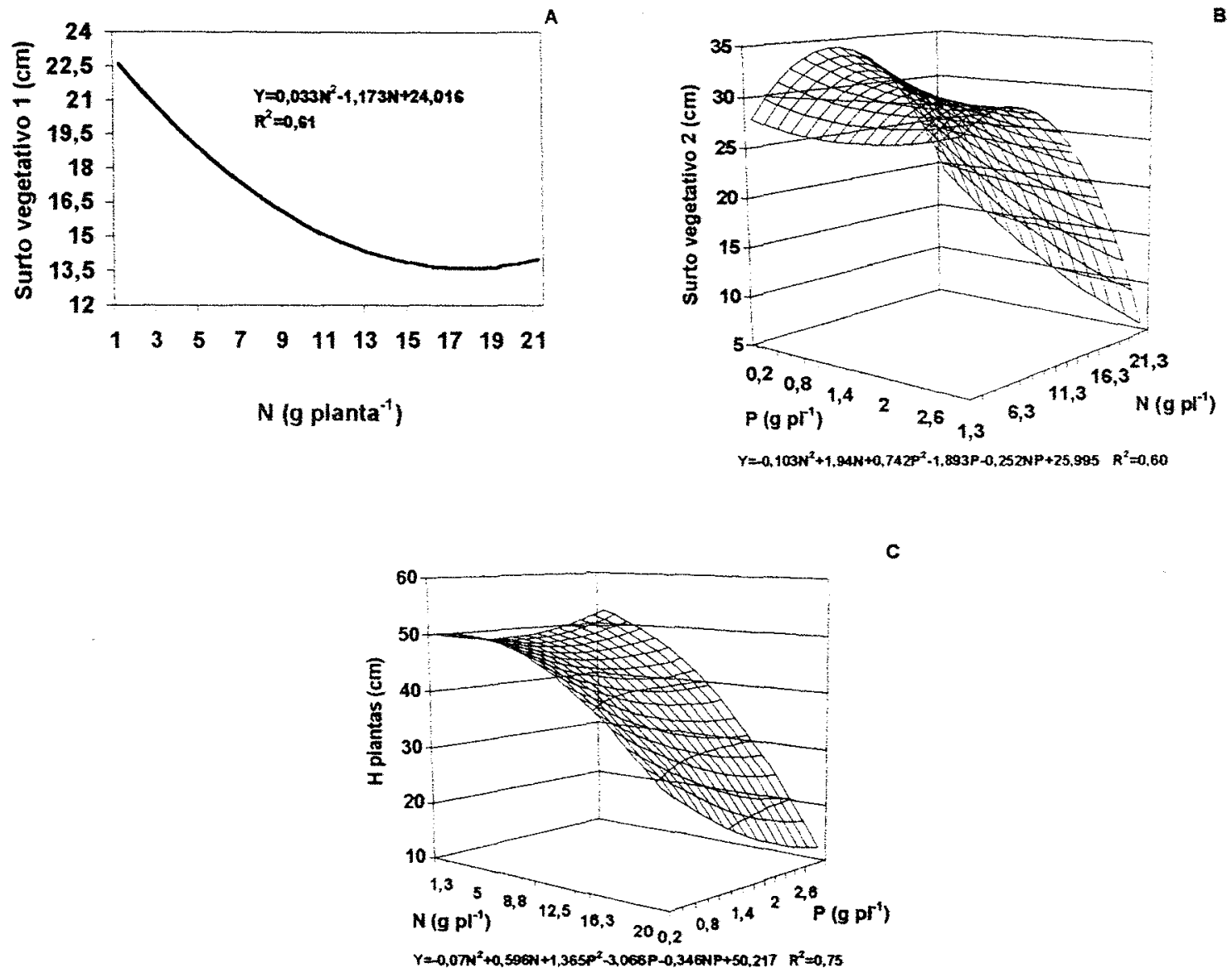

Figura 4: Comprimento dos surtos vegetativos $1(A)$ e $2(B)$, altura das plantas (C) de mudas de laranjeira 'Valência'/'Cravo', 6 meses após a enxertia.

Neste estudo, foram gastos 14 meses para a produção da muda desde a semente, o crescimento da brotação da borbulha ocorreu em 2 surtos vegetativos, provavelmente devido às altas temperaturas observadas após a enxertia, realizada no mês de janeiro. De acordo com Carvalho (1998), este fator climático pode paralisar o crescimento e reduzir o pegamento das borbulhas. Quando as plantas iniciaram o primeiro surto vegetativo (Figura $4 \mathrm{~A}$ ), observou-se que o nitrogênio influenciou negativamente, sendo que o maior 
crescimento $(22,6 \mathrm{~cm})$ foi obtido com a menor dose de $\mathrm{N}(1,25 \mathrm{~g}$ por planta). $\mathrm{Na}$ dose mais elevada $(21,25 \mathrm{~g}$ por planta) o comprimento do surto foi $13,99 \mathrm{~cm}$. Já no segundo (Figura 4 B), obteve-se uma interação entre $N$ e $P$, respectivamente, observando-se um crescimento maior nas doses de 4,24 e 1,54 g por planta de $\mathrm{N}$ e de P. Graff et. al. (1994), em viveiro de campo, não observaram efeitos das pulverizações foliares com N, Mg, S, Zn, Mn e B sobre o comprimento e o diâmetro das brotações de laranjeiras 'Valência' e 'Pera' sobre limoeiro 'Cravo', porém o ponto de desponte foi atingido em um único surto de crescimento.

Analisando-se a altura final das mudas (Figura $4 \mathrm{C}$ ) observa-se também, a interação entre $N$ e de $P$, sendo que as plantas mais altas $(52,6 \mathrm{~cm})$ foram obtidas com as doses de 1,25 e 2,99 g por planta de $\mathrm{N}$ e $\mathrm{P}$, respectivamente. $\mathrm{O}$ segundo crescimento foi mais intenso que o primeiro e relacionou-se mais com a altura final das plantas (na Tabela $3, r=0,90^{* * *}$ e $0,71^{* * *}$, respectivamente).

A determinação da área foliar é importante, porque as folhas são as principais responsáveis pela captação da energia solar e pela produção de material orgânico através da fotossíntese. Os resultados obtidos mostraram que houve uma interação entre os nutrientes $\mathrm{N}$ e $\mathrm{K}$ na área foliar, tanto no portaenxerto (Figura $5 \mathrm{~A}$ ), quanto na muda (Figura $5 \mathrm{~B}$ ). As áreas foliares máximas $\left(1578,8\right.$ e $\left.2251,4 \mathrm{~cm}^{2}\right)$ foram obtidas com 4,11 e 6,90 g por planta de $\mathrm{N} \mathrm{e} \mathrm{3,42} \mathrm{e}$ 6,32 g por planta de K, para o limoeiro 'Cravo' e a laranjeira 'Valência', respectivamente. No entanto, Reese \& Koo (1975) trabalhando com plantas com 5 anos de 'Hamlim', 'Pineapple' e 'Valência' sobre porta-enxerto de limoeiro 'Rugoso' em solos arenosos da Flórida, observaram que os aumentos na superfície foliar relacionaram-se com as aplicações de $\mathrm{N}$, mas não com as de $\mathrm{K}$. Maust \& Willianson (1994) trabalhando com mudas observou as maiores áreas foliares nos níveis intermediários de $\mathrm{N}$. 


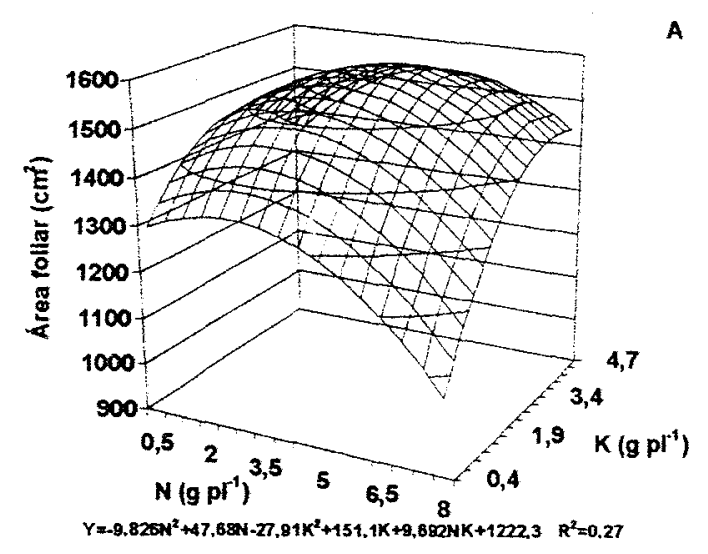

Figura 5: Área foliar do limoeiro 'Cravo' (A) e da muda de laranjeira 'Valência'/'Cravo' (B).

A relação raízes/parte aérea é útil para estudar-se o equilíbrio entre os órgãos, devido às modificações no ambiente, uma vez que indica a existência de uma interdependência entre os órgãos no balanço por água, nutrientes e carbono. Marschner (1995) e Witt (1997) afirmaram que o $N$ interfere diretamente nesse balanço, alterando a morfologia da planta. Quando há baixa disponibilidade do nutriente, há um menor crescimento da parte aérea e as raízes são longas e sem divisões. Nos níveis intermediários, há um desenvolvimento e divisão adequados do sistema radicular. No excesso do nutriente, observam-se excesso de divisão das raízes, porém o sistema radicular é reduzido e há uma estímulo para o desenvolvimento da parte aérea.

O papel do $\mathrm{N}$ no balanço entre o sistema radicular e a parte aérea da muda também pode ser evidenciado, analisando-se a relação raízes/parte aérea. A Figura 6 A ilustra essa relação até o momento da enxertia, na fase de crescimento do limoeiro 'Cravo'. Pode-se observar que o $N$ atuou negativamente sobre a relação, sendo que a relação máxima $(0,54)$ foi obtida na menor dose de $N(0,47 \mathrm{~g}$ por planta). Aumentando-se a dose até $7,97 \mathrm{~g}$ 
ocorreu uma redução na relação para 0,39. Após a enxertia (Figura $6 \mathrm{~B}$ ), o $\mathrm{N}$ continuou a interferir nessa relação, porém houve um efeito quadrático das doses do nutriente e, o ponto onde obteve-se a relação mínima $(0,63)$ foi com a dose de $9,25 \mathrm{~g}$. Nas doses mínima e máxima $(1,25$ e 21,25 g) a relação variou de 0,89 até 1,21 .
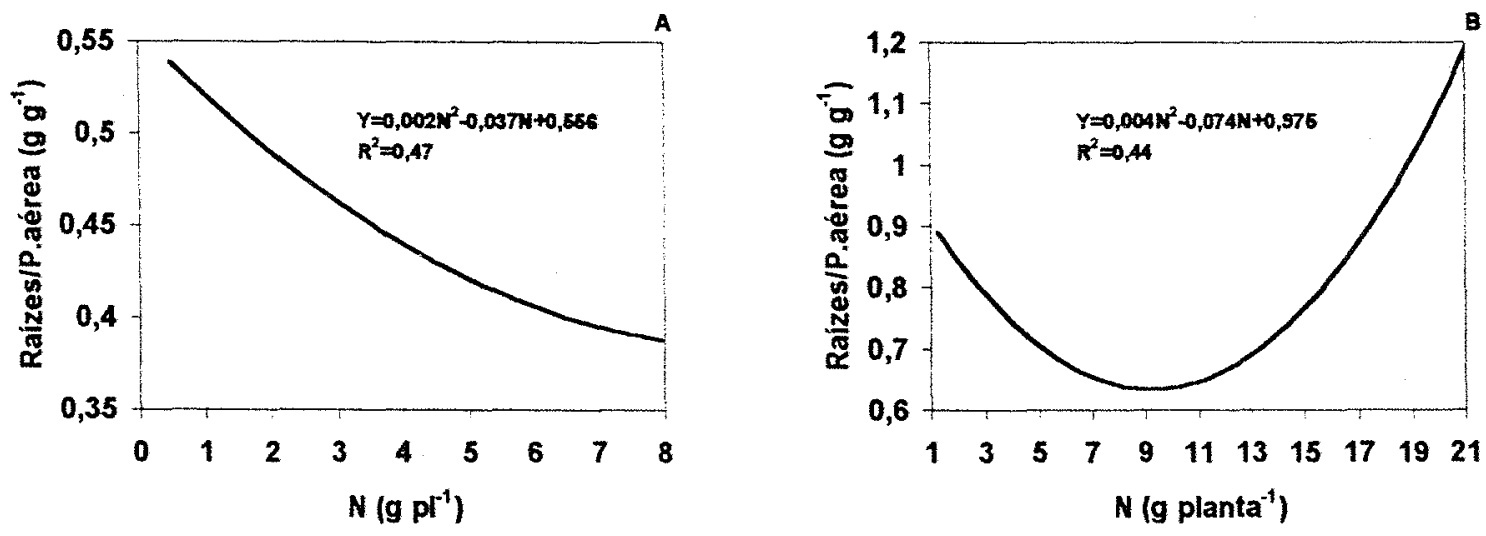

Figura 6: Relação raiz / parte aérea do limoeiro 'Cravo' (A) e da muda de laranjeira 'Valência'l'Cravo' (B).

Alterações na morfologia do sistema radicular, como no seu volume, podem alterar a eficiência de absorção de água e nutrientes no solo, principalmente aqueles mais imóveis no solo, e cujo contato com as raizes ocorre por difusão. As mudas com um sistema radicular mais desenvolvido, quando levadas ao campo, provavelmente terão melhores condições de estabelecimento. A Figura 7 A mostra que o fósforo proporcionou aumentos no volume radicular do porta-enxerto limoeiro 'Cravo'. O volume das raízes variou de 40,28 a 49,05 $\mathrm{cm}^{3}$, sendo que o maior volume foi obtido com a dose de 2,86 g por planta de P. Essa pode ser considerada a dose adequada para a produção de mudas nesse sistema, pois estimulou o estabelecimento do sistema radicular da futura muda. O papel do $P$ no aumento do volume de raizes pode estar no aumento do número e do comprimento das radicelas 
(Marschner, 1995). Nos viveiros da África do Sul são utilizados entre 0,32 e $0,42 \mathrm{~g} \mathrm{dm}^{-3}$ de $\mathrm{P}$ como superfosfato simples (Coetzee et al., 1993). Estes são valores à resposta obtida neste trabalho $\left(0,75 \mathrm{~g} \mathrm{dm}^{-3}\right)$, porém deve ser considerado que estas doses são aplicadas no transplantio e posteriormente as plantas recebem adubação NPK complementar durante o desenvolvimento.

De acordo com Castle (1978), após a enxertia há um favorecimento do crescimento da parte aérea da muda em detrimento do sistema radicular. Esse fato pode ser determinado através da observação da variação do volume radicular, pois após a enxertia houve uma grande redução no sistema radicular com o aumento das doses de N. Pode-se comprovar, quando observa-se, que até a enxertia, o volume de raizes menor foi $40,8 \mathrm{~cm}^{3}$, após este período, houve reduções até para $14,32 \mathrm{~cm}^{3}$, na maior dose de $\mathrm{N}(21,25 \mathrm{~g}$ por planta). $\mathrm{Na}$ menor dose de $\mathrm{N}\left(1,25 \mathrm{~g}\right.$ por planta) o volume foi de $52,86 \mathrm{~cm}^{3}$, indicando que nessa dose, ainda houve um pequeno crescimento de raizes, pois o maior volume na época de enxertia foi de $48,05 \mathrm{~cm}^{3}$ (Figura $7 \mathrm{~B}$ ).
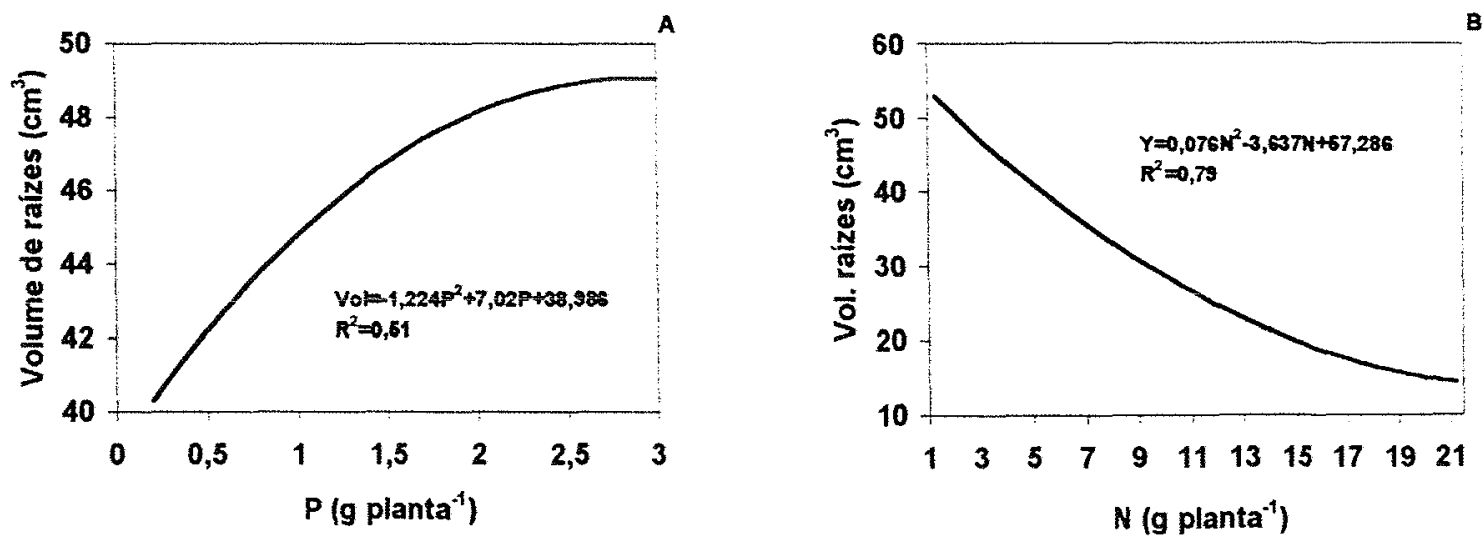

Figura 7: Volume de raizes do limoeiro 'Cravo' (A) e da muda de laranjeira 'Valência'f'Cravo' (B). 
O quociente entre a área foliar e a produção de material seco total das plantas é chamado de razão de área foliar, e fornece uma medida da dimensão relativa do aparelho assimilador das plantas (Magalhães, 1985). A Figura 8 mostra essa relação para as mudas de laranjeira 'Valência'/'Cravo' em função dos tratamentos. Houve interação entre $\mathrm{N}$ e $\mathrm{K}$ sobre este fator, e a maior relação $\left(52,87 \mathrm{~cm}^{2} \mathrm{~g}^{-1}\right)$ foi obtida nas doses de 9,85 e $7,99 \mathrm{~g}$ de $\mathrm{N}$ e K, respectivamente.

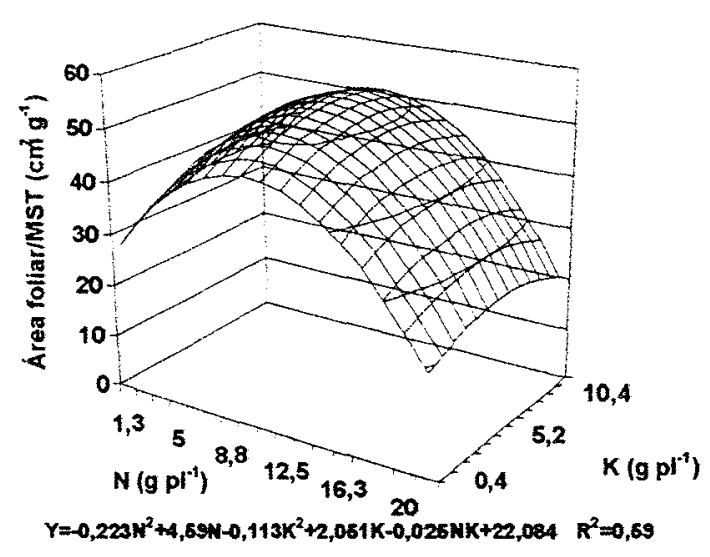

Figura 8: Razão de área foliar (área foliar/ material seco total) da laranjeira 'Valência'l'Cravo'.

As altas correlações obtidas entre as variáveis mostram que as medidas utilizadas foram adequadas para a avaliação do crescimento das plantas. Assim, as correlações obtidas entre diâmetro do caule do limoeiro 'Cravo' e a produção de material seco total $\left(0,683^{* * *}\right)$ e das raízes $\left(0,688^{* * *}\right)$ e o volume radicular $\left(0,649^{* * *}\right)$ indicam que existe uma interdependência positiva entre essas variáveis. 
Para as mudas de laranjeira 'Valência'r'Cravo', as correlações significativas e positivas existentes entre a razão de área foliar e a produção de material seco total $\left(0,631^{* *}\right)$ e altura das plantas $\left(0,706^{* * *}\right)$ indicam que este também é um parâmetro adequado para a avaliação das mudas.

Então as doses de melhor resposta para a produção das mudas, considerando-se a razão de área foliar foram 9,85 e 7,99 g por planta. No entanto, considerando-se a produção total de material seco foram 2,47 e $4,23 \mathrm{~g}$ por planta, respectivamente. Observa-se que considerando-se a área foliar as doses de nutrientes são sempre maiores, mostrando o efeito sobre a expansão das folhas. Os resultados mostram que este aumento de área foliar não refletese em aumentos de material seco.

O volume das raízes do porta-enxerto teve altas correlações com o material seco total e das raízes do porta-enxerto $\left(0,727^{* * *}\right.$ e $\left.0,808^{* * *}\right)$ e também com o material seco total das mudas $\left(0,773^{* * *}\right)$.

\subsection{Conclusões}

Dos resultados obtidos e dentro dos limites estudados, pode-se concluir que para a produção das mudas, as doses de $\mathrm{N}$ e $\mathrm{K}$, calculadas a partir da área foliar foram sempre maiores que aquelas que somente consideram a produção de material seco total. Isso foi observado tanto na produção dos porta-enxertos de limoeiro 'Cravo', como das mudas de laranjeira 'Valência'l'Cravo'. 


\section{FOTOSSÍNTESE DE MUDAS DE CITROS CULTIVADAS EM VASOS EM FUNÇÃO DA ADUBAÇÃO COM NITROGÊNIO, FÓSOFORO E POTÁSSIO}

\section{Resumo}

Cultivou-se em ambiente protegido mudas de laranjeira 'Valência' (Citrus sinnensis L. Osbeck) sobre porta-enxerto de limoeiro 'Cravo' (C. limonia Osbeck) em vasos com capacidade para $3,8 \mathrm{~L}$ com substrato a base de casca de Pinus. Avaliou-se os efeitos do fornecimento dos nutrientes $\mathrm{N}, \mathrm{P}$ e K, sobre o crescimento do porta-enxerto e das mudas. Utilizou-se um esquema fatorial fracionário (1/5) $5^{3}$ com um delineamento em 5 blocos casualisados. Os tratamentos (g por planta ${ }^{-1}$ ) consistiram em 5 doses de $\mathrm{N}: 1,25 ; 6,25 ; 11,25$; 16,$25 ; 21,25 ; 5$ doses de $\mathrm{K}: 0,42 ; 3,75 ; 6,22 ; 9,34 ; 12,45$ e 5 doses de $\mathrm{P}: 0,19$; 0,$89 ; 1,59 ; 2,29 ; 2,99$. $\mathrm{N}$ e $\mathrm{K}$ foram fornecidos semanalmente, sendo $37,5 \%$ da dose aplicada na produção do porta-enxerto e $62,5 \%$ após a enxertia. O P foi fornecido todo no plantio do porta-enxerto. Avaliou-se a taxa de assimilação líquida $(A)$, transpiração $(E)$, condutância estomática $(g)$, concentração interna de $\mathrm{CO}_{2}$ (Ci) e eficiência de uso de água (EUA). Funções de resposta foram ajustadas e os niveis de nutrientes foram calculados para se obter produções máximas. Os resultados mostraram que as doses excessivas de $\mathrm{N}$ utilizadas limitaram a fotossintese. As doses intermediárias da adubação potássica interferiram positivamente nos parâmetros. O $P$ teve pouca influência nos parâmetros avaliados. No porta-enxerto limoeiro 'Cravo', a assimilação de 
$\mathrm{CO}_{2}$, transpiração, e eficiência do uso da água do foram relacionados com os teores foliares de K. Nas mudas de laranjeira 'Valência', a assimilação de $\mathrm{CO}_{2}$, e a eficiência do uso da água do foram relacionados positivamente com os teores foliares de $\mathrm{Ke}$ a concentração interna de $\mathrm{CO}_{2}$ negativamente.

\section{CONTAINERIZED CITRUS NURSERY TREES PHOTOSYNTHESIS} DUE TO NITROGEN, PHOSPHORUS AND POTASSIUM FERTILIZATION.

\section{Summary}

'Valencia' sweet orange nursery trees (Citrus sinensis L. Osbeck) budded on Rangpur lime rootstocks (C. limonia Osbeck) were grown in a protected environment in $3,8 \mathrm{~L}$ containers with Pinus bark, vermiculite and perlite substract. NPK fertilization effect were evaluated. The experiment was carried out as a (1/5) $5^{3}$ factorial in a complete randomized block design. Treatments comprised (g per plant) five levels of $\mathrm{N}: 1.25 ; 6.25 ; 11.25 ; 16.25 ; 21.25$; five levels of $\mathrm{K}$ : $0.42 ; 3.75 ; 6.22 ; 9.34 ; 12.45$; and five levels of $P: 0.19 ; 0.89 ; 1.59 ; 2.29 ; 2.99$. Nitrogen and $K$ were applieded weekly, and $37.5 \%$ of the total fertilization was applied to rootstocks. All $P$ was supplied at planting. Carbon dioxide assimilation rate $(A)$, transpiration rate $(E)$, stomatal conductance $(g)$, internal $\mathrm{CO}_{2}(\mathrm{Ci})$ were evaluated and water use efficiency (WUE) was estimated by the relation $A E^{-1}$. Response functions were adjusted and nutrient rates for maximum yield are presented. High levels of $\mathrm{N}$ decreased net photosynthesis. Potassium at intermediate fertilization levels had positive effects on the evaluated parameters. Phosphorus had little interference on net photosynthesis. Rangpur lime rootstock $A, E$ and WUE were positively related to $K$ foliar concentration. 'Valencia' nursery trees $A$ and WUE were positively related and Ci was inversely related to $\mathrm{K}$ foliar concentration. 


\subsection{Introdução}

A fotossíntese pode ser dividida em uma série de processos interligados: interceptação da radiação incidente e sua conversão em energia química como NADPH e ATP, difusão do $\mathrm{CO}_{2}$ aos cloroplastos e redução a triose fosfato, a partir desse composto pode ocorrer a síntese do amido nos cloroplastos ou da sacarose no citoplasma e finalmente o transporte dos fotoassimilados pelo floema para outros órgãos da planta (Moorby \& Besford, 1983). As principais limitações ao processo fotossíntético são a luz $e \circ \mathrm{CO}_{2}$. Porém, os nutrientes minerais estão ligados a todos as etapas desse processo, e muitos deles atuam em mais de um estágio (Natr, 1972; Barker, 1979; Longstreth \& Nobel, 1980; Moorby \& Besford, 1983).

O nitrogênio das folhas está relacionado com o teor de clorofila, com a transpiração e com a assimilação líquida de $\mathrm{CO}_{2}$ (Longstreth \& Nobel, 1980), além da eficiência na carboxilação (Syvertsen, 1984). Estas relações positivas entre o nitrogênio na folha e a capacidade fotossintética ocorrem em função da alta porcentagem do nitrogênio total da folha que está na forma da enzima envolvida no processo da carboxilação, a Rubisco (Ribulose - 1,5 - bifosfato). De acordo com Marschner (1995), entre 20 e 30\% do nitrogênio total das folhas das plantas de ciclo C3 estão na forma da Rubisco.

Syvertsen (1987) relacionou os teores foliares de nitrogênio com a capacidade fotossintética de plântulas de laranjeira e de pomelo. O nitrogênio nas folhas correlacionou-se positivamente com a assimilação líquida de $\mathrm{CO}_{2}$, com a eficiência do uso da água, com o teor de clorofila e com a eficiência na carboxilação e, negativamente com o ponto de compensação de $\mathrm{CO}_{2}$.

Os resultados da literatura não relacionam claramente os efeitos do $P$ sobre a fotossíntese líquida (Barker, 1979 e Natr, 1972). Syvertsen (1987) não encontrou relação entre os teores foliares de fósforo com a capacidade fotossintética de plântulas de laranjeira e de pomelo. 
O P atua na fixação do $\mathrm{C}$ nos cloroplastos, pois o produto final do Ciclo de Calvin é a conversão de 3 moléculas de $\mathrm{CO}_{2}$ em uma de triose-fosfato. Os cloroplastos necessitam de um fornecimento de $P$ inorgânico para a manutenção das taxas de fixação de $C$, pois existe uma relação estequiométrica entre o consumo de $\mathrm{P}$ e produção da triose fosfato. No citosol, a triose é então convertida em sacarose (Sivak \& Walker, 1986). Deficiências severas de $P$ interferem no transporte de fotoassimilados das folhas, levando a um acúmulo de amido (Barker, 1979).

Vários autores mostram uma redução na fotossíntese líquida e aumento na respiração na deficiência de $K$. Este nutriente regula a abertura dos estômatos e interfere nas taxas de transferência do $\mathrm{CO}_{2}$ nas folhas. $\mathrm{Na}$ sua deficiência ocorre diminuição da fosforilação. $O$ transporte de fotossintetados é também inibido pela deficiência de $K$, ocorrendo uma interrupção na conversão dos produtos intermediários em sacarose e um conseqüente acúmulo de carboidratos solúveis, inclusive açúcares redutores. O acúmulo desse nutriente reduz o potencial osmótico, levando à uma redução na taxa de transpiração. $O$ potássio é ativador de numerosas enzimas e, portanto é requerido em numerosos processos metabólicos.(Barker, 1979, Natr, 1972; Huber, 1985).

Kriedman (1968 e 1971) descreveu algumas características importantes sobre a atividade fotossintética das folhas de citros que nos últimos 30 anos ainda não estão bem esclarecidas. Estas características incluem as taxas relativamente baixas de assimilação de $\mathrm{CO}_{2}$, de condutância estomática e de condutância do mesófilo, oscilações cíclicas de A e E com periodicidade entre 20 e 40 min. Syvertsen \& Lloyd (1994) apresentaram vários mecanismos de resposta das plantas cítricas ao ambiente, baseados nos fluxos de água e de $\mathrm{C}$.

O objetivo deste trabalho foi avaliar o efeito da adubação NPK sobre a fotossíntese do porta-enxerto limoeiro 'Cravo' e das mudas de laranjeira 'Valência'l'Cravo'. 


\subsection{Material e Métodos}

O experimento foi conduzido em viveiro demonstrativo do sistema de produção de mudas certificadas de citros, no Centro de Citricultura "Sylvio Moreira", do Instituto Agronômico - IAC, em Cordeirópolis-SP. Os detalhes do viveiro são apresentados por Carvalho \& Laranjeira (1994). As características químicas do substrato, o delineamento experimental, tratamentos, instalação e condução do experimento são os mesmos descritos nos itens 3.2.1 a 3.2.3.

\subsubsection{Avaliações}

As avaliações da atividade fotossintética foram realizadas na folha mais jovem totalmente expandida a partir do ápice para a base da planta, tanto no caso do limoeiro 'Cravo', como no caso das mudas de 'Valência'l'Cravo'. Estas folhas foram então amostradas para determinação dos teores totais de $\mathrm{N}, \mathrm{P}$ e K.

\subsubsection{Atividade fotossintética}

Foram realizadas avaliações nos porta-enxertos e nas mudas, das taxas de assimilação líquida $\left(A, \mu \mathrm{mol} \mathrm{CO}_{2} \mathrm{~m}^{-2} \mathrm{~s}^{-1}\right)$ e de transpiração $\left(E, m m o l ~ \mathrm{H}_{2} \mathrm{O} \mathrm{m}^{-2}\right.$ $\left.\mathrm{s}^{-1}\right)$, da condutância estomática $\left(\mathrm{g}, \mathrm{mmol} \mathrm{H}_{2} \mathrm{O} \mathrm{m}^{-2} \mathrm{~s}^{-1}\right)$ e da concentração interna de $\mathrm{CO}_{2}\left(\mu \mathrm{mol} \mathrm{CO}_{2} \mathrm{~mol}^{-1}\right.$ ar). A eficiência de uso de água (EUA) foi obtida através da relação $A E^{-1}$. Utilizou-se um sistema de fotossíntese portátil por radiação infravermelha (PPS LI-6200 Licor, Inc. Lincon, Nebraska, USA). As medições foram realizadas nas folhas mais jovens totalmente expandidas, em uma câmara com condições controladas de radiação $\left(700 \mu \mathrm{mol}\right.$ fótons $\left.\mathrm{m}^{-2} \mathrm{~s}^{-1}\right)$, temperatura $\left(25^{\circ} \mathrm{C}\right)$ e concentração externa de $\mathrm{CO}_{2}\left(350 \mu \mathrm{mol} \mathrm{CO}_{2} \mathrm{~mol}^{-1} \mathrm{ar}\right)$. Essas medidas foram realizadas na Seção de Fisiologia Vegetal do Instituto Agronômico de Campinas - IAC. Detalhes de construção e funcionamento do sistema de iluminação encontram-se em Machado \& Pereira (1990). 


\subsubsection{Determinação dos teores totais de nutrientes nos tecidos}

A obtenção dos extratos e determinações dos teores totais seguiram a metodologia descrita por Sarruge \& Haag (1974). Após digestão sulfúrica do material o $\mathrm{N}$ foi determinado pelo método semi-micro Kjedahl. No extrato obtido da digestão nítrico-perclórica determinou-se $P$ por colorimetria de vanadato molibdato, o K por fotometria de chama. A partir das análises, foram obtidos os teores totais de $\mathrm{N}, \mathrm{P}$ e K $\left(\mathrm{g} \mathrm{kg}^{-1}\right)$.

\subsubsection{Análise estatística}

A análise de variância realizada seguiu os mesmos procedimentos descritos no item 3.2.4. Na Tabela 3 estão os coeficientes da regressão em função das doses de $N, P$ e $K$. As análises estatísticas foram realizadas utilizando o programa estatístico SAS (SAS Institute, 1996). Quando as respostas foram significativas apenas para 1 ou 2 nutrientes, as funções foram simplificadas, considerando-se os niveis menores dos demais nutrientes. Determinou-se as doses dos nutrientes que proporcionaram as valores dos parâmetros analisados através do cálculo $d x / d y=0$. Estudou-se as correlações (r) entre os parâmetros fotossintéticos e os teores de nutrientes nas folhas. 


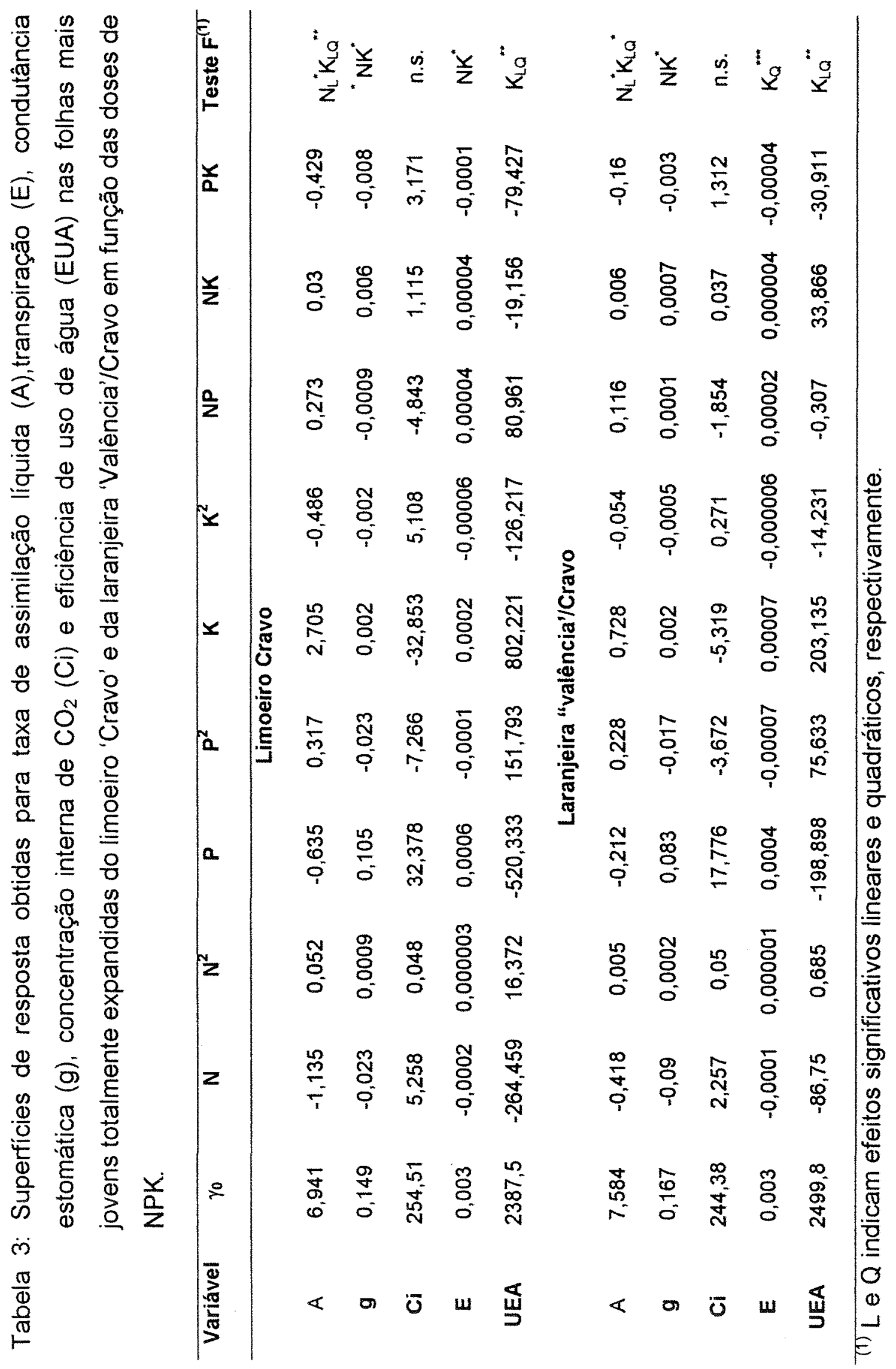




\subsection{Resultados e Discussão}

Houve interação da adubação com $\mathrm{N}$ e K sobre assimilação de $\mathrm{CO}_{2}(\mathrm{~A})$, tanto no porta-enxerto limoeiro 'Cravo' como nas mudas de laranjeira 'Valência' (Figura 9). As doses de $\mathrm{N}$ atuaram reduzindo $\mathrm{A}$. As maiores assimilações foram obtidas nas doses intermediárias de $\mathrm{K}$ e nas menores doses de $\mathrm{N}(0,47$ e 1,25 g por planta). O papel positivo do fornecimento de $\mathrm{N}$ e $\mathrm{K}$ sobre este parâmetro foi relatado por Longstreth \& Nobel (1980).

As taxas máximas de assimilação de $\mathrm{CO}_{2}$, ao redor de $10 \mu \mathrm{mol} \mathrm{m} \mathrm{m}^{-2} \mathrm{~s}^{-1}$ foram semelhantes às encontradas por outros autores, quando medidas sob condições favoráveis (Syvertsen, 1984 e Medina \& Machado, 1998).

Existem outros efeitos do $\mathrm{N}$ na fotossíntese além de sua participação nos complexos de proteínas e de clorofila nos cloroplastos. A diminuição da assimilação do $\mathrm{CO}_{2}$ observada com o aumento das doses de $\mathrm{N}$, pode estar relacionada com a fonte de adubo nitrogenado utilizado, o $\mathrm{NH}_{4} \mathrm{NO}_{3}$. $A$ acumulação de altos níveis de amônio nas células podem acusar danos severos tais como proteólises, alterações estruturais e funcionais das membranas, inibição da síntese de clorofila, destruição de clorofila, redução da fosforilação oxidativa, degradação na estrutura dos cloroplastos e diminuição dos carboidratos (Barker, 1979, Gil \& Gonzalo, 1993). A acumulação de $\mathrm{NH}_{4}$ nas plantas inibem o transporte de glicose produzida na fotossíntese (Bassham et al., 1984). Por outro lado a absorção e assimilação de $\mathrm{NO}_{3}$ requerem energia e a utilização de agentes redutores que seriam utilizados mo processo e fixação do $\mathrm{CO}_{2}$ (Barker, 1979). Syvertsen \& Lloyd (1994) confirmaram que o transporte eletrônico também pode reduzir $A$. 


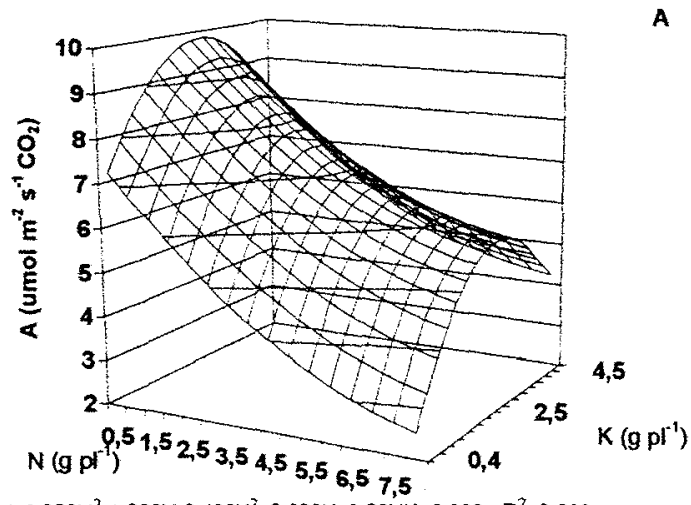

$Y=0,052 N^{2}-1,083 N-0,486 K^{2}+2,623 K+0,03 N K+6,832 \quad R^{2}=0,263$

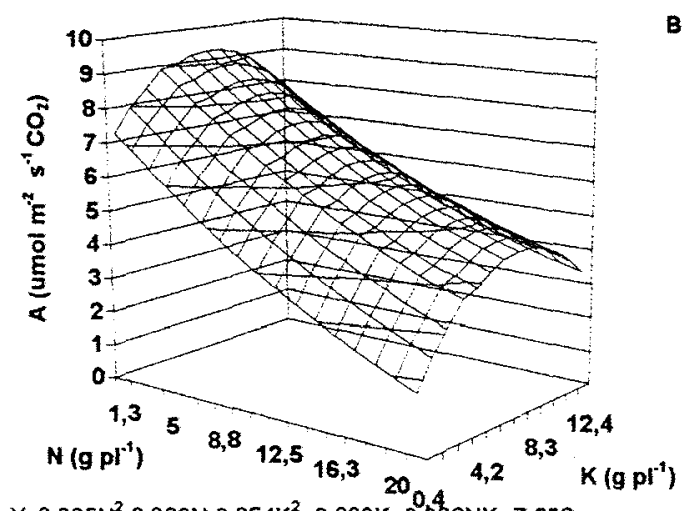

$Y=0,005 N^{2}-0,396 N-0,054 K^{2}+0,698 K+0,066 N K+7,552$

Figura 9: Assimilação de $\mathrm{CO}_{2}(\mathrm{~A})$ do porta-enxerto limoeiro 'Cravo' (A) e da laranjeira 'Valência'/'Cravo' (B).

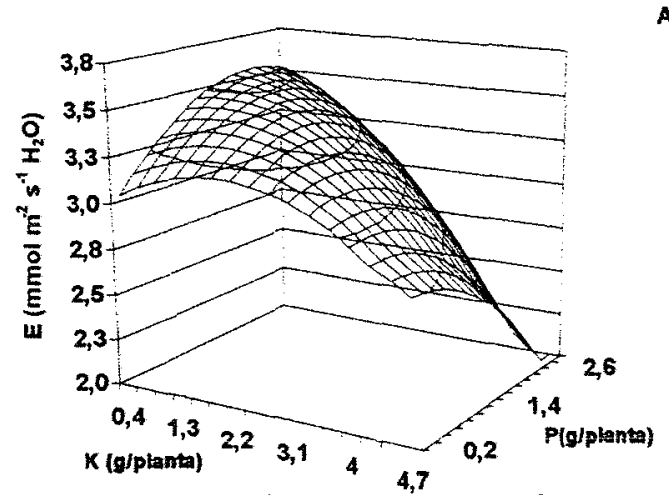

$Y=0,102 P^{2}+0,572 P-0,061 K^{2}+0,266 K-0,114 P K+2,616 \quad R^{2}=0,193$
A

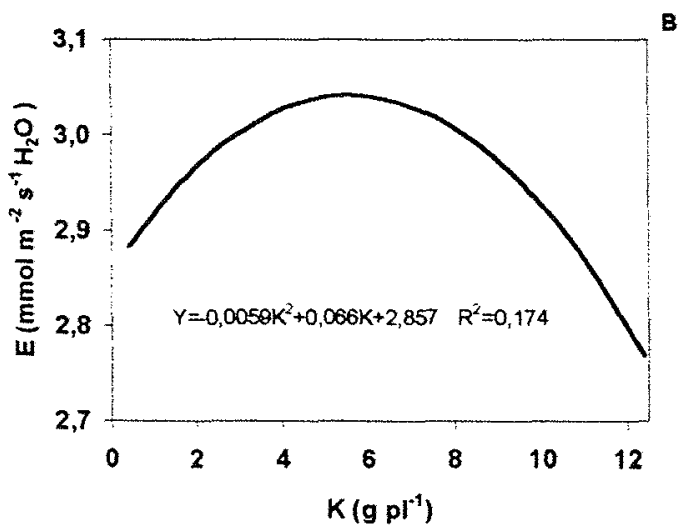

Figura 10: Taxa de transpiração (E) do porta-enxerto limoeiro 'Cravo' (A) e da laranjeira 'Valência'/'Cravo' (B).

A taxa de transpiração (E, Figura 10A) do limoeiro 'Cravo' teve influência da adubação potássica e fosfatada, o maior valor $\left(3,51 \mathrm{mmol} \mathrm{m}^{-2} \mathrm{~s}^{-1} \mathrm{H}_{2} \mathrm{O}\right)$, foi obtido na menor dose de $\mathrm{K}$ e maior de $\mathrm{P}(0,47$ e $2,99 \mathrm{~g}$ por planta, 
respectivamente). Nas mudas (Figura 10B), o fornecimento de $\mathrm{K}$ aumentou $\mathrm{E}$ até o valor de $3,04 \mathrm{mmol} \mathrm{m}^{-2} \mathrm{~s}^{-1} \mathrm{H}_{2} \mathrm{O}$, obtido na dose de $5,59 \mathrm{~g}$ por planta, quando então passou a diminuir os valores. De acordo com Huber (1984) existem vários relatos na literatura mostrando a menor transpiração de plantas deficientes em K. Segundo Sinclair \& Allen Jr. (1982), em condições normais de cultivo dos citros, a transpiração estabiliza-se em torno de 3,5 e $5 \mathrm{mmol} \mathrm{m}^{-2} \mathrm{~s}^{-1}$.

A redução na fotossíntese causada pela deficiência moderada de $K$ está relacionada inicialmente com aumentos na resistência do mesófilo. Aumentos na resistência estomatal estão relacionados com deficiências severas do nutriente, como foi demonstrado por Natr (1972) e Logstrech \& Nobel (1980). Provavelmente por este motivo não foi encontra relação entre a adubação potássica e a condutância estomática.
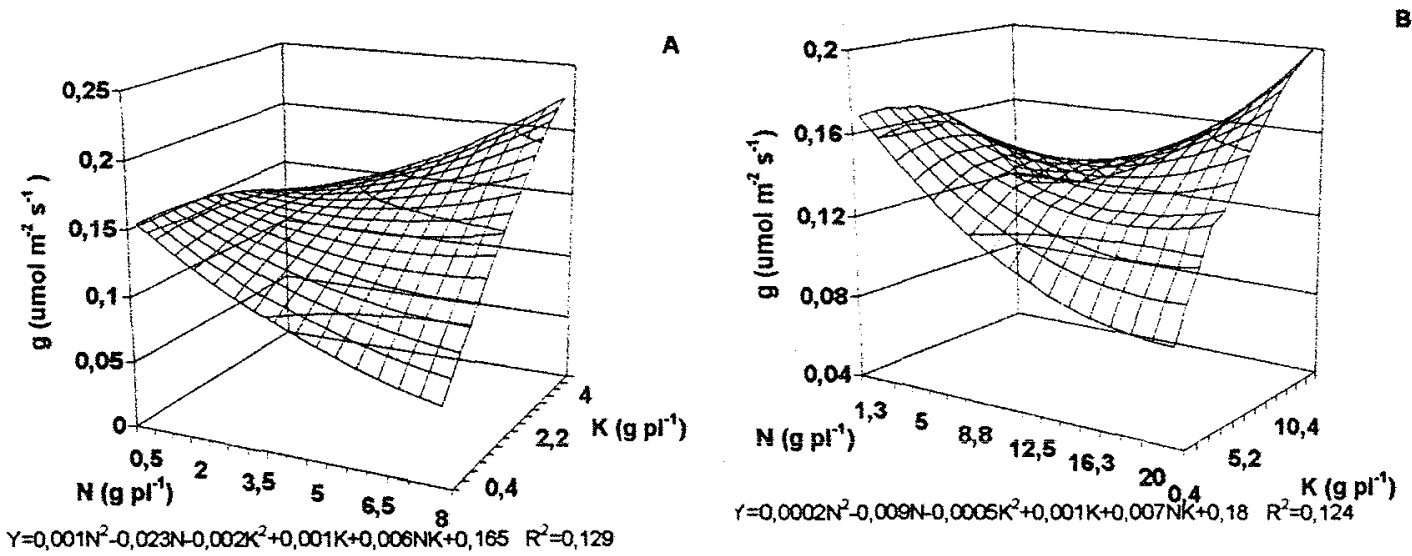

Figura 11: Condutância estomâtica (g) do porta-enxerto limoeiro 'Cravo' (A) e da laranjeira 'Valência'l'Cravo' (B).

Os resultados para o porta enxerto e para as mudas mostraram o efeito do $\mathrm{N}$ e do $\mathrm{K}$ sobre a condutância estomática. A Figura 11 mostra que o aumento no fornecimento de $\mathrm{K}$ da menor dose para as maiores doses 
aumentaram a condutância, enquanto que as doses de $\mathrm{N}$ tiveram o efeito oposto, diminuindo este parâmetro.

O P interferiu muito pouco na fotossíntese uma vez que afetou apenas a transpiração do porta-enxerto. O papel deste nutriente na fotossíntese é variável e é geralmente menor que dos outros macronutrientes (Barker, 1979; Natr, 1972) e tem sido atribuído a um aumento da resistência do mesófilo à transferência de $\mathrm{CO}_{2}$ (Natr, 1972).

A epiderme das folhas reduzem as perdas de vapor d'água e de $\mathrm{CO}_{2}$ e também são um meio de controle da assimilação e do transporte pelos estômatos. O estômato exerce o papel de controlar o balanço entre as perdas de água e ganhos de carbono, ou seja a produção de biomassa. Por isso as medidas da condutância dos estômatos são importantes neste estudo, buscando-se neste sistema de cultivo maximizar a eficiência do uso da água. Pois as plantas são cultivadas em vasos e têm um volume de substrato restrito para a exploração das raizes.

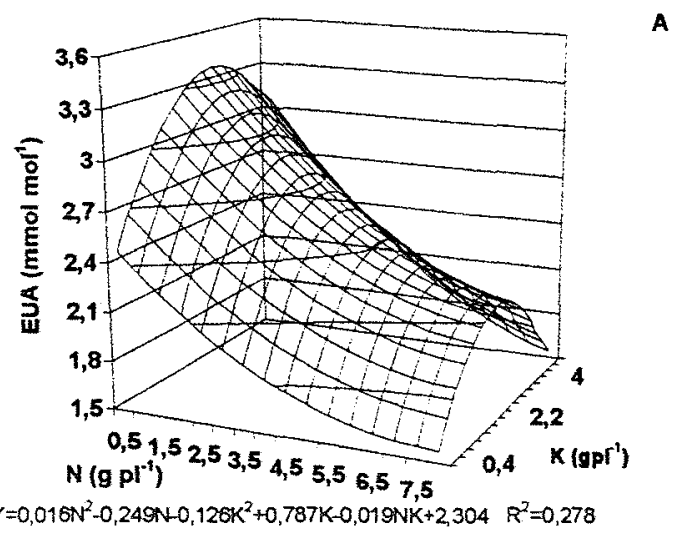

A

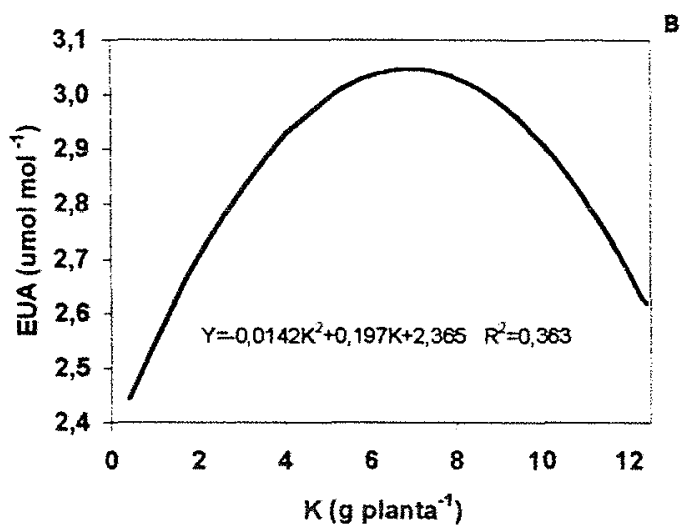

Figura 12:Eficiência do uso da água (EUA) do porta-enxerto limoeiro 'Cravo' (A) e da laranjeira 'Valência'l'Cravo' (B). 
Na Figura 12 são apresentados os resultados da eficiência do uso da água (EUA). Para o porta-enxerto houve interação entre o fornecimento de $\mathrm{Ne}$ $\mathrm{K}$. Na muda o K aumento a EUA até a dose de $6,9 \mathrm{~g}$ por planta de $\mathrm{K}$, quando obteve-se $3046 \mu \mathrm{mol} \mathrm{mol}^{-1}$. Esses resultados eram esperados devido às funções que estes nutrientes exercem na fotossíntese (Barker, 1979; Huber, 1984, Marschner, 1995). Os valores de EUA estão abaixo daqueles obtidos por Syvertsen (1985), cujos valores máximos foram em torno de $8 \mu \mathrm{mol} \mathrm{mol}^{-1}$.

Realizou-se um estudo de correlação entre as variáveis relacionadas à fotossíntese, os altos coeficientes encontrados indicam a existência de uma interdependência entre estes fatores (Figura 13).

A condutância da folha pode influenciar diretamente a fotossintese interferindo na concentração de $\mathrm{CO}_{2}$ disponivel para a carboxilação. Variações na resistência da folha, induzidas pela variação da umidade ou pela abertura estomatal relacionaram-se com a fotossíntese e com a transpiração de folhas de laranjeira 'Washington Navel' e 'Valência' (Kriedemann, 1971). A Figura 13 mostra que houve uma relação quadrática entre $A$ e g, sendo que os maiores valores $\left(A=10,0\right.$ e $\left.10,7 \mu \mathrm{mol} \mathrm{m} \mathrm{m}^{-2} \mathrm{~s}_{2}\right)$ foram obtidos com g em $0,3 \mathrm{mmol} \mathrm{m}^{-2}$ $\mathrm{s}^{-1} \mathrm{H}_{2} \mathrm{O}$. Khairi \& Hall (1976) também demonstraram uma estreita relação entre condutância e fotossintese em laranjeiras.

A Figura 13B mostra que entre a assimilação de $\mathrm{CO}_{2}$ e a taxa de transpiração houve uma relação positiva e direta. Gama-Rodrigues et al. (1995) encontraram as mesmas tendências em mudas de cacaueiro. No sistema de produção de mudas cítricas em vasos em função do volume de exploração das raizes ser restrito, seria desejável que as altas taxas de fotossíntese líquida fossem acompanhadas por uma regulação adequada das perdas de água, pois as altas taxas de transpiração podem causar déficit hídrico. Porém a regulação das perdas de água são obtidas pelo fechamento dos estômatos, que também reduz a fotossintese (Kriedmann, 1971; Khairi \& Hall, 1976). Uma alternativa 
seria incrementar os aspectos não estomáticos da fotossintese, através do aumento da produção de proteinas (Khairi \& Hall, 1976).
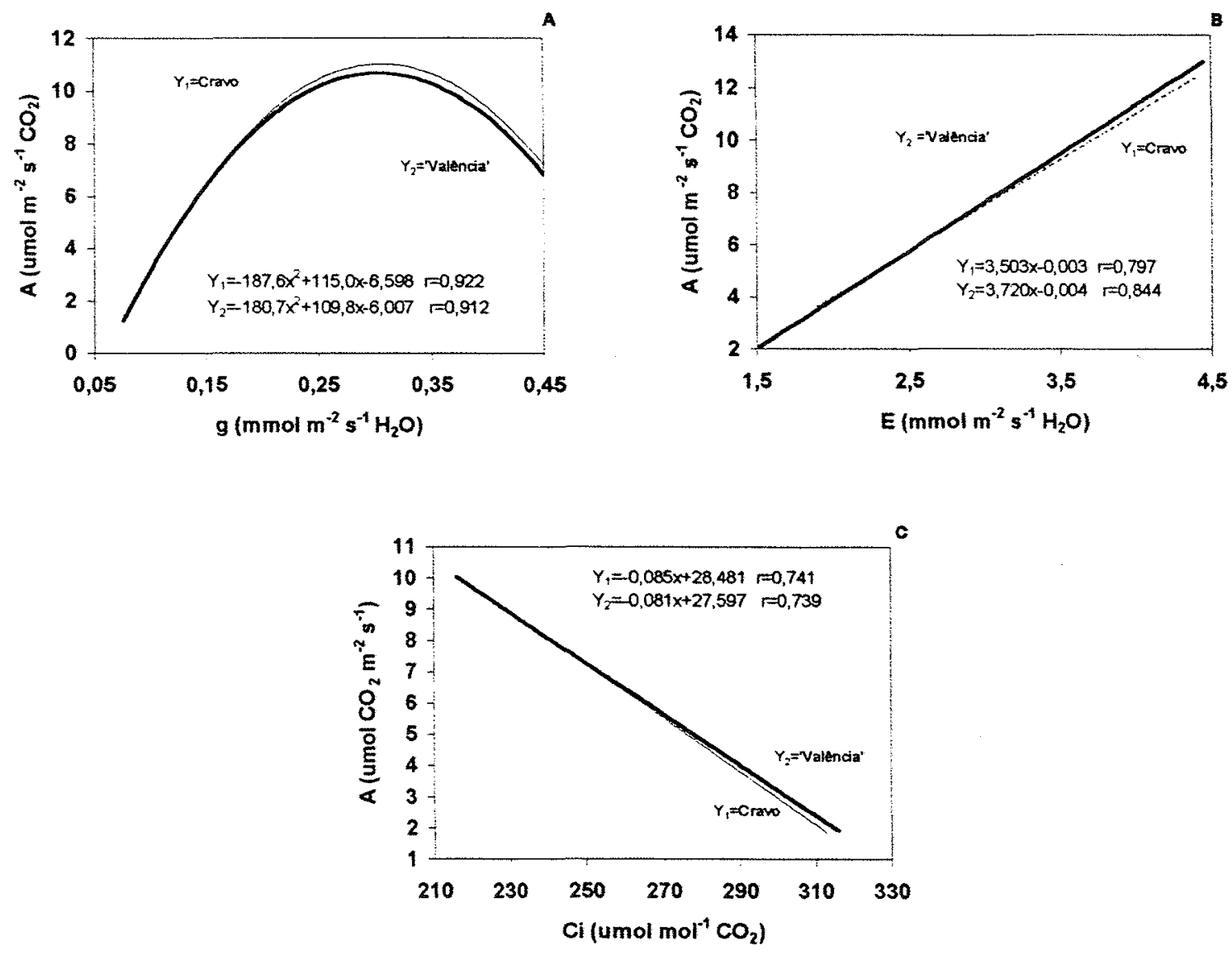

Figura 13: Relação entre as variáveis assimilação de $\mathrm{CO}_{2}(\mathrm{~A})$, condutância estomática $(g)$, taxa de transpiração $(E)$ e concentração interna de $\mathrm{CO}_{2}(\mathrm{Ci})$. 
A concentração interna de $\mathrm{CO}_{2}$ indica quais fatores estão limitando a assimilação de $\mathrm{CO}_{2}$. Quando $\mathrm{Ci}$ decresce as limitações são relativas ao funcionamento dos estômatos, já quando a $\mathrm{Ci}$ aumenta as limitações estāo ocorrendo no mesófilo foliar (Long \& Halgren, 1987). Os resultados apresentados na Figura 13C, mostram a relação inversa entre A e Ci. Esta relação negativa sugere que não há limitações ao funcionamento dos estômatos e provavelmente ocorreu uma diminuição da atividade da Rubisco, reduzindo sua regeneração. Um dos fatores que também pode limitar a assimilação de $\mathrm{CO}_{2}$ é a atividade da Rubisco (Syvertsen \& Lloyd, 1994). E a assimilação de $\mathrm{CO}_{2}$ provavelmente foi limitada por este fator, levando a um menor suprimento de RuBp para a carboxilação, de acordo com que demonstraram Farquhar et al. (1980). Isto pode comprovar o motivo da diminuição na assimilação de $\mathrm{CO}_{2}$ com o aumento das doses de $\mathrm{N}$.

Estabeleceu-se as correlações entre os teores dos nutrientes N, P e K nas folhas do porta-enxerto e das mudas com os parâmetros da fotossíntese. Considerando-se todos os teores de $\mathrm{N}$ e $\mathrm{K}$ nas folhas do limoeiro 'Cravo' em função dos tratamentos não estabeleceu-se relações com os parâmetros avaliados. Isso devido aos altos niveis de adubação utilizados no experimento, que pode ter levado à absorção excessiva destes nutrientes. Então quando limitou-se estes níveis à $30 \mathrm{~g} \mathrm{~kg}^{-1}$ de $\mathrm{N}$ e $15 \mathrm{~g} \mathrm{~kg}^{-1}$ de $\mathrm{K}$, são obtidas relações positivas. A Figura 14A e 14B mostram que os teores de $\mathrm{N}$ e $\mathrm{K}$ relacionaram-se positivamente com a assimilação de $\mathrm{CO}_{2}(\mathrm{~A})$, até os limites propostos. Apesar de ambos nutrientes atuarem sobre o mesmo parâmetro, isso ocorre através de mecanismos diferentes em função das funções destes nutrientes no metabolismo vegetal (Barker, 1979; Huber, 1984). Syvertsen (1987) também observou que os teores de $\mathrm{N}$ na folha foram positivamente associados com $\mathrm{A}$. 

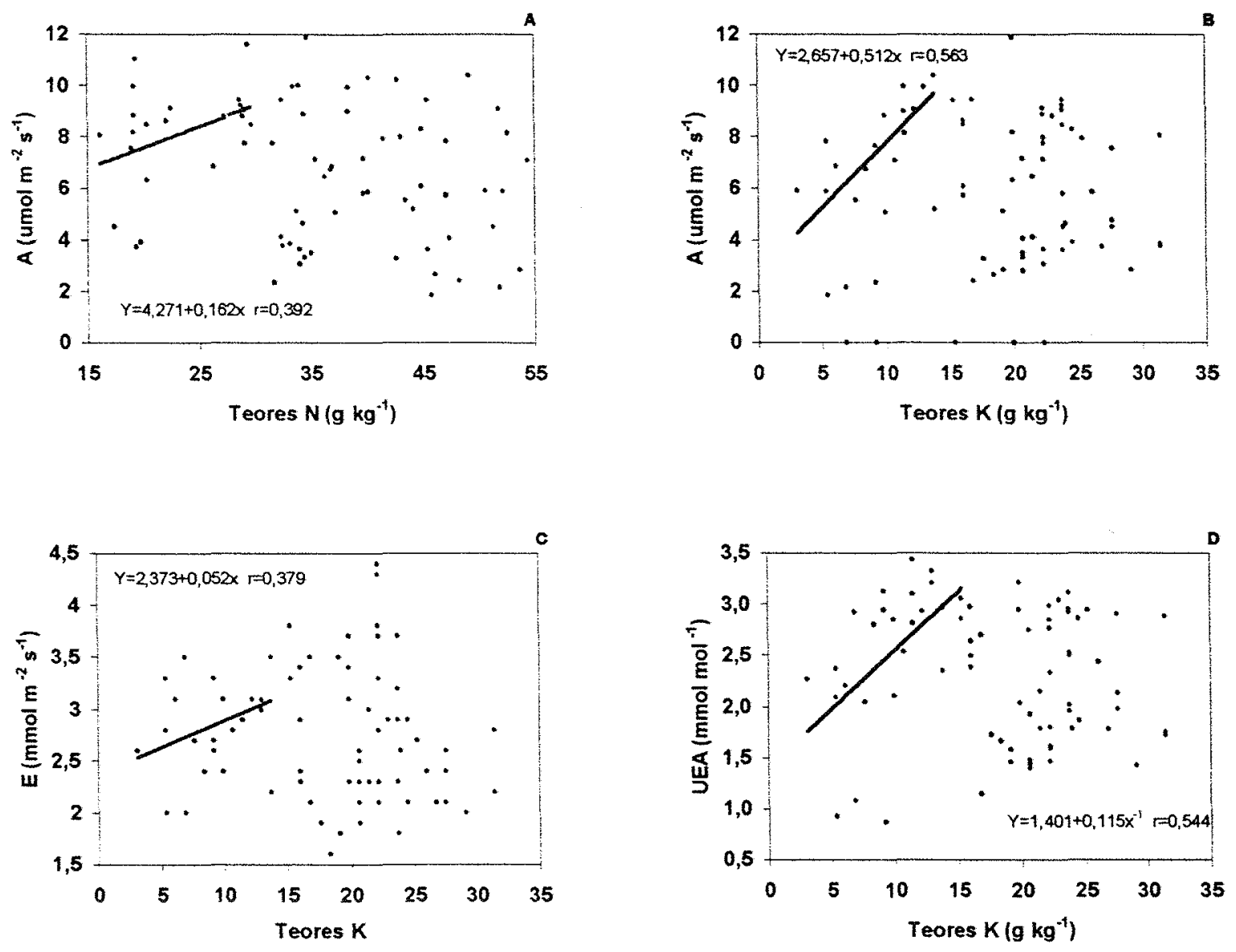

Figura 14: Relação entre as variáveis assimilação de $\mathrm{CO}_{2}(\mathrm{~A})$, eficiência do uso da água (EUA) e taxa de transpiração $(E)$ e os teores de $\mathrm{N}$ e $\mathrm{K}$ no porta-enxerto limoeiro 'Cravo'. 
A transpiração relacionou-se com os teores de $\mathrm{K}$, e aumentou com os teores até $15 \mathrm{~g} \mathrm{~kg}^{-1}$ (Figura 14C). E este aumento da transpiração não foi prejudicial, pois como já demonstrou-se na Figura 13B existe uma relação direta entre $E$ e A. A Figura 14D mostra que este aumento, não ocasionou prejuízos para os porta-enxertos, uma vez que o UEA relacionou-se diretamente e de forma linear com os teores de $\mathrm{K}$ até o limite proposto. Mostrando que com maiores teores de Ko porta-enxerto foi mais eficiente.

O mesmo procedimento foi adotado para as mudas de laranjeira 'Valência'f'Cravo', limitando-se os teores do nutriente $\mathrm{K}$ nas folhas em $20 \mathrm{~g} \mathrm{~kg}^{-1}$. A partir daí foram estabelecidas relações positivas com a assimilação de $\mathrm{CO}_{2} \mathrm{e}$ EUA (Figura $15 \mathrm{~A}$ e $15 \mathrm{C}$ ). Não houve correlação com a transpiração (15 B). E a Figura $15 \mathrm{D}$ mostra a relação inversa entre os teores foliares de $\mathrm{K}$ e a concentração interna de $\mathrm{CO}_{2}$, mostrando a importância do nutriente em regular a eficiência do processo fotossintético das mudas.

O K está ligado à enzimas chave do processo fotossintético como a Rubisco (Ribulose difosfato carboxilase), que tem sua síntese inibida na ausência do nutriente (Huber, 1984). A deficiência do $\mathrm{K}$ pode levar também à um aumento na resistência do mesófilo à difusão do de $\mathrm{CO}_{2}$ (Moorby \& Besford, 1983). 

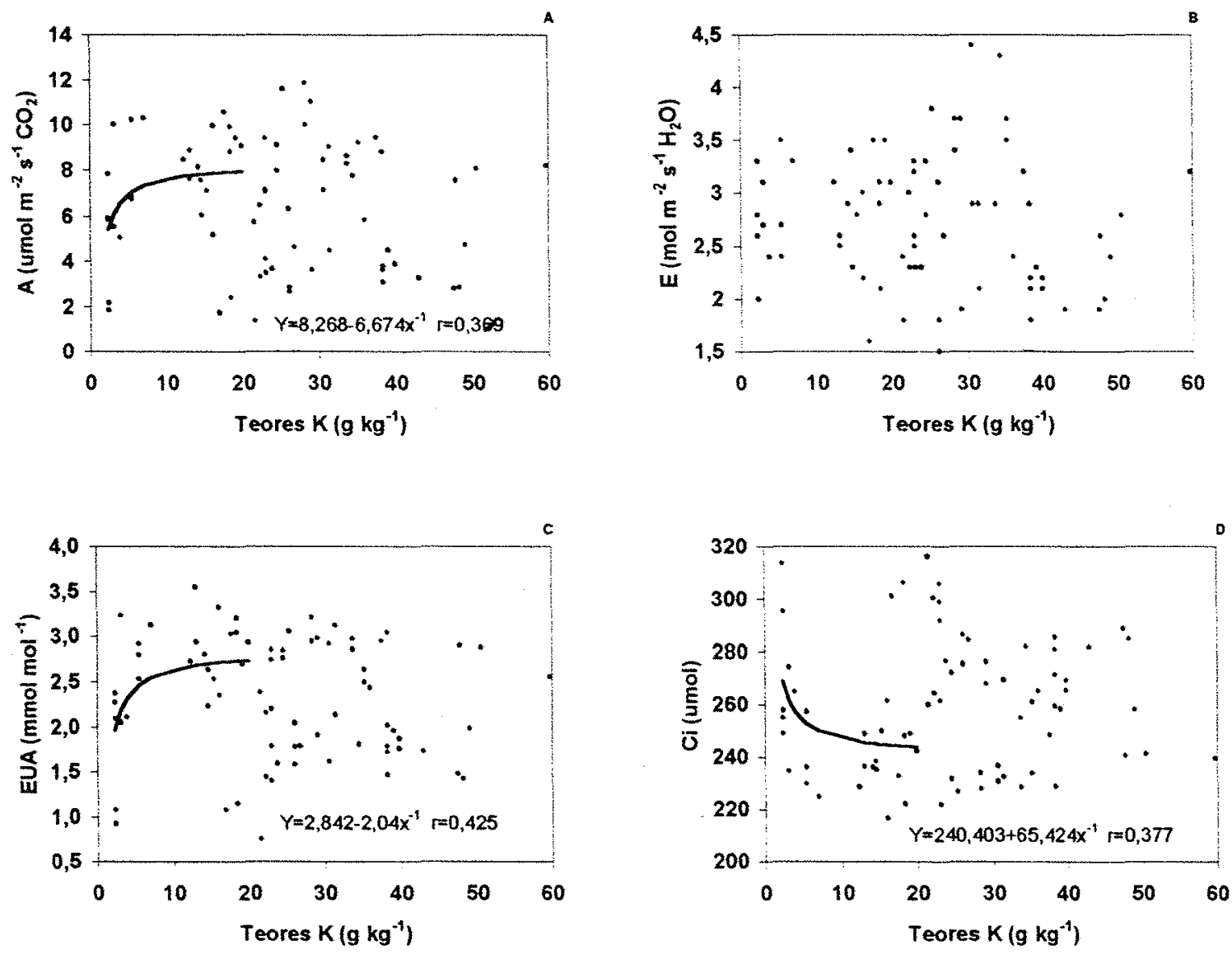

Figura 15: Relação entre as variáveis assimilação de $\mathrm{CO}_{2}(\mathrm{~A})$, eficiência do uso da água (EUA), taxa de transpiração $(E)$ e a concentração intema de $\mathrm{CO}_{2}$ e os teores $\mathrm{K}$ nas mudas de laranjeira 'Valência'/'Cravo'. 
Folhas de plantas deficientes em $\mathrm{K}$, geralmente têm taxas de fixação de $\mathrm{CO}_{2}$ e translocação de assimilados reduzidas, que estão diretamente associadas ao fechamento dos estômatos (Huber, 1984). O movimento e abertura e fechamento dos estômatos dependem de vários fatores, entre eles da concentração de K nos tecidos (Hopkings, 1995 e Marschner, 1995). Portanto, na menor disponibilidade de $\mathrm{K}$ pode ocorrer $\mathrm{o}$ fechamento dos estômatos, levando à diminuição da difusão do vapor d'água para a atmosfera e da difusão do $\mathrm{CO}_{2}$ para o mesófilo foliar, com depressão da fotossíntese e da produtividade. Os resultados obtidos comprovam o papel do $\mathrm{K}$ no processo fotossintético, como mostram as Figura 14 e 15.

\subsection{Conclusões}

Dos resultados obtidos pode-se concluir que:

As doses excessivas de $\mathrm{N}$ utilizadas limitaram a fotossíntese. As doses intermediárias da adubação potássica interferiram positivamente nos parâmetros. O P teve pouca influência nos parâmetros avaliados.

No porta-enxerto limoeiro 'Cravo', a assimilação de $\mathrm{CO}_{2}$, transpiração, e eficiência do uso da água do foram relacionados com os teores foliares de $\mathrm{K}$.

Nas mudas de laranjeira 'Valência', a assimilação de $\mathrm{CO}_{2}$, e a eficiência do uso da água do foram relacionados positivamente com os teores foliares de $\mathrm{Ke}$ a concentração interna de $\mathrm{CO}_{2}$ negativamente. 


\section{TEORES E ACUMULAÇÃO DE MACRONUTRIENTES EM MUDAS DE CITROS CULTIVADAS EM VASOS EM FUNÇÃO DA ADUBAÇÃO COM NITROGÊNIO, FÓSFORO E POTÁSSIO}

\section{Resumo}

Cultivou-se em ambiente protegido mudas de laranjeira 'Valência' (Citrus sinensis L. Osbeck) sobre o porta-enxerto de limoeiro 'Cravo' (C. limonia Osbeck) em vasos de 3,8 L com substrato de casca de Pinus. Avaliou-se os efeitos do fornecimento de NPK, sobre os teores de macronutrientes do portaenxerto e das mudas. Utilizou-se um esquema de fatorial fracionário (1/5) $5^{3} \mathrm{com}$ um delineamento em 5 blocos casualisados. Os tratamentos ( $g$ por planta) consistiram em 5 doses de $\mathrm{N}: 1,25 ; 6,25 ; 11,25 ; 16,25 ; 21,25 ; 5$ doses de $\mathrm{K}$ : 0,$42 ; 3,75 ; 6,22 ; 9,34 ; 12,45$; e 5 doses de $P: 0,19 ; 0,89 ; 1,59 ; 2,29 ; 2,99$. N e K foram fornecidos semanalmente, sendo $37,5 \%$ da dose para o porta-enxerto e o restante para muda. O P foi fornecido todo no plantio. Determinou-se os teores totais de $\mathrm{N}, \mathrm{P}$ e K, Ca, $\mathrm{Mg}$ e S $\left(\mathrm{g} \mathrm{kg}^{-1}\right)$ nas folhas novas e velhas, raizes e caule (g por planta) para os porta-enxertos e as mudas. Estabeleceu-se a acumulação e a eficiência do uso de NPK. Foram ajustadas funções de resposta e os niveis de adubação para obterem-se os teores máximos foram calculados e discutidos, assim como as relações entre os nutrientes nos tecidos. A ordem decrescente dos teores de macronutrientes nos órgãos analisados foram: folhas velhas, folhas novas, raízes e caule. A adubação nitrogenada relacionou-se diretamente com os teores de $\mathrm{N}$ e inversamente como os de $\mathrm{P}$ e $\mathrm{K}$. Nos níveis intermediários de adubação nitrogenada o $\mathrm{N}$ relacionou-se positivamente com o $\mathrm{Ca}, \mathrm{Mg}$ e S. Houve efeito inibitório entre $\mathrm{K}$. 
Ca e Mg. A acumulação de NPK pelos porta enxertos foi em torno de $30 \%$ pelas raizes e $70 \%$ pela parte aérea.

\section{CONTAINERIZED CITRUS NURSERY TREES MACRONUTRIENTS CONCENTRATION AND EXTRACTION DUE TO NITROGEN, PHOSPHORUS AND POTASSIUM FERTILIZATION.}

\section{Summary}

'Valencia' sweet orange nursery trees (Citrus sinensis L. Osbeck) budded on Rangpur lime rootstocks (C. limonia Osbeck) were grown in a protected environment in $3,8 \mathrm{~L}$ containers with Pinus bark, vermiculite and perlite substract. NPK fertilization effect were evaluated. The experiment was carried out as a (1/5) $5^{3}$ factorial in a complete randomized block design. Treatments comprised (g per plant) five levels of $\mathrm{N}: 1.25 ; 6.25 ; 11.25 ; 16.25 ; 21.25$; five levels of $\mathrm{K}$ : $0.42 ; 3.75 ; 6.22 ; 9.34 ; 12.45$; and five levels of $P: 0.19 ; 0.89 ; 1.59 ; 2.29 ; 2.99$. Nitrogen and $K$ were applieded weekly, and $37.5 \%$ of the total fertilization was applied to rootstocks. All P was supplied at planting. Response functions were adjusted and nutrient rates for maximum yield are presented Young and old leaves, root and stem total nutrient concentrations of $\mathrm{N}, \mathrm{P}, \mathrm{K}, \mathrm{Ca}, \mathrm{Mg}$ and $\mathrm{S}$ and $\mathrm{N}, \mathrm{P}$ and $\mathrm{K}$ extraction were evaluated. Macronutrients tissue concentrations decreased in the following order: old leaves, young leaves, roots and stem. Nitrogen fertilization was directly related with tissue $\mathrm{N}$ concentration and inversely with $\mathrm{P}$ and $\mathrm{K}$ concentrations. Calcium, $\mathrm{Mg}$ and $\mathrm{S}$ concentrations increased until intermediate $\mathrm{N}$ fertilization rates. Inhibition of plant nutrient absorption occurred among $\mathrm{K}, \mathrm{Ca}$ and $\mathrm{Mg}$. Rootstocks $\mathrm{N}, \mathrm{P}$ and $\mathrm{K}$ accumulated around $30 \%$ in roots and $70 \%$ in shoot. 


\subsection{Introdução}

De acordo com Smith (1966), fatores como variedade, combinação copa e porta-enxerto, idade e posição das folhas nos ramos, e as interações entre os nutrientes podem interferir nos teores folhares dos citros. Porém, para Koo (1985), as interações são o fator predominante sobre os teores de nutrientes nas folhas.

Há várias interações relatadas entre os nutrientes nas plantas cítricas (Smith, 1966; Chapman, 1968 e Embleton et al., 1978). Geralmente, os teores de $\mathrm{N}$ e de $\mathrm{K}$ são inversamente relacionados, porém $0 \mathrm{~N}$ tem um papel predominante sobre o de $\mathrm{K}$. Alguns estudos utilizando fatoriais de $\mathrm{N}$ e de $\mathrm{K}$, mostraram que os altos niveis de $\mathrm{N}$ fornecidos resultaram em altos teores de $\mathrm{N}$ na folha e baixos teores de $\mathrm{K}$, porém o aumento nos niveis de $\mathrm{K}$ resultaram em aumento dos teores de $\mathrm{K}$ na folha, mas não interferiram nos teores de $\mathrm{N}$ (Reese \& Koo, 1975; Reitz \& Koo, 1960). Estes resultados, segundo Koo (1985) indicam que o $\mathrm{N}$ é o dominante na interação entre os dois nutrientes.

O N e o Mg na folha relacionam-se positivamente (Reese \& Koo, 1975; Koo \& Reese, 1977), pois existe uma relação sinergística entre eles (Smith, 1966).

Os teores de $\mathrm{P}$ nas folhas dependem do suprimento do nutriente, mas também do teor de $N$. Seus teores nas folha são inversamente relacionados, tendo o $N$ um efeito pronunciado sobre o P (Reese \& Koo, 1975). Plantas com teores baixos ou deficientes em $N$, poderão apresentar altos teores de $P$, quando há excesso de $N$ espera-se que haja teores baixos de $P$, sendo praticamente impossivel encontrar-se folhas com excesso de $\mathrm{N}$ e $\mathrm{P}$ ao mesmo tempo. (Smith, 1966).

O K e o Ca competem fortemente pelos mesmos sítios de absorção, e o excesso de um leva à redução na absorção do outro, mostrando um efeito de inibição competitiva. Altos teores de $\mathrm{K}$ também induzem à deficiência de $\mathrm{Mg}$, devido a inibição competitiva entre eles (Embleton et al., 1973; Chapman, 1968; 
Smith, 1966), porém o inverso não é tão intenso. Weir (1969), observou que o K foi o cátion mais fortemente inibidor. Confirmando a interação entre os nutrientes, Reese \& Koo (1975), em um estudo de adubação, observaram que os aumentos nos teores de $\mathrm{K}$ estavam associados com niveis altos de $\mathrm{P}$ e de $\mathrm{K}$, mas menores de $\mathrm{Ca}$ e de $\mathrm{Mg}$.

Koo \& Reese (1977) em seu estudo relacionaram algumas destas interações e demonstraram outras. $O$ fornecimento de $N$ resultou em concentrações foliares maiores do nutriente e de $\mathrm{Mg}$, reduzindo o $\mathrm{P}, \mathrm{Ke} \mathrm{Ca}$. As aplicações de $\mathrm{P}$ aumentaram as concentrações de $\mathrm{P}, \mathrm{K}$ e do $\mathrm{Ca}$ e reduziram as de Mg.

Essas interações entre os nutrientes passam a ser muito importantes no sistema de produção de mudas em vasos e em ambiente protegido, uma vez que o objetivo é a obtenção de mudas sadias e vigorosas no menor tempo possivel. Isso é conseguido através de fertilizações intensas, que buscam o desenvolvimento mais intenso das plantas. Porém, a literatura no Brasil discutindo produção, a adubação e a nutrição de mudas nesse sistema é ainda escassa'.

Existem trabalhos que discutiram estas relações em plantas adultas de citros. Trabalhando com laranjeira 'Baianinha' (C. sinensis), Gallo et al. (1960) observaram que, elevando-se a adubação potássica, houve elevação das concentrações foliares de $\mathrm{N}$ e de K. O P não foi alterado, porém $\circ \mathrm{Ca}$ e $\circ \mathrm{Mg}$ foram reduzidos, havendo pronunciada inibição competitiva entre $\circ \mathrm{K}$ e $\circ \mathrm{Mg}$ em condições de campo. Gallo et al. (1966) observaram um efeito quadrático do $\mathrm{N}$ sobre a produção e o teor foliar do nutriente.

Nagai et al. (1975), no Brasil, estudaram as relações entre os nutrientes determinados em folhas de café, citros e milho, em quatro tipos de solo, confirmando a inibição competitiva entre $\circ \mathrm{K}$ e $\circ \mathrm{Ca}$ e entre $\circ \mathrm{Ke} \circ \mathrm{Mg}$. Ca e K mostraram inibição competitiva em folhas de café e sinergismo em folhas de 
citros. $\mathrm{O} N$ e o $P$ tiveram efeito sinérgico em café e inibitório em citros. OP correlacionou-se positivamente com o K nas três culturas.

As funções que os nutrientes exercem no metabolismo vegetal determinam sua mobilidade ou sua redistribuição dentro da planta após haverem sido absorvidos e incorporados. Os macronutrientes $\mathrm{N}, \mathrm{P}$ e $\mathrm{K}$ tem alta mobilidade e redistribuem-se facilmente dentro da planta. Portanto, é de se esperar eles estejam disponiveis nos pontos de crescimento, uma vez que mesmo havendo deficiência no suprimento eles poderão ser mobilizados dos órgãos mais velhos e redistribuídos para os mais novos. Daí a importância de conhecer-se em quais órgãos da planta estes nutrientes estão localizados em maiores quantidades. Segundo Legaz et al. (1995), no caso de $N$, as maiores quantidades do nutriente foram encontradas nas folhas $(33-42 \%)$ e nas raízes $(30-38 \%)$. As folhas velhas são os principais órgãos de reserva, contribuindo com 40 a $50 \%$ das reservas totais de $\mathrm{N}$ exportado. As raizes e caule exportaram entre $30-35 \%$ e $15-25 \%$ das reservas totais de $\mathrm{N}$, respectivamente.

Apesar da tendência crescente na produção de mudas envasadas em ambiente protegido, conforme exigência do sistema de produção de mudas certificadas de citros do Estado de São Paulo, existem ainda poucos estudos relacionando os efeitos das adubações NPK sobre as interações entre os nutrientes e a acumulação plantas nestas condições.

O objetivo desse trabalho foi avaliar os efeitos da adubação NPK, sobre os teores de macronutrientes do porta-enxerto e das mudas, bem como determinar a acumulação e a eficiência de uso de NPK.

\subsection{Material e Métodos}

O experimento foi conduzido em viveiro demonstrativo do sistema de produção de mudas certificadas de citros, no Centro de Citricultura "Sylvio Moreira", do Instituto Agronômico - IAC, em Cordeirópolis-SP. Os detalhes do 
viveiro são apresentados por Carvalho \& Laranjeira (1994). As características químicas do substrato, o delineamento experimental, tratamentos, instalação $e$ condução do experimento são os mesmos descritos nos itens 3.2.1 a 3.2.3.

\subsubsection{Amostragem}

Amostrou-se as folhas novas (não expandidas) e velhas (totalmente expandidas), raízes, e caule do limoeiro 'Cravo' e das mudas de laranjeira 'Valência'r'Cravo'.

\subsubsection{Determinação dos teores totais de nutrientes nos tecidos}

A obtenção dos extratos e determinações dos teores totais seguiram a metodologia descrita por Sarruge \& Haag (1974). Após digestão sulfúrica do material o $\mathrm{N}$ foi determinado pelo método semi-micro Kjedahl. No extrato obtido da digestão nítrico-perclórica determinou-se $P$ por colorimetria de vanadato molibdato, o $\mathrm{K}$ por fotometria de chama, $\mathrm{Ca}$ e $\mathrm{Mg}$, por espectrofotometria de absorção atômica e o $\mathrm{S}$ por densometria. A partir das análises, foram obtidos os teores totais de $\mathrm{N}, \mathrm{P}, \mathrm{K}, \mathrm{Ca}, \mathrm{Mg}$ e $\mathrm{S}\left(\mathrm{g} \mathrm{kg}^{-1}\right)$ e realizou-se o cálculo da acumulação de NPK.

\subsubsection{Análise estatística}

A análise de variância realizada seguiu os mesmos procedimentos descritos no item 3.2.4. Nas Tabelas 4, 5 e 6 estão os coeficientes da regressão em função das doses de $N, P$ e K. As análises estatísticas foram realizadas utilizando o programa estatístico SAS (SAS Institute, 1996). Quando as respostas foram significativas apenas para 1 ou 2 nutrientes, as funções foram simplificadas considerando-se os níveis menores dos demais nutrientes (Tabelas 7, 8 e 9). Determinou-se os teores máximos de nutrientes do cálculo $d x / d y=0$. 


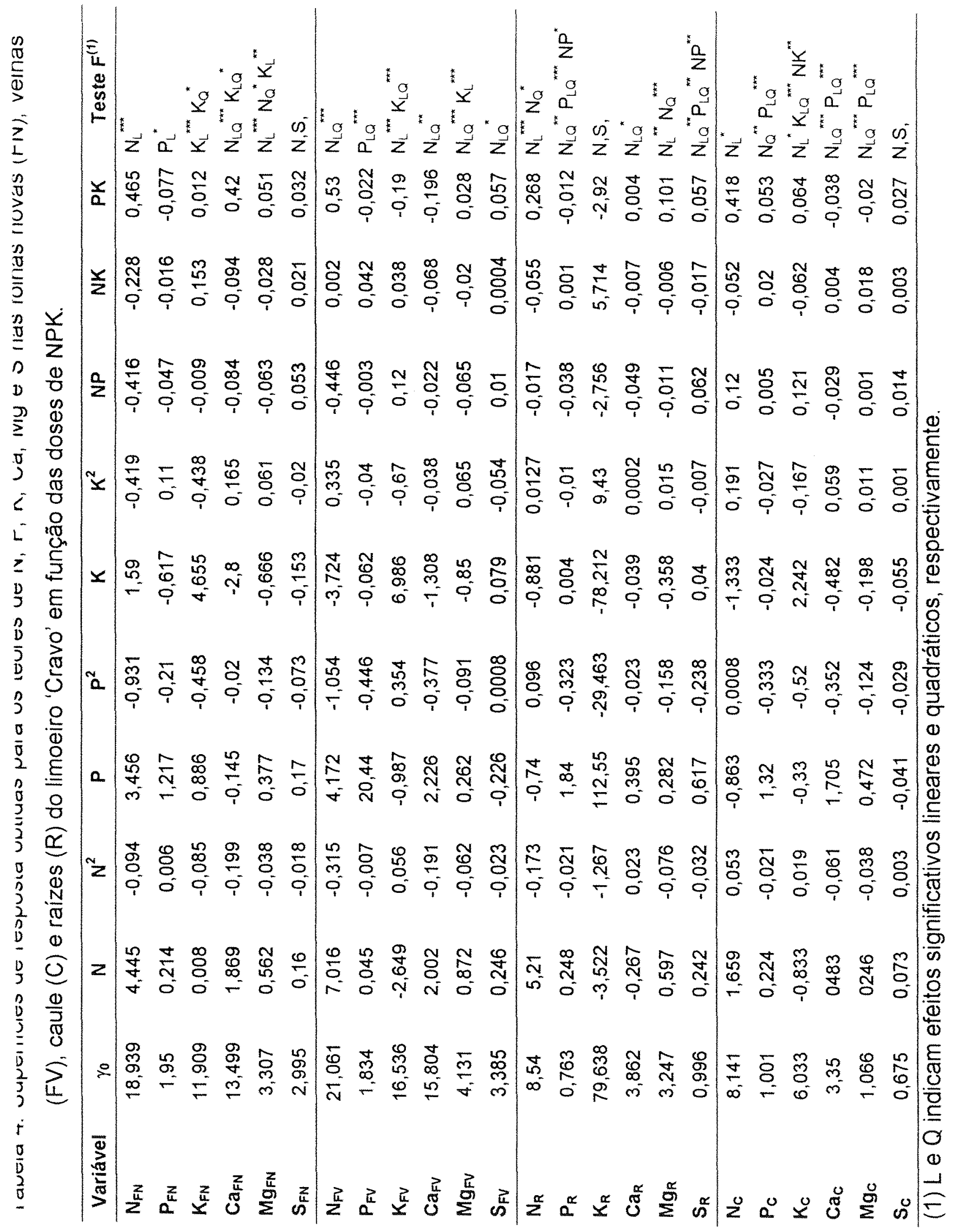




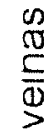

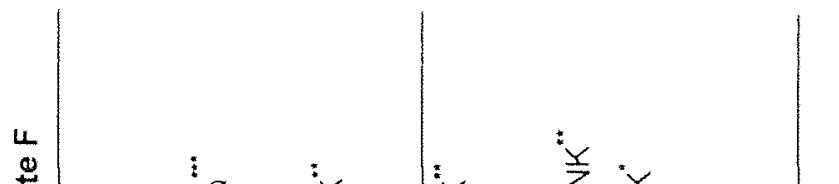

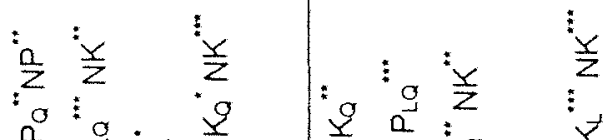

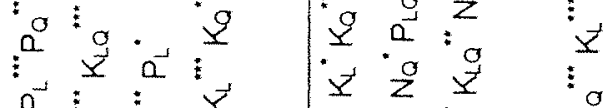

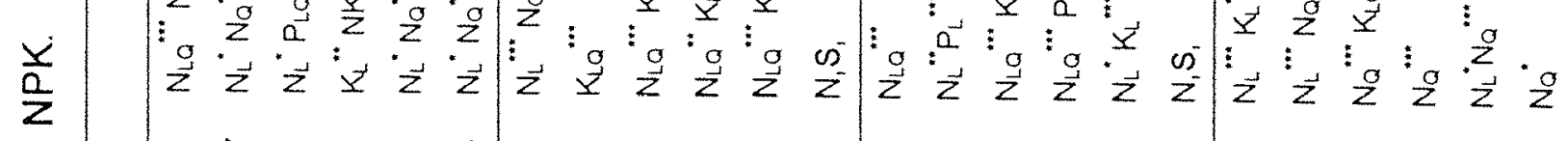

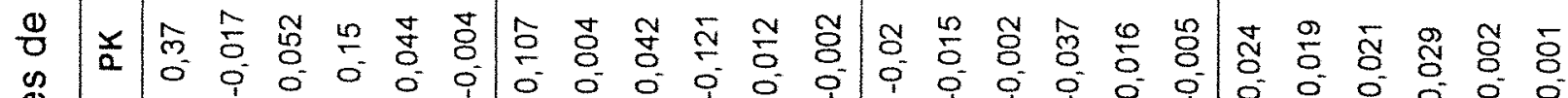

a

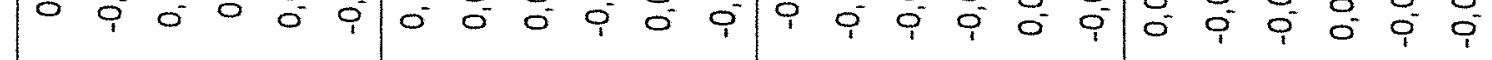

幽

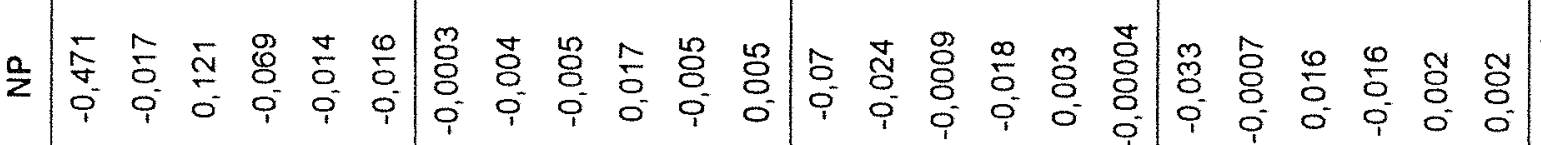

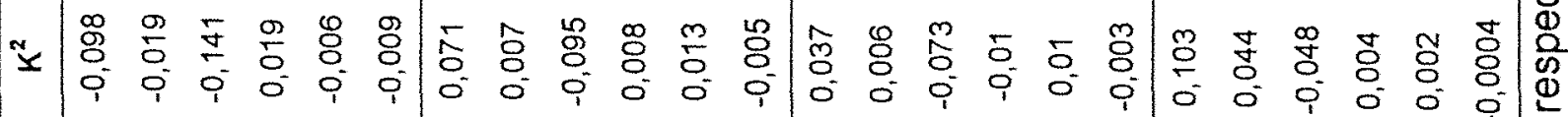

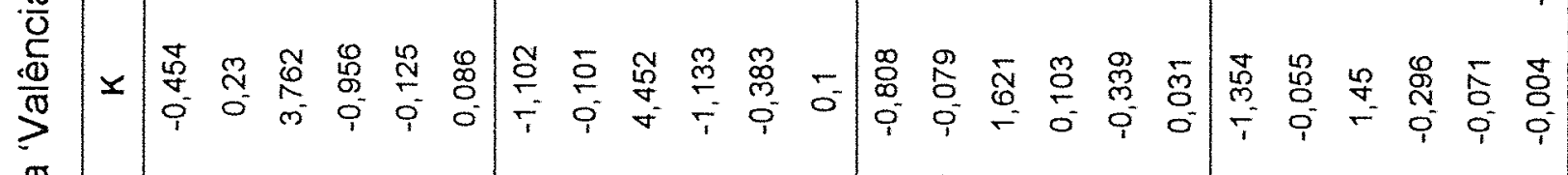

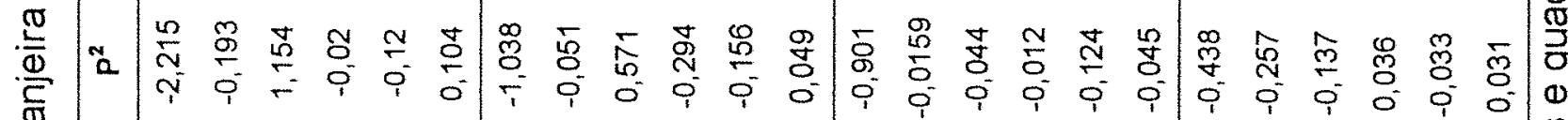

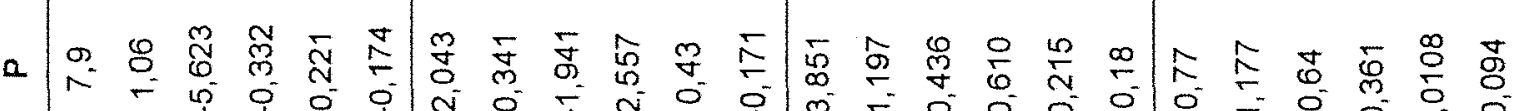

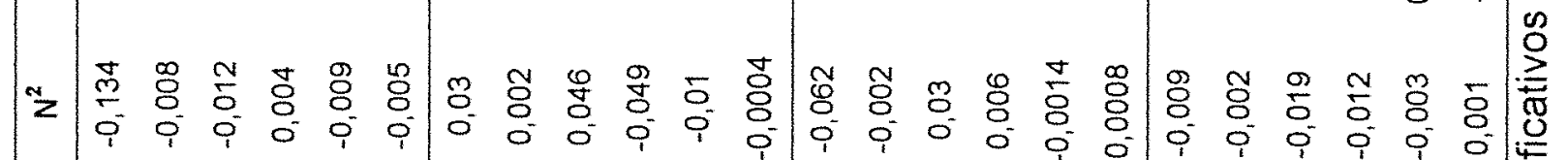

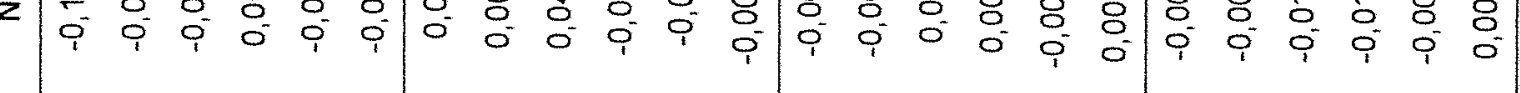

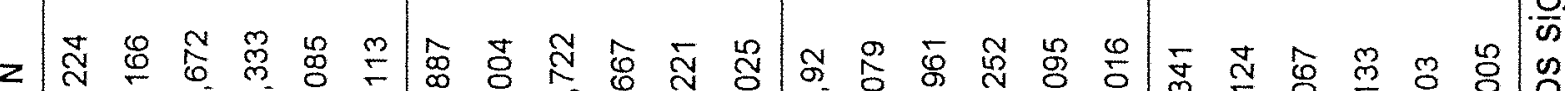

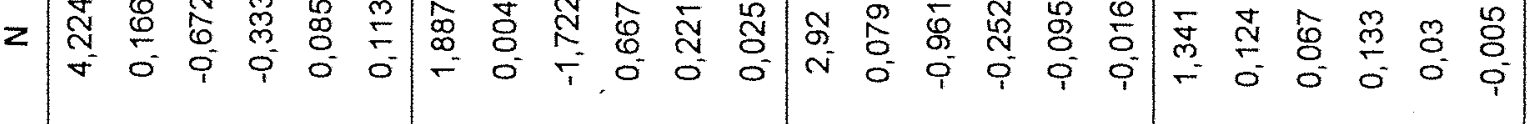
$\frac{\frac{6}{0}}{\frac{0}{2}}$

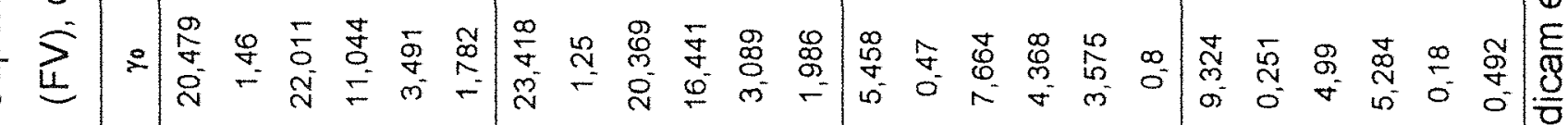




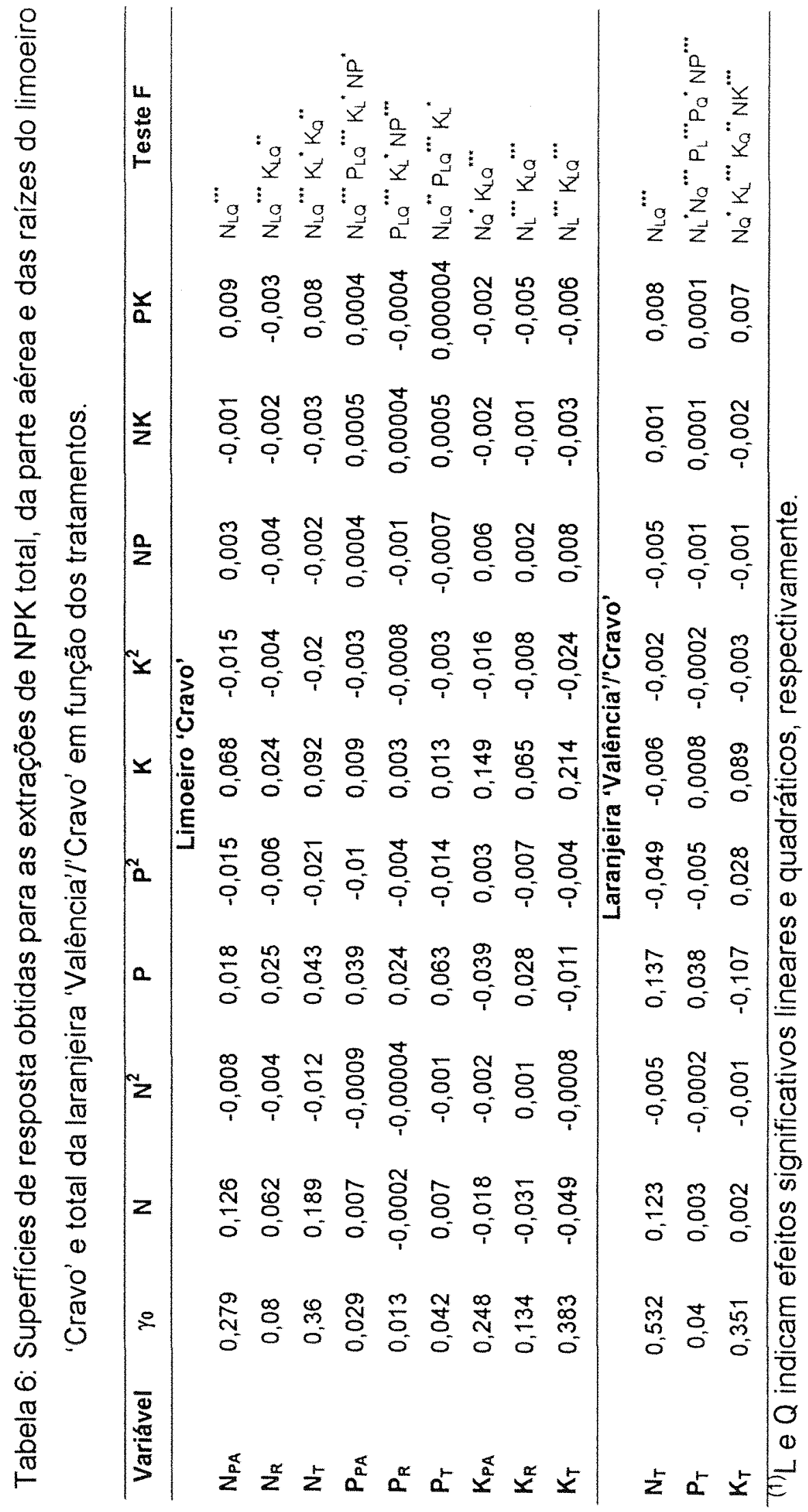




\subsection{Resultados e Discussão}

A utilização de experimentos fatoriais possibilita detectar e medir as interações entre os tratamentos. As análises dos diversos tecidos amostrados (folhas novas e velhas, raizes e caules) mostraram numerosas interações.

\subsubsection{Teores de nutrientes nos tecidos}

No cultivo do porta-enxerto limoeiro 'Cravo', a adubação nitrogenada aumentou linearmente os teores de $\mathrm{N}$ nos tecidos dentro dos limites testados (de 0,47 a 7,99 g por planta de $\mathrm{N}$ ). Os teores de $\mathrm{N}$ encontrados nos tecidos analisados seguiram a seguinte ordem decrescente: $\mathrm{FV}>\mathrm{FN}>$ Raízes $>$ Caule (Figura 16A).

Nas mudas de laranjeira 'Valência'/Cravo', houve efeito quadrático das doses de $\mathrm{N}$ sobre os teores do nutriente nas folhas novas, sendo que os teores máximos de $54,35 \mathrm{~g} \mathrm{~kg}^{-1}$, foram obtidos na dose de $15,6 \mathrm{~g}$ por planta (equação da Tabela 8). Gallo et al. (1966) observaram efeito semelhante nas folhas da laranjeira 'Baianinha'. Nas raízes, dentro dos limites testados $(1,25$ a 21,25 g) os aumentos foram lineares. Resultados semelhantes aos encontrados por Smith et al. (1953). Houve interação entre a adubação com $\mathrm{N}$ e K sobre os teores de $\mathrm{N}$ nas folhas velhas e caule, o fornecimento de $N$ aumentou linearmente os teores no nutrientes nesses tecidos. Porém o $\mathrm{K}$ atuou negativamente, e os efeitos foram mais intensos nos teores mais altos de $\mathrm{N}(21,25 \mathrm{~g}$ por planta), quando o aumento das doses de $\mathrm{K}$ de 0,42 para $12,45 \mathrm{~g}$ fez com que os teores de $\mathrm{N}$ reduzissem-se de 76,35 para $56,43 \mathrm{~g} \mathrm{~kg}^{-1}$ (Figura 16B). A equação da Tabela 8 mostra que no caule o efeito foi o mesmo, até o nivel de 6,91 g por planta, quando, então, os teores de $\mathrm{N}$ voltaram a aumentar.

O papel das folhas velhas como órgãos de reserva foi proposto por vários autores (Smith \& Reuther, 1950; Walace et al., 1954; Kato, 1986; Legaz et al., 1995) que observaram reduções na concentração do $N$ total desses órgãos nas fases de vegetação subseqüentes. Os resultados destes autores 
sugerem que o armazenamento do $\mathrm{N}$ é importante para as novas vegetações. Feiganbaum et al. (1987) sugere que o $\mathrm{N}$ acumulado poderia ser mobilizado tanto das reservas das partes lenhosas das plantas como das folhas novas e velhas.

Neste estudo observou-se que os teores de $\mathrm{N}$ nas folhas velhas tanto do porta-enxerto como das mudas, foram maiores que nos demais tecidos analisados, confirmando o papel destas como reservatório desse nutriente.
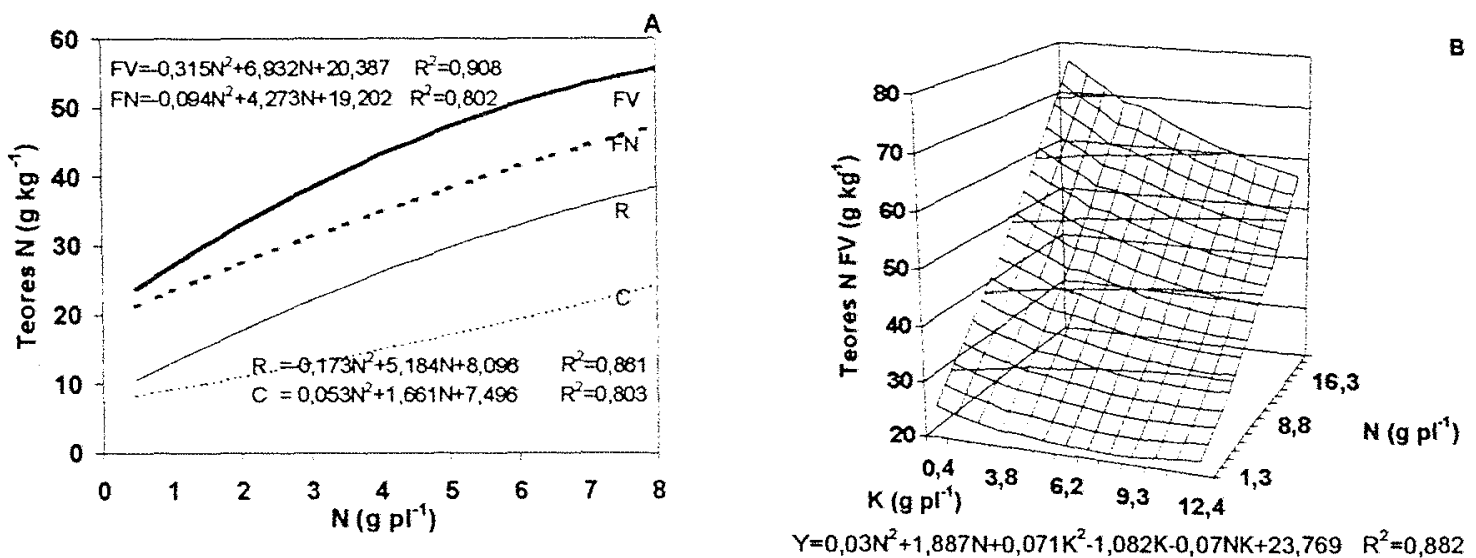

Figura 16: Teores de N no limoeiro 'Cravo' (A) e laranjeira 'Valência'l'Cravo' (B).

Nas folhas novas e velhas do porta-enxerto, os teores de $P$ aumentaram de $2,20 \mathrm{~g} \mathrm{~kg}^{-1}$ na dose mínima do nutriente $(0,19 \mathrm{~g}$ por planta de $\mathrm{P})$ até 4,42 e

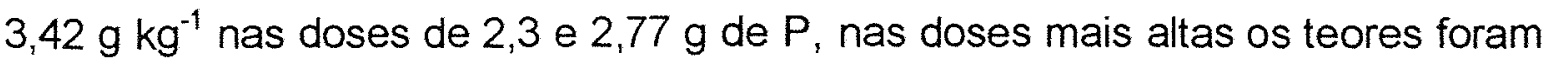
reduzidos como pode ser visto na Figura 17A. Nas raízes e no caule houve interação da adubação com $\mathrm{N}$ e $\mathrm{P}$, sobre os teores de $\mathrm{P}$. Pode-se observar o efeito quadrático dos nutrientes, sendo que os maiores teores $\left(3,39\right.$ e $\left.2,97 \mathrm{~g} \mathrm{~kg}^{-1}\right)$ foram obtidos nas doses de 2,86 e 4,25g de $\mathrm{N}$ e 2,78 e 1,87g de $P$, respectivamente. Aumentos nas doses de ambos nutrientes resultaram em diminuição dos teores de P nos tecidos (Tabela 7). 
Nas mudas, os teores de $P$ nas folhas velhas foram influenciados pela adubação potássica, que reduziu os teores de 1,27 para $0,95 \mathrm{~g} \mathrm{~kg}^{-1}$, da menor dose para a dose de $7,61 \mathrm{~g}$ por planta de $\mathrm{K}$. Doses maiores voltaram a elevar os teores do nutriente. Por outro lado, Gallo et al. (1960) não haviam observado efeito da adubação potássica sobre os teores de $P$ nas folhas de laranjeira 'Baianinha'. Houve interação entre o $\mathrm{N}$ e $\mathrm{P}$ fornecidos sobre os teores do nutriente nas folhas novas, raizes e caule. A Figura 17B ilustra estas interações nas folhas e pode-se observar que o teor foi máximo $\left(3,55 \mathrm{~g} \mathrm{~kg}^{-1}\right)$ nas doses de $8,01 \mathrm{~g} \mathrm{de} \mathrm{N}$ e 2,38 g de $P$. Pelas equações apresentadas na Tabela 8, pode-se observar que nas raizes os aumentos dos teores relacionaram-se diretamente com as doses de $P$, já as relações com $N$ foram positivas nos niveis mais baixos de $P$ e negativas nos níveis máximos. $\mathrm{O}$ teor máximo de $3,86 \mathrm{~g} \mathrm{~kg}^{-1}$ foi obtido na dose mínima de $\mathrm{N}$ e máxima de $\mathrm{P}(0,47$ e 2,99 g por planta, respectivamente). Já no caule os teores foram diretamente relacionados aos teores de $\mathrm{N}$, e aumentaram até $2,24 \mathrm{~g}$ de $\mathrm{P}$, quando obteve-se $3,27 \mathrm{~g} \mathrm{~kg}^{-1}$.
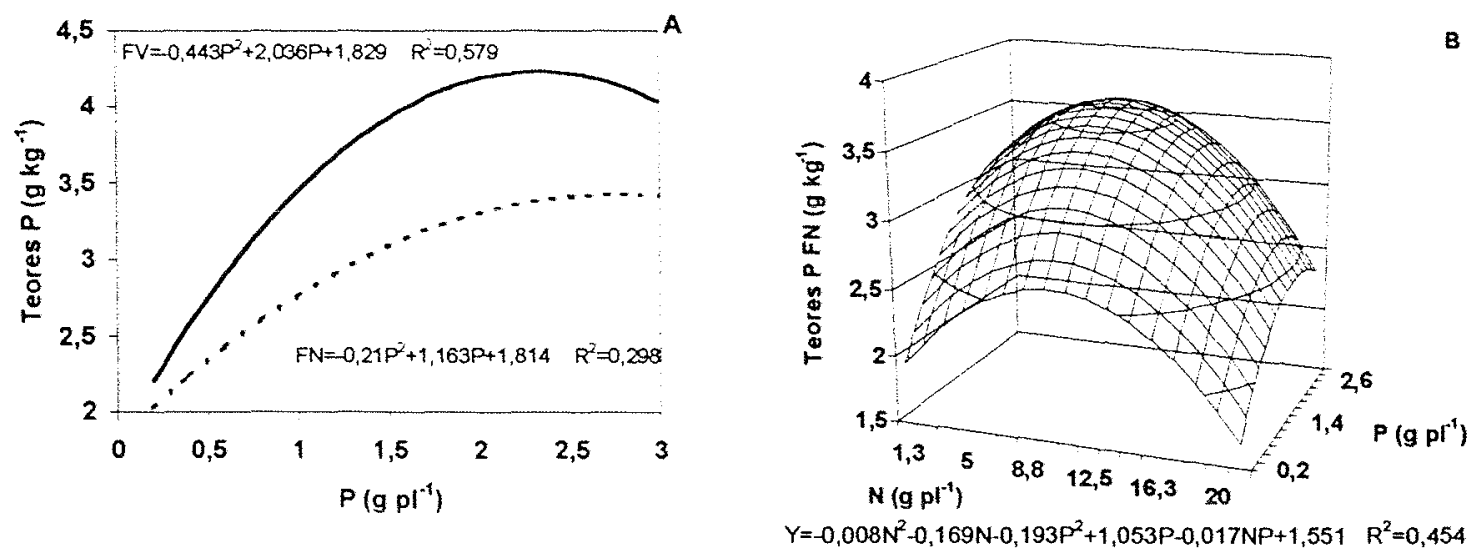

Figura 17: Teores de P no limoeiro 'Cravo' (A) e laranjeira 'Valência'l'Cravo' (B). 
Tabela 7: Função de resposta ajustada para os termos significativos obtidos para o limoeiro 'Cravo'. As condições indicam os níveis dos nutrientes não significativos para os quais as equações foram ajustadas.

\begin{tabular}{|c|c|c|c|}
\hline Variável & Equação & Condição $(\mathrm{g})$ & $\mathrm{R}^{2}$ \\
\hline$N_{\mathbf{F N}}$ & $Y=-0,094 N^{2}+4,273 N+19,202$ & $P=0,19$ e $K=0,42$ & 0,802 \\
\hline$P_{F N}$ & $Y=0,21 P^{2}+1,163 P+1,814$ & $N=0,47$ e $K=0,42$ & 0,298 \\
\hline$K_{F N}$ & $Y=-0,438 K^{2}+4,732 K+12,178$ & $N=0,47$ e $P=0,19$ & 0,784 \\
\hline $\mathrm{Ca}_{\mathrm{FN}}$ & $Y=-0,199 \mathrm{~N}^{2}+1,853 \mathrm{~N}+0,165 \mathrm{~K}^{2}-2,72 \mathrm{~K}-0,094 \mathrm{NK}+13,471$ & $P=0,19$ & 0,655 \\
\hline Mgrw & $Y=-0,038 N^{2}+0,55 N+0,061 K^{2}-0,676 K-0,08 N K+3,374$ & $P=0,19$ & 0,634 \\
\hline$N_{F V}$ & $Y=-0,315 N^{2}+6,932 N+20,387$ & $\mathrm{P}=0,19$ e $\mathrm{K}=0,42$ & 0,908 \\
\hline$P_{\text {Fv }}$ & $Y=-0,0045 P^{2}+20,43 P+1,816$ & $N=0,47$ e $K=0,42$ & 0,579 \\
\hline $\mathrm{K}_{\mathrm{FV}}$ & $Y=-0,056 N^{2}-2,672 N-0,67 K^{2}+6,95 K-0,038 N K+16,361$ & $P=0,19$ e $K=0,42$ & 0,892 \\
\hline $\mathrm{Ca}_{\mathrm{Fv}}$ & $Y=-0,191 N^{2}+1,97 N+15,656$ & $P=0,19$ e $K=0,42$ & 0,549 \\
\hline Mgrv & $Y=-0,062 N^{2}+0,86 N+0,065 K^{2}-0,845 K-0,02 N K+4,174$ & $P=0,19$ & 0,796 \\
\hline$S_{\text {rv }}$ & $Y=-0,023 N^{2}+0,248 N+3,37$ & $P=0,19$ e $K=0,42$ & 0,326 \\
\hline$N_{R}$ & $Y=-0,173 N^{2}+5,184 N+8,096$ & $P=0,19$ e $K=0,42$ & 0,861 \\
\hline$P_{R}$ & $Y=-0,021 N^{2}+0,225 N-0,323 P^{2}+1,785 P-0,038 N P+0,763$ & $K=0,42$ & 0,841 \\
\hline $\mathrm{Ca}_{\mathrm{R}}$ & $Y=0,023 N^{2}-0,279 N+3,921$ & $P=0,19$ e $K=0,42$ & 0,468 \\
\hline $\mathrm{Mg}_{\mathrm{R}}$ & $Y=-0,076 \mathrm{~N}^{2}+0,592 \mathrm{~N}+3,159$ & $P=0,19$ e $K=0,42$ & 0,352 \\
\hline$S_{R}$ & $Y=-0,032 N^{2}+0,246 N-0,238 P^{2}+0,628 P-0,062 N P+1,01$ & $K=0,42$ & 0,57 \\
\hline$N_{c}$ & $Y=0,053 N^{2}+1,661 N+7,496$ & $P=0,19$ e $K=0,42$ & 0,803 \\
\hline$P_{c}$ & $Y=-0,021 N^{2}+0,232 N-0,333 P^{2}+1,342 P-0,029 N P+3,16$ & $K=0,42$ & 0,779 \\
\hline $\mathrm{K}_{\mathrm{c}}$ & $Y=0,019 N^{2}-0,883 N-0,167 K^{2}-2,23 K-0,062 N K-0,0485$ & $P=0,19$ & 0,943 \\
\hline $\mathrm{Ca}_{\mathbf{c}}$ & $Y=-0,061 N^{2}+0,485 N-0,352 P^{2}+1,721 P-0,029 N P+3,16$ & $K=0,42$ & 0,589 \\
\hline $\mathrm{Mgc}$ & $Y=-0,038 N^{2}+0,253 N-0,124 P^{2}-0,046 P-0,001 N P+0,987$ & $K=0,42$ & 0,693 \\
\hline
\end{tabular}


Tabela 8: Função de resposta ajustada para os termos significativos obtidos para a laranjeira 'Valência'l'Cravo'. As condições indicam os níveis dos nutrientes não significativos para os quais as equações foram ajustadas.

\begin{tabular}{|c|c|c|c|}
\hline Variável & Equação & Condição (g) & $\mathrm{R}^{2}$ \\
\hline$N_{\text {FN }}$ & $Y=-0,134 N^{2}+4,182 N+21,726$ & $P=0,19$ e $K=0,42$ & 0,918 \\
\hline$P_{F N}$ & $Y=-0,008 N^{2}+0,169 N-0,193 P^{2}+1,053 P-0,017 N P+1,551$ & $K=0,42$ & 0,454 \\
\hline$K_{F M}$ & $Y=1,154 P^{2}-3,052 P-0,141 K^{2}+, 3,868 K+0,052 N K+2,312$ & $P=0,19$ & 0,935 \\
\hline CapN & $Y=0,004 N^{2}+0,351 N+0,019 K^{2}-0,927 K+0,03 N K+10,977$ & $P=0,19$ & 0,776 \\
\hline MgFN & $Y=-0,009 N^{2}+0,082 N-0,006 K^{2}-0,117 K+0,007 N K+3,51$ & $P=0,19$ & 0,703 \\
\hline $\mathrm{S}_{\mathrm{FN}}$ & $Y=-0,005 N^{2}+0,112 N+1,786$ & $P=0,19$ e $K=0,42$ & 0,166 \\
\hline$N_{\text {Fv }}$ & $Y=0,03 N^{2}+1,887 N+0,071 K^{2}-1,082 K-0,07 N K+23,769$ & $P=0,19$ & 0,882 \\
\hline Prv & $Y=0,007 K^{2}-0,101 K+1,315$ & $N=0,47$ e $P=0,19$ & 0,645 \\
\hline $\mathrm{K}_{\mathrm{Fv}}$ & $Y=0,046 N^{2}-1,723 N-0,095 K^{2}+4,46 K-0,042 N K+20,109$ & $P=0,19$ & 0,828 \\
\hline Carv & $Y=-0,094 N^{2}+0,67 N+0,008 K^{2}-1,156 K+0,029 N K+16,871$ & $P=0,19$ & 0,813 \\
\hline Mgrv & $Y=-0,01 N^{2}+0,22 N-0,013 K^{2}-0,381 K+0,002 N K+3,141$ & $P=0,19$ & 0,67 \\
\hline$N_{R}$ & $Y=-0,062 N^{2}+2,91 N+5,693$ & $P=0,19$ e $K=0,42$ & 0,803 \\
\hline$P_{R}$ & $Y=-0,002 N^{2}+0,079 N-0,016 P^{2}+1,191 P-0,024 N P+0,439$ & $K=0,42$ & 0,706 \\
\hline$K_{R}$ & $Y=0,03 N^{2}-0,961 N-0,073 K^{2}+1,621 K-0,029 N K+7,745$ & $P=0,19$ & 0,868 \\
\hline $\mathrm{Ca}_{\mathrm{R}}$ & $Y=0,006 N^{2}-0,25 N-0,012 P^{2}+0,595 P-0,018 N P+4,406$ & $P=0,19$ & 0,518 \\
\hline $\mathrm{Mg}_{\mathrm{R}}$ & $Y=-0,0014 N^{2}-0,094 N+0,01 K^{2}-0,336 K+0,009 N K+3,611$ & $P=0,19$ & 0,654 \\
\hline $\mathrm{N}_{c}$ & $Y=-0,009 N^{2}+1,335 N+0,103 K^{2}-1,349 K-0,001 N K+9,454$ & $P=0,19$ & 0,803 \\
\hline$P_{c}$ & $Y=-0,002 N^{2}+0,124 N-0,254 P^{2}+1,169 P-0,0007 N P+0,246$ & $K=0,42$ & 0,706 \\
\hline $\mathrm{K}_{\mathrm{c}}$ & $Y=-0,019 N^{2}+0,07 N-0,048 K^{2}+1,45 K-0,024 N K+5,107$ & $P=0,19$ & 0,868 \\
\hline $\mathrm{Cac}$ & $Y=-0,012 N^{2}+0,133 N+5,241$ & $P=0,19$ e $K=0,42$ & 0,518 \\
\hline Mge & $Y=-0,003 N^{2}+0,03 N+0,02 K^{2}-0,071 K+0,003 N K+0,176$ & $P=0,19$ & 0,654 \\
\hline $\mathrm{S}_{\mathrm{c}}$ & $Y=0,001 N^{2}-0,003 N+0,474$ & $P=0,19$ e $K=0,42$ & 0,704 \\
\hline
\end{tabular}

De acordo com Smith (1966), o efeito contrário do $\mathrm{N}$ é muito forte sobre o $P$, porém o inverso não é tão evidente. Os resultados obtidos para os portaenxertos e para as mudas confirmam que o adubo fosfatado não interferiu nos teores de $\mathrm{N}$, porém o adubo nitrogenado nos níveis mais altos reduziu os teores de P. Nagai et al. (1975); Reese \& Koo (1975) e Koo \& Reese (1977) também 
observaram o efeito inibitório do $\mathrm{N}$ sobre o $\mathrm{P}$ apenas nas folhas de citros e Smith et al. (1953) nas folhas e raizes.

Dentro dos limites testados da adubação potássica na produção dos portaenxertos, os teores de $\mathrm{K}$ nas folhas novas foram lineares e aumentaram de 14,09 a $24,72 \mathrm{~g} \mathrm{~kg}^{-1}$ da menor para a maior dose $(0,42$ para $4,67 \mathrm{~g}$ por planta) (Tabela 7). Houve interação entre $\mathrm{N}$ e $\mathrm{K}$ sobre os teores de $\mathrm{K}$ nas folhas velhas e colmo. $A$ Figura 18A mostra que o $\mathrm{N}$ do fertilizante decresceu os teores de $\mathrm{K}$, já o $\mathrm{K}$ do fertilizante aumentou linearmente os teores do nutriente. O maior teor $(33,05 \mathrm{~g}$ $\left.\mathrm{kg}^{1}\right)$ foi obtido na menor dose de $\mathrm{N}(0,47 \mathrm{~g}$ por planta) e na maior dose de $\mathrm{K}$ (4,67g por planta). No caule os teores de $K$, cresceram até $1,81 \mathrm{~g}$ por planta de $\mathrm{K}$ e então voltaram a decrescer, e o adubo nitrogenado teve também um papel negativo sobre os teores (Tabela 7 ). Os teores de $\mathrm{K}$ nas raízes não relacionaramse com os tratamentos.

Nas mudas, a relação entre a adubação potássica e os teores de $\mathrm{K}$ nas folhas novas foram diretas, e aumentaram até $28,2 \mathrm{~g} \mathrm{~kg}^{-1} \mathrm{com}$ o fornecimento de $12,45 \mathrm{~g}$ por planta de K. Houve interação entre a fertilização com N e K nos teores de $K$ das folhas velhas, raízes e colmo. Nas folhas velhas, a relação foi inversa, sendo que o $\mathrm{N}$ influenciou negativamente e $\circ \mathrm{K}$ positivamente, por isso o teor máximo de $58,17 \mathrm{~g} \mathrm{~kg}^{-1}$ foi obtido com 1,25 e 12,45 g por planta de $\mathrm{N}$ e de $\mathrm{K}$, respectivamente (Figura 18B). Nas raizes e caule, o $N$ também reduziu os teores de $\mathrm{K}$. Porém, os maiores teores $\left(14,39\right.$ e $\left.15,40 \mathrm{~g} \mathrm{~kg}^{-1}\right)$ foram obtidos nas doses mínimas de $\mathrm{N}(1,25 \mathrm{~g})$ e de 7,23 e 12,45 g por planta de $\mathrm{K}$, para as raízes e caule, respectivamente (Tabela 8). Reese \& Koo (1975) e Reitz \& Koo (1960) também demonstraram estas relações entre $\mathrm{N}$ e $\mathrm{K}$ nas folhas de citros e Smith et al. (1954) além das folhas, nas raízes. 


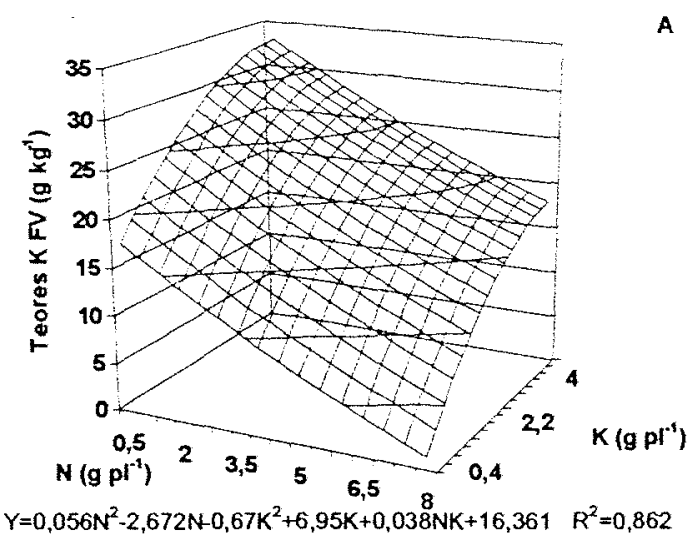

$Y=0,056 N^{2}-2,672 N-0,67 K^{2}+6,95 K+0,038 N K+16,361 \quad R^{2}=0,862$

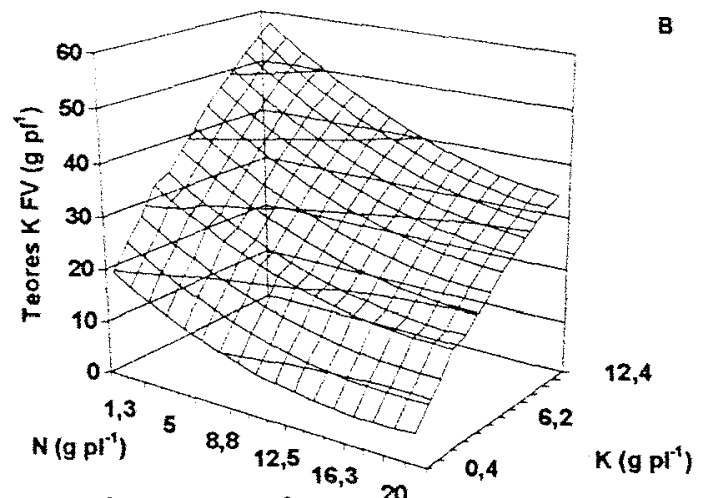

$Y=0,046 N^{2}-1,723 N-0,095 K^{2}+4,46 K-0,042 N K+20,109 \quad R^{2}=0,828$

Figura 18: Teores de K no limoeiro 'Cravo' (A) e laranjeira 'Valência'l'Cravo' (B).

Nas folhas velhas do limoeiro 'Cravo', da doses mais baixa de $\mathrm{N}(0,47 \mathrm{~g}$ por planta) para a dose de 5,16 g por planta, os teores de $\mathrm{Ca}$ aumentaram de 16,54 para $20,74 \mathrm{~g} \mathrm{~kg}^{-1}$, depois voltaram a decrescer. O mesmo ocorreu nas folhas novas, porém houve interação negativa com o K. O teor mais alto, 15,67 $\mathrm{g} \mathrm{kg}^{-1}$ foi obtido com 2,55 g por planta de $\mathrm{N}$ e 0,42 $\mathrm{g}$ por planta de $\mathrm{K}$ e os acréscimos nas doses de $\mathrm{K}$ reduziram os teores de $\mathrm{Ca}$. $\mathrm{O}$ efeito observado nas raizes foi inverso ao das folhas, sendo observada uma redução nos teores de Ca de 3,79 para 3,07 $\mathrm{g} \mathrm{kg}^{-1}$ da dose mínima para a doses de 6,07 g por planta de N. As equações que representam estas relações estão na Tabela 7.

Para os teores de $\mathrm{Ca}$ das folhas novas e velhas das mudas de laranjeira 'Valência'P'Cravo' houve interação entre N e K. Os maiores teores de Ca $(10,71 \mathrm{~g}$ $\mathrm{kg}^{-1}$ ) nas folhas novas foram obtidos com 1,25 e 0,42 g por planta de $\mathrm{N}$ e de $\mathrm{K}$. No entanto o $N$ apresentou um papel diferenciado tendo sido depressivo nas menores doses de $K$. Já nas maiores doses de $K$ foi benéfico até $6,99 \mathrm{~g}$ por planta, quando passou a ter efeito depressivo. A Figura 19A representa estas interações. Nas folhas velhas o adubo potássico sempre atuou negativamente, e o adubo nitrogenado foi benéfico até $12,77 \mathrm{~g}$ por planta, quando obteve-se o teor 
de Ca $\left(17,11 \mathrm{~g} \mathrm{~kg}^{-1}\right)$. Nas raízes observou-se interação entre $\mathrm{N}$ e de $\mathrm{P}$, sendo que o $P$ foi benéfico e o $N$ não. Estes resultados confirmam os de Smith (1975), segundo os quais o $\mathrm{K}$ não interferiu nos teores de Ca das raízes. Nas doses de 1,25 e 2,99 g por planta de $\mathrm{N}$ e $\mathrm{P}$, obteve-se o teor de $5,71 \mathrm{~g} \mathrm{~kg}^{-1}$. Nos teores de Ca do caule o $\mathrm{N}$ teve papel benéfico até $5,54 \mathrm{~g}$ por planta (Tabela 8)

Koo \& Reese (1977) observaram que a adubação nitrogenada reduziu os teores de $\mathrm{Ca}$, efeito que ocorreu nesse estudo apenas nas doses mais elevadas de fertilizante nitrogenado. A inibição competitiva existente entre $\mathrm{Ke} \mathrm{Ca} \mathrm{já} \mathrm{havia}$ sido relatada em vários estudos (Gallo et al., 1960; Smith, 1966; Chapman, 1968; Weir, 1969; Nagai et al., 1975; Smith, 1975; Koo \& Reese, 1977; Embleton et al., 1978).
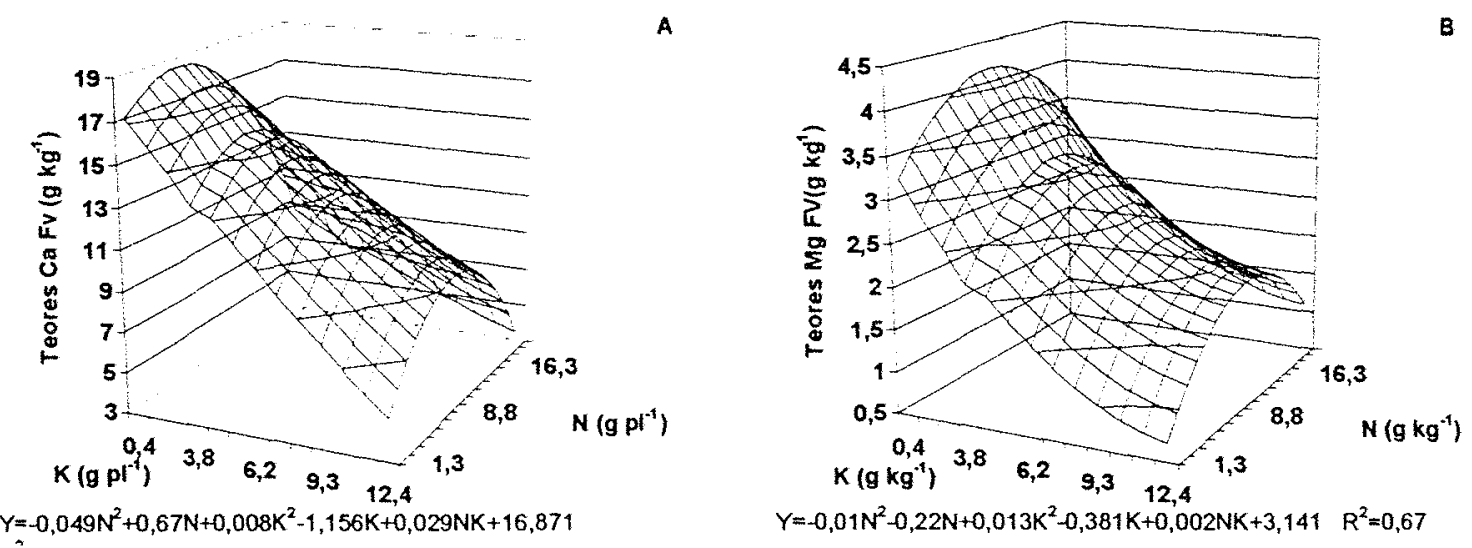

Figura 19: Teores de Ca (A) e Mg (B) na laranjeira 'Valência'l'Cravo'.

$\mathrm{Na}$ adubação dos porta-enxertos, houve interação entre o fornecimento de $\mathrm{N}$ e de $\mathrm{K}$ sobre os teores de $\mathrm{Mg}$ nas folhas novas e folhas velhas. $\mathrm{O} \mathrm{K}$ reduziu os teores, enquanto o $\mathrm{N}$ teve efeito positivo até as doses de 4,8 e 5,74 g por planta de $\mathrm{N}$. Os teores máximos $\left(4,81\right.$ e 6,68 $\left.\mathrm{g} \mathrm{kg}^{-1}\right)$ foram obtidos na dose mínimas de $\mathrm{K}$ $(0,42 \mathrm{~g}$ por planta). Para os teores de $\mathrm{Mg}$ do caule, houve interação entre $\mathrm{N}$ e $\mathrm{P}$, 
tendo estes nutrientes apresentado efeito positivo e quadrático sobre os teores. Nas doses de 3,3 e 1,87 g por planta de $N$ e de $P$, obteve-se o maior teor (de 1,87 $\mathrm{g} \mathrm{kg}^{-1}$ ). $\mathrm{O}$ adubo nitrogenado teve efeito positivo quadrático sobre os teores de $\mathrm{Mg}$ nas raizes, e o na dose de $3,9 \mathrm{~g}$ por planta de $\mathrm{N}$ alcançou-se o teor de $4,31 \mathrm{~g} \mathrm{~kg}^{-1}$ (Tabela 7).

$\mathrm{Na}$ adubação das mudas, também houve interação entre $\mathrm{N}$ e K sobre os teores de $\mathrm{K}$ nas folhas novas e velhas. $\mathrm{O}$ adubo potássico atuou negativamente, enquanto que o $\mathrm{N}$ positivamente até as doses de 9,13 e 12,4 g por planta, enquanto que nas doses mais baixas de $\mathrm{K}(0,42 \mathrm{~g}$ por planta) obteve-se os teores de 4,99 e $4,18 \mathrm{~g} \mathrm{~kg}^{-1}$. Na Figura 19B pode-se observar estas interações. Dentro dos limites testados da adubação das mudas, as relações dos teores de $\mathrm{Mg}$ nas raízes foram inversos às doses de $K$, como nos resultados de Smith et al. (1954). Já os teores do nutriente no caule relacionaram-se diretamente com as doses de K (Tabela 8).

O efeito positivo do $\mathrm{N}$ sobre os teores de Mg já haviam sido demonstrados por Smith (1966); Reese \& Koo (1975) e Koo \& Reese (1977). As referências na literatura sobre os efeitos depressivos da adubação potássica sobre os teores Mg são freqüentes no Brasil (Gallo et al., 1960; Nagai et al., 1975) e nos EUA (Smith, 1966; Chapman, 1968; e Embleton et al., 1978).

As equações da Tabela 7 mostram que os teores de $S$ nas folhas velhas $e$ raizes do limoeiro 'Cravo' aumentaram de 3,48 para 4,04 e de 1,24 para 1,73 g kg' ${ }^{1}$ das doses mínimas de $\mathrm{N}(0,47 \mathrm{~g}$ por planta) para as doses de 5,39 e 4,05 g por planta. Nas folhas novas e caule os teores não variaram significativamente com os tratamentos (Tabela 7). Nas folhas novas e caule das mudas de laranjeira Valência'/Cravo', os teores aumentaram até 2,41 e 0,86 $\mathrm{g} \mathrm{kg}^{-1}$ nas doses de 11,2 e 21,25 g por planta de $N$ (Tabela 8 ). Não houve efeito significativo dos tratamentos sobre os teores de $S$ nas folhas velhas e raízes (Tabela 8). De acordo com Embleton et al. (1978), aumentos nos teores de $N$ tendem a reduzir os teores de $S$ na planta podendo favorecer o efeito negativo da relação entre eles, pois 
uma relação alta reduz o $\mathrm{S}$, e este pode atingir conteúdos que aproximam-se aos da deficiência.

Considerando-se as doses para atingir a produção máxima das mudas: 9,85 g por planta de $\mathrm{N} ; 2,86$ de $\mathrm{P}$ e 7,99 de $\mathrm{K}$, tem-se os teores de $\mathrm{N}$ de 49,9 e $35,64 \mathrm{~g} \mathrm{~kg}^{-1}$ para as folhas novas e velhas, respectivamente. Para $\circ \mathrm{P}$, tem-se 3,39 e 0,95 $\mathrm{g} \mathrm{kg}^{-1}$; para o $\mathrm{K}$, tem-se 23,76 e 34,47 $\mathrm{g} \mathrm{kg}^{-1}$. Considerando as faixas para interpretação propostas pelo GPACC (1994), tem-se que os nutrientes encontram-se nas faixas consideradas excessivas $(\mathrm{N}>30 ; \mathrm{P}>2,0$; e K $>20 \mathrm{~g} \mathrm{~kg}$ ${ }^{1}$ ). No entanto, como o objetivo é o crescimento máximo da muda utilizando-se altos niveis de adubação era esperado que os niveis propostas para plantas adultas não fossem muito adequados para avaliar-se o estado nutricional das mudas.

$\mathrm{O}$ balanceamento entre $\mathrm{K}, \mathrm{Ca}$ e $\mathrm{Mg}$ é de fundamental importância na nutrição de plantas e para os citros é um caso especial em razão da absorção preferencial de $\mathrm{Ca}$, diferentemente da maioria das espécies. Segundo Smith (1975) a quantidade de Ca nas plantas cítricas está diretamente relacionada com a quantidade de Ca suprida pelo substrato. Sendo o Ca o cátion dominante em todas as partes da planta, este padrão de distribuição somente será alterado quando o suprimento do nutriente não for adequado. Provavelmente isto ocorreu nesse experimento, pois o $\mathrm{Ca}$ foi fornecido apenas no plantio e havia necessidade de uma complementação posterior. Isso pode ser evidenciado pelos teores de $\mathrm{Ca}$ obtidos nas folhas das mudas de laranjeira 'Valência'l'Cravo', nos níveis de adubação recomendados $(9,85 \mathrm{~g}$ por planta de $\mathrm{N} ; 2,86$ de $P$ e 7,99 de $K$ ), todos foram menores que $35 \mathrm{~g} \mathrm{~kg}^{-1}$, que segundo 0 GPACC (1994), estão na faixa considerada baixa. No entanto não foram observados sintomas visuais de deficiência de Ca nas folhas das mudas.

Considerando os mesmos niveis de adubação, os teores de $\mathrm{Mg}$ nas folhas novas e velhas estão próximos do limite inferior da faixa considerada adequada (entre 2,5 e $4,0 \mathrm{~g} \mathrm{~kg}^{-1}$ ) pelos autores. Os teores de $S$ nas folhas novas estão 
dentro da faixa considerada adequada (entre 2,0 e $3,0 \mathrm{~g} \mathrm{~kg}^{-1}$ ), segundo GPACC (1994). Castle \& Rouse (1990) obtiveram em um levantamento do estado nutricional nos viveiros da Florida, teores foliares médios de: $N$ 16,9; $\mathrm{P} 1,46 ; \mathrm{K}$ 12,24; Ca 10,89 e Mg 1,46 $\mathrm{g} \mathrm{kg}^{-1}$, para as mudas cultivadas em vasos.

\subsubsection{Acumulação de nutrientes}

Na Tabela 9 estão as equações obtidas para as relações entre adubação NPK e o acumulação e desses nutrientes. As Figuras 20, 21 e 22 ilustram a acumulação total de nutrientes pelo porta-enxerto e pelas mudas.

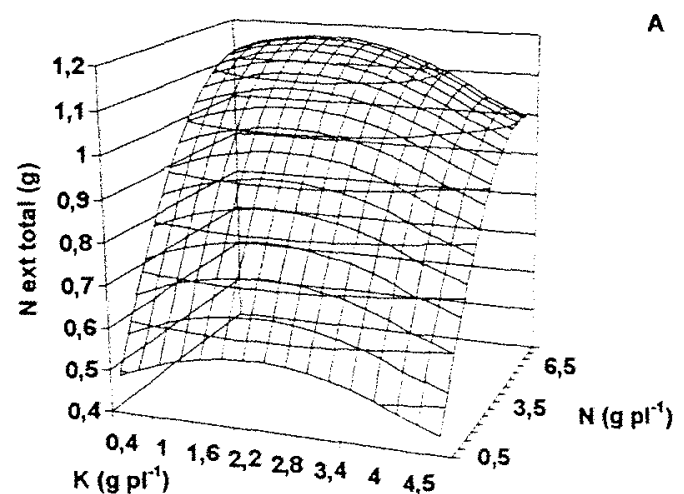

$Y=-0,012 N^{2}+0,189 N-0,02 K^{2}+0,094 K-0,003 N K+0,364 \quad R^{2}=0,823$

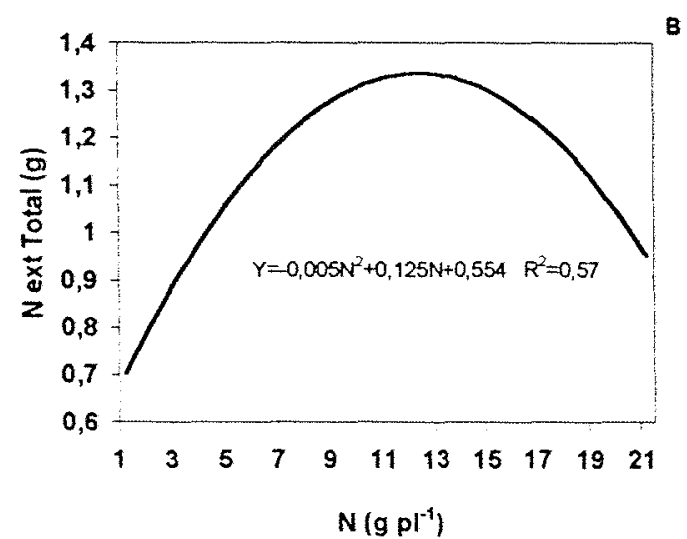

$N\left(g p^{-1}\right)$

Figura 20: Acumulação de $\mathrm{N}$ no limoeiro 'Cravo' (A) e laranjeira 'Valência'l'Cravo' (B).

A acumulação de $\mathrm{N}$ pelas raízes do limoeiro 'Cravo' foi crescente até 7,5 g por planta de $\mathrm{N}$, quando foi extraído $0,32 \mathrm{~g}$ do nutriente. $\mathrm{Na}$ acumulação de $\mathrm{N}$ pela parte aérea e total houve interações entre a adubação com $\mathrm{N}$ e de $\mathrm{K}$. As extrações máximas de 0,78 e 1,17 g de $\mathrm{N}$ evidenciaram o papel positivo do $\mathrm{N}$ e o efeito negativo do K. Estas extrações foram obtidas com as doses de 7,95 e 7,65 g por planta de $\mathrm{N}$, e 0,42 e 1,78 g por planta de $\mathrm{K}$, respectivamente. 
Tabela 9: Função de resposta ajustada para os termos significativos obtidos para a acumulação e uso eficiente de nutrientes pelo limoeiro 'Cravo' e laranjeira 'Valência'/'Cravo'. As condições indicam os niveis dos nutrientes não significativos para os quais as equações foram ajustadas.

\begin{tabular}{|c|c|c|c|}
\hline Variável & Equação & Condição $(\mathrm{g})$ & $\mathrm{R}^{2}$ \\
\hline \multicolumn{4}{|c|}{ Limoeiro 'Cravo' } \\
\hline$N_{P A}$ & $Y=-0,008 N^{2}+0,127 N-0,015 K^{2}+0,0001 K-0,001 N K+0,282$ & $P=0,19$ & 0,777 \\
\hline$N_{R}$ & $Y=-0,004 N^{2}+0,06 N+0,094$ & $P=0,19$ e $K=0,42$ & 0,687 \\
\hline $\mathrm{N}_{\mathbf{T}}$ & $Y=-0,012 N^{2}+0,189 N-0,02 K^{2}+0,094 K-0,003 N K+0,364$ & $P=0,19$ & 0,823 \\
\hline$P_{P A}$ & $Y=-0,0009 N^{2}+0,009 N-0,01 P^{2}+0,041 P+0,00004 N P+0,006$ & $K=4,67$ & 0,705 \\
\hline$P_{R}$ & $Y=0,00004 N^{2}-0,005 N-0,004 P^{2}+0,022 P-0,001 N P+0,01$ & $K=4,67$ & 0,798 \\
\hline Pr & $Y=-0,001 N^{2}+0,009 N-0,014 P^{2}+0,063 P-0,0007 N P+0,038$ & $K=4,67$ & 0,801 \\
\hline$K_{\text {PA }}$ & $Y=-0,002 N^{2}-0,017 N-0,016 K^{2}+0,0149 K-0,002 N K+0,241$ & $P=0,19$ & 0,866 \\
\hline$K_{R}$ & $Y=0,001 N^{2}-0,031 N-0,008 K^{2}+0,064 K-0,001 N K+0,139$ & $P=0,19$ & 0,802 \\
\hline $\mathrm{K}_{\mathrm{T}}$ & $Y=-0,0008 N^{2}-0,048 N-0,024 K^{2}+0,213 K-0,003 N K+0,381$ & $P=0,19$ & 0,889 \\
\hline \multicolumn{4}{|c|}{ Laranjeira 'Valência'/'Cravo' } \\
\hline $\mathrm{N}_{\mathrm{T}}$ & $Y=-0,005 N^{2}+0,125 N+0,554$ & $P=0,19$ e $K=0,42$ & 0,57 \\
\hline $\mathbf{P}_{\mathbf{T}}$ & $Y=-0,001 N^{2}+0,001 N+0,028 P^{2}-0,104 P-0,001 N P+0,387$ & $K=0.42$ & 0,76 \\
\hline $\mathrm{K}_{\mathbf{T}}$ & $Y=0,0002 N^{2}+0,003 N-0,0002 K^{2}+0,0008 K+0,0001 N K+0,047$ & $P=0,19$ & 0,851 \\
\hline
\end{tabular}

A importância das reservas de $\mathrm{N}$ acumulados nas folhas velhas raízes $\mathrm{e}$ caules, de acordo com Legaz et al. (1995), são observadas nas novas vegetações, uma vez que os autores detectaram em seus estudos que mais de $70 \%$ do $\mathrm{N}$ acumulado nos órgãos novos durante a fase de vegetação originaramse das reservas em órgãos mais velhos.

Houve interação entre os fertilizantes nitrogenado e fosfatado sobre a acumulação de $\mathrm{P}$ pela parte aérea, raízes e total do porta-enxerto. Os valores máximos de 0,$069 ; 0,036$ e $0,12 \mathrm{~g}$ de $P$ foram obtidos com as doses de 4,54; 0,47 e 3,75 g por planta de $\mathrm{N}$ e 2,06; 1,77 e 2,16 g por planta de $\mathrm{P}$.

A interação negativa do fertilizante nitrogenado sobre o $\mathrm{K}$ na planta refletiu também na acumulação do nutriente pelo limoeiro 'Cravo'. As maiores 
extrações de $\mathrm{K}$ pela parte aérea, raizes e total $(0,58 ; 0,25$ e 0,82 g por planta, respectivamente) foram obtidas nas menores doses de $\mathrm{N}(0,47 \mathrm{~g}$ por planta) e maiores de $\mathrm{K}(4,67 \mathrm{~g}$ por planta).
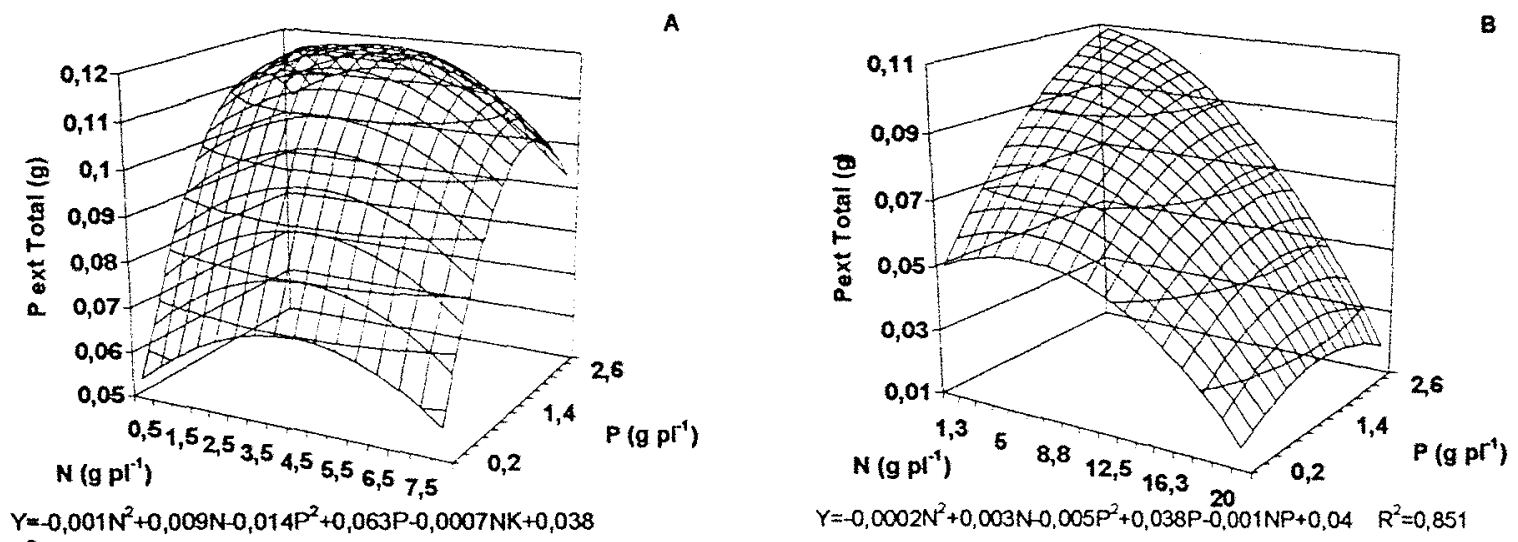

Figura 21: Acumulação de $P$ no limoeiro 'Cravo' (A) e laranjeira 'Valência'l'Cravo' (B).

Estas avaliações têm um interesse especial com relação ao portaenxerto, uma vez que o sistema utilizado para o forçamento da brotação da borbulha foi a decepação da parte aérea. Pelos resultados apresentados, nas extrações máximas de nutrientes, observou-se que $33,3 \%$ do $N, 30 \%$ do $P$ e $30 \%$ do K estava nas raizes, e o restante foi extraido pela parte aérea.

Nas mudas de laranjeira 'Valência'l'Cravo', a acumulação total de N cresceu até $1,34 \mathrm{~g}$ de $\mathrm{N}$, obtido com $12,5 \mathrm{~g}$ por planta de $\mathrm{N}$. Na acumulação total de $P$ houve interação entre $N$ e $P$, e a quantidade máxima de $P$ absorvida $(0,108 \mathrm{~g}$ por planta de $\mathrm{P})$ foi alcançada com 2,67 e 2,99 g por planta de $\mathrm{N}$ e de $P$, respectivamente. $\mathrm{Na}$ acumulação de $\mathrm{K}$ houve interação entre $\mathrm{N}$ e K. O efeito foi negativo para o fornecimento de $\mathrm{N}$ e positivo para o de $\mathrm{Ke}$, a quantidade máxima de $\mathrm{K}$ absorvido (1,89 g por planta), foi obtida com 1,25 e 12,45 g por planta de $\mathrm{N}$ e de $\mathrm{K}$, respectivamente. 


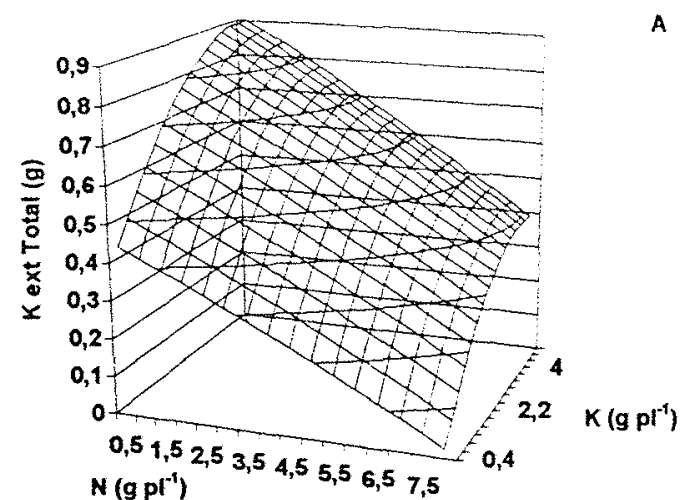

$Y=-0,001 N^{2}-0,048 N-0,024 K^{2}+0,213 K-0,003 N K+0,381$

A

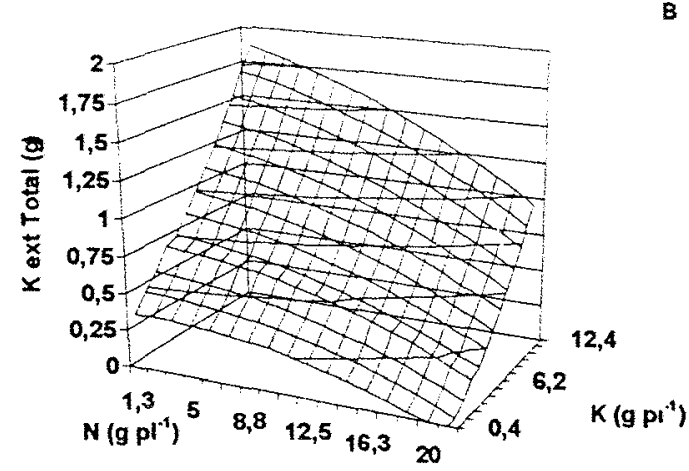

$Y=0,001 N^{2}+0,002 N+0,003 K^{2}+0,09 K-0,002 N K+0,336 . R^{2}=0,76$

Figura 22: Acumulação de $K$ no limoeiro 'Cravo' (A) e laranjeira 'Valência'l'Cravo' (B).

\subsection{Conclusões}

Os resultados obtidos permitem concluir que:

A ordem decrescente dos teores de macronutrientes nos órgãos analisados foram: folhas velhas, folhas novas, raizes e caule.

A adubação nitrogenada relacionou-se diretamente com os teores de $\mathrm{Ne}$ inversamente como os de $\mathrm{P}$ e $\mathrm{K}$. Os teores de $\mathrm{Ca}, \mathrm{Mg}$ e $\mathrm{S}$ relacionaram-se positivamente com a adubação nitrogenada até os niveis intermediários.

Houve efeito inibitório do K sobre a absorção de Ca e Mg.

A acumulação de NPK pelos porta enxertos foi em torno de $30 \%$ pelas raízes e $70 \%$ pela parte aérea. 


\section{CONCLUSÕES GERAIS}

Dos resultados obtidos e dentro dos limites testados, pode-se concluir que:

Para a produção das mudas, as doses de $\mathrm{N}$ e K, calculadas a partir da área foliar foram sempre maiores que aquelas que somente consideram a produção de material seco total. Isso foi observado tanto na produção dos porta-enxertos de limoeiro 'Cravo', como das mudas de laranjeira 'Valência'l'Cravo'.

As doses excessivas de $\mathrm{N}$ utilizadas limitaram a fotossintese. As doses intermediárias da adubação potássica interferiram positivamente nos parâmetros. O P teve pouca influência nos parâmetros avaliados. No portaenxerto limoeiro 'Cravo', a assimilação de $\mathrm{CO}_{2}$, transpiração, e eficiência do uso da água do foram relacionados com os teores foliares de $K$. Nas mudas de laranjeira 'Valência', a assimilação de $\mathrm{CO}_{2}$ e a eficiência do uso da água do foram relacionados positivamente com os teores foliares de $\mathrm{K}$ e a concentração interna de $\mathrm{CO}_{2}$ negativamente.

A ordem decrescente dos teores de macronutrientes nos órgãos analisados foram: folhas velhas, folhas novas, raizes e caule. A adubação nitrogenada relacionou-se diretamente com os teores de $\mathrm{N}$ e inversamente como os de $\mathrm{P}$ e $\mathrm{K}$. Os teores de $\mathrm{Ca}, \mathrm{Mg}$ e $\mathrm{S}$ relacionaram-se positivamente com a adubação nitrogenada até os niveis intermediários. Houve efeito inibitório do $\mathrm{K}$ sobre a absorção de $\mathrm{Ca}$ e Mg. A acumulação de NPK pelos porta enxertos foi em torno de $30 \%$ pelas raízes e $70 \%$ pela parte aérea. 


\section{REFERÊNCIAS BIBLIOGRÁFICAS}

AMARO, A.A.; MAIA, M.L. Produção e comércio de laranja e de suco no Brasil. Laranja, v.18, n.1, p.1-12, 1997.

ARAÚJO, S.C.; SOUZA, M. Influência da adubação e vigor dos ramos porta borbulhas na qualidade dos enxertos de citros. Ciência e Prática, v.18, n.2, p.151-157, 1994.

BARKER, A.V. Nutritional factors in photosynthesis of higher plants. Journal of Plant Nutrition, v.1, n.3, p.309-342, 1979.

BASSHAM, J.A.; LARSEN, P.O.; LAWYER, A.L.; CORNWELL, K.L. Relationships between nitrogen metabolism and photosynthesis. In: BEWLEY, J.D. Nitrogen and carbon metabolism. The Hague, Martinus Nijhoff. 1981. p.135-163.

BEVINGTON, K; CASTLE, W.S. Annual root growth pattern of young citrus trees in relation to shoot growth, soil temperature, and soil water content. Journal American Society of Horticultural Science, v.110, n.6, p.840845, 1985.

BRIDGES, G.D. \& YOUTSEY, C.O. Cultural pratices in Florida citrus nurseries. In: INTERNATIONAL CITRUS CONGRESS, Riverside, 1977. Proceedings. Riverside, International Society of Citriculture, 1977. p.1214. 
BUENO, D.M.; SOUZA, M. Superfosfato triplo para porta-enxertos de citros em diferentes tipos de solos. II. Influência nas componentes de substrato. Revista Brasileira de Fruticultura, v.11, n.1, p.53-57, 1989.

CANTARELLA, H.; QUAGGIO, J.A.; BATAGLIA, O.C.; RAIJ, B. Response of citrus to NPK fertilization in a network of field trials in São Paulo State, Brazil. In: INTERNATIONAL CITRUS CONGRESS, Acireale, 1992. Proceedings. Acireale, International Society of Citriculture, 1992. p.607-12

CARVALHO, S.A. Produção de porta-enxertos cítricos, sob doses crescentes de nitrato de potássio. Pesquisa Agropecuária Brasileira, v.29, n.1, p.8790, 1994.

CARVALHO, S.A. Estratégias para estabelecimento e manutenção de matrizes, borbulheiras e viveiro de citros em ambiente protegido. In: DONADIO, L.C.; RODRIGUEZ, O.(ed.) SEMINÁRIO INTERNACIONAL DE CITROS - TRATOS CULTURAIS, V. Bebedouro, 1998. Anais. Bebedouro, Fundação Cargill, 1998. p.67-101.

CARVALHO, S.A.; SOUZA, M. de. Resposta do limoeiro 'Cravo' em sementeira a dois métodos de aplicação de superfosfato simples. In: CONGRESSO BRASILEIRO DE FRUTICULTURA, 9, Campinas, Anais. Campinas: Sociedade Brasileira de Fruticultura, v.2, p.429-434, 1988

CARVALHO, S.A.; LARANJEIRA, F.F. Protótipo de viveiro de mudas certificadas e borbulheiras sob telado à prova de afídeos do Centro de Citricultura-IAC. Laranja, v.15, n.2, p.213-220, 1994.

CASTLE, W.S. Citrus root systems: their structure, function, growth, and relationship to tree performance. In: INTERNATIONAL CITRUS CONGRESS, Sidney, 1978. Proceedings. Sidney, International Society of Citriculture, 1978. p.62-69. 
CASTLE, W.S.; ADAMS, W.G.; DILLEY, R.L. An indoor container system for producing citrus nursery trees in one year from seed. Proceedings of Florida State Horticultural Society, v.92, p. 3-7. 1979.

CASTLE, W.S.; FERGUNSON, J.J. Current status of greenhouse and container production of citrus nursery trees in Florida. Proceedings of Florida State Horticultural Society, v.95, p. 42-6. 1982.

CASTLE, W.S.; ROUSE, R.E. Total mineral nutrient content of Florida citrus nursery plants. Proceedings of Florida State Horticultural Society, v. 103, p. 42-4. 1990.

CHAPMAN, H.D. The mineral nutrition of citrus. In: REUTER, V; BATCHELOR, L.D.; WEBBER, $H$., ed. The citrus industry. Berkeley, University of California, 1968. p.127-289.

CHAPMAN, H.D.; LIEBIG, G.F. The effects of various nitrate concentration on the growth and composition of sweet orange seedlings. Soil Science Society America Proceedings, v.2, p.359-365, 1937.

CHAPMAN, H.D.; RAYNER, D.S. Effect of various maintained levels of phosphate on the growth, yield, composition, and quality of Washington Navel oranges. Hilgardia, v.20, n.17, p.325-347, 1951.

COETZEE, J.G.K.; ESSELEN, L.; VAN ROOYEN, A. Fertilization of nursery trees - alternative method. In: WORLD CONGRESS OF THE INTERNATIONAL SOCIETY OF CITRUS NURSERYMEN. South Africa, 1993, II. Proceedings. South Africa, Internationational Society of Citrus Nurserymen, 1993. p.143-150.

COETZEE, J.G.K. Fertilization in citrus nurseries, Citrus Journal, v.5, n.2, 1995. 
COETZEE, J.G.K.; ESSELEN, L.; VAN ROOYEN, A. Fertilization of nursery trees - alternative method. In: WORLD CONGRESS OF THE INTERNATIONAL SOCIETY OF CITRUS NURSERYMEN. South Africa, 1993, II. Proceedings. South Africa, International Society of Citrus Nurserymen, 1993. p.143-150.

CONAGIN, A.; JORGE, J.P.N. Delineamento $(1 / 5)(5 \times 5 \times 5)$ em blocos. Bragantia, v.41, p.155-168, 1982.

DECARLOS NETO, A.; DE GRANDI, A.J.; VICHIATO, M.; AMARAL, AM. do; SOUZA, M. de. Viabilização do uso de tubetes para obter o porta-enxerto limoeiro 'Cravo' com "solução de arranque". In: CONGRESSO BRASILEIRO DE FRUTICULTURA, 13, Salvador. Anais. Sociedade Brasileira de Fruticultura, 1994. v.3, p.400-401.

EMBLETON, T.W.; JONES, W.W.; LABANAUSKAS, C.K; REUTHER, W. Leaf analysis as a diagnostic tool and guide to fertilization. In: REUTER, V., ed. The citrus industry. Berkeley, University of California, 1973. p.183-210.

EMBLETON, T.W.; JONES, W.W.; PALLARES, C.; PLATT, R.G. Effects of fertilization of citrus on fruit quality and ground water nitrate-pollution potencial. In: INTERNATIONAL CITRUS CONGRESS, Sidney, 1978. Proceedings. Sidney, International Society of Citriculture, 1978. p.280-5.

FAQUHAR, G.D.; von CAEMMERER, S.; BERRY, J.A. A biochemical model of photosynthetic CO2 assimilation in leaves of C3 species. Planta, v.149, n.1, p.78-90, 1980

FEIGENBAUM, S.H.; BIELORAI, H.; ERNER, Y.; DASBERG, S. The fate of ${ }^{15} \mathrm{~N}$ labelled nitrogen applied to mature citrus trees. Plant and Soil, Dodrechet, v.97, n. , p.179-187, 1987. 
FORD, H.W.; REUTHER, W.; SMITH, P.F. Effect of nitrogen on root development of Valencia orange trees. Proceedings of Florida State Horticultural Society, v.70, p.234-244, 1957.

GALLO, J.R.; HIROCE, R.; RODRIGUEZ, O.R. Correlação entre composição das folhas e produção e tamanho de frutas de laranjeira Baianinha. Bragantia, v. 25, n. 1, p. $77-88,1966$.

GALLO, J.R.; MOREIRA, S.; RODRIGUEZ, O.; FRAGA JÚNIOR, C.G. Composição inorgânica das folhas de laranjeira Baianinha, com referência à época de amostragem e adubação química. Bragantia, v.19, n.16, p.229-46, 1960.

GAMA-RODRIGUES, A.C.; VALLÉ, R.R. Crescimento, trocas e relações hídricas de plântulas de cacau em função de diferentes fontes de potássio. Revista Brasileira de Ciência do Solo. v.19, n.3, p.387-393, 1995.

GIL, S.; GONZALO, S. Desordenes fisiologicos y necrosis de plantas frutales relacionados com toxicidad del nitrogeno. Revista Fruticola, v.14, n.1, p.14$28,1993$.

GRAFF, C.C.D; MARINHO, C.S.; SOUTO, R.F.; PAIVA, L.V.; SOUZA SOBRINHO, F. Efeito da fertilização foliar após a enxertia no crescimento e nutrição da muda da laranjeira (Citrus sinensis (L.) Osbeck cv. Valência). Ciência e Prática, v.18, n.3, p.264-267, 1994.

GRUPO PAULISTA DE ADUBAÇÃo E CALAGEM PARA Citros. Recomendação de adubação e calagem para citros no Estado de São Paulo. Laranja, 1994. 27p.

HOPIKINS, W.G. Introduction to plant physiology. New York: John Wiley, 1995. $464 p$. 
HUBER, S.C. Role of potassium in photosynthesis and respiration. In: MUNSON, R.D. ed. Potassium in agriculture. Madison, Soil Science Society of America. 1985. p.369-396.

KATO, T. Nitrogen metabolism and utilization in citrus. Horticultural Reviews, v.8, p.181-216, 1986.

KHAIRI, M.M.A.; HALL, A. Comparative studies of net photosynthesis and transpiration of some citrus species and relatives. Physiologia Plantarum, v.36, p.35-39, 1976.

KRIEDEMANN, P.E. Some photosynthetic caracteristic of citrus leaves, Australian Journal of Biological Science, v.21, n.5, p.895-905, 1968.

KRIEDEMANN, P.E. Photosynthesis and transpiration as function of gaseous diffusive resitances in orange leaves. Physiologia Plantarum, v.24, p.218225, 1971.

KOO, R.C.J. Potassium nutrition of citrus. In: MUNSON, R.D. ed. Potassium in agriculture. Madison, Soil Science Society of America. 1985. p.10771086.

KOO, R.C.J. \& REESE, R.L. Influence of nitrogen, potassium, and irrigation on citrus fruit quality. In: INTERNATIONAL CITRUS CONGRESS, Riverside, 1977. Proceedings. Riverside, International Society of Citriculture, 1977. p. 34-8.

LEGAZ, F.; PRIMO-MILLO, E.; PRIMO-YUFERA, E.; GIL, C.; RUBIO, J.L. Nitrogen fertilization in citrus. I.Absorption and distribuition of nitrogen in calamondin trees during flowering, fruit set and initial fruit development periods. Plant and Soil, v.66, p.339-351, 1982. 
LEGAZ, F.; SERNA, M.D.; PRIMO-MILLO, E. Mobilization of the reserve $\mathrm{N}$ in citrus. Plant and Soil, v.173, n.2, p.205-210, 1995.

LIMA, J.E.O. Novas técnicas de produção de mudas cítricas. Laranja, v.2, n.7, p. $463-8.1986$.

LONG, S.P.; HALLGREN, J.E. Measurement of $\mathrm{CO}_{2}$ assimilation by plants in the field and the laboratory. In: COOMBS, J.; HALL, D.O.; LONG, S.P.; SCURLOCK; J.M.O. Techniques in bioproductivity and photosyntheseis. $2^{\text {nd }}$ ed. Oxford: Pergamon Press, 1987. p.62-94.

LONGSTRETH, D.J.; NOBEL, P.S. Nutrient influences on leaf photosynthesis. Plant Physiology, v.65, p.541-543, 1980.

MACHADO, E.C.; PEREIRA, A.R. Um sistema para medição de fluxos de gás carbônico em raízes e parte aérea em plantas intactas. Pesquisa Agropecuária Brasileira. v.25, p.935-944, 1990.

MAGALHÃES, A.C.N. Análise quantitativa do crescimento. In: FERRI, M.G. coord. Fisiologia vegetal. $2^{\mathrm{a}}$ ed. vol.1. São Paulo: Ed. Pedagógica e Universitária, 1985. p.333-350.

MALAVOLTA, E. Leaf analysis in Brazil - present and perspectives. In: INTERNATIONAL CITRUS CONGRESS, Acireale, 1992. Proceedings. Acireale, International Society of Citriculture, 1992. p.570-4.

MALAVOLTA, E.; VITTI, G.C.; OLIVEIRA, S.A. Avaliação do estado nutricional das plantas: princípios e aplicações. Piracicaba, POTAFOS, 1989. $201 p$.

MARSCHNER, $H$. Mineral nutrition of higher plants. New York: Academic Press, 1995. 889p. 
MAUST, B.E.; WILLIAMSON, J.G. Nitrogen rate effect on growth of containerized citrus nursery plants. Proceedings of Florida State Horticultural Society, v.104, p.191-195, 1991.

MAUST, B.E.; WILLIAMSON, J.G. Nitrogen nutrition of containerized citrus nursery plants. Journal of American Society for Horticultural Science, v.119, n.2, p.195-201, 1994.

MEDINA, C.L.; MACHADO, E.C. Trocas gasosas e relações hídricas em laranjeira 'Valência' enxertada sobre limoeiro 'Cravo' e Trifoliata e submetida à deficiência hídrica. Bragantia, v.57, n.1, p.17-22, 1998.

MENGEL, K.; KIRKBY, E.A. Principles of plant nutrition. $3^{\text {th }}$ ed. Bern: International Potash Institute, 1982. 655p.

MILLER, J.E.; HOFMAN, P.J.; BERRY, R.K. Physiological and nutritional responses of five citrus rootstocks to potassium. Journal of the Southern African Society for Horticultural Sciences, Pietermaritzburg, v.3, n.1, p.20-23, 1993.

MOORBY, J.; BESFORD, R.T. Mineral nutrition and growth. In: GÖTTING, A.P.; HARVARD, M.H. Inorganic plant nutrition. v. 15B, Berlin: SpringerVerlag, 1983. p.481-527.

NAGAI, V.; IGUE, T.; HIROCE, R. Estudo comparativo das relações entre os nutrientes dosados em folhas de café, citros e milho. Bragantia, v.34, p.XXIIIXXVII, 1975.

NATR, L. Influence of mineral nutrients on photosynthesis of higher plants. Photosynthetica, v.6, p.80-99, 1972. 
PANZANI, C.R.; PRATES, H.S.; GREVE, A. Sistema de produção de muda certificada de citros no Estado de São Paulo. Laranja, v.15, n.1, p.175-199, 1994.

PLATT, R.G.; OPITZ, K. Propagation of citrus. In: REUTHER, W. ed. The citrus industry. Berkeley, University of California, 1973. v. 3. p. 1-47.

REESE, R.L.; KOO, R.C.J. Effects of $\mathrm{N}$ and $\mathrm{K}$ fertilization on leaf analysis, tree size and yield of three major Florida orange cultivars. Journal American Society of Horticultural Science, v.100, n.2, p.195-198, 1975.

REITZ, H.J.; KOO, P.C.J. Effect of nitrogen and potassium fertilization on yield, fruit quality, and leaf analysis of 'Valencia' orange. Proceedings of the American Society for Horticultural Science, v.59, p.1-12, 1960.

REUTHER, W. \& SMITH, P.F. Leaf analysis of citrus. In: CHILDERS, N.F. ed. Fruit nutrition, New Brunswick, Rutger University, 1954. p.257-94.

REZENDE, L.P.; AMARAL, A.M.; CARVALHO, S.A.; SOUZA, M. Volume do substrato e superfosfato simples na formação do limoeiro 'Cravo' em vasos. I. Efeitos no crescimento vegetativo. Laranja, v.16, n.2, p.155-164, 1995.

SARRUGE, J.R.; HAAG, H.P. Análises químicas em plantas. Piracicaba: ESALQ/Departamento de Química, 1974. 56p.

SAS INSTITUTE INC. The SAS-sytstem for windows: release 6.11 (software).Cary, 1996.

SEMPIONATO, O.R.; GIROTTO, L.F.; STUCHI, E.S. Produção de mudas sadias. In: DONADIO, L.C.; MOREIRA, C.S. Clorose variegada dos citros. Bebedouro, FUNDECITRUS. 1997. p.75-92. 
SINCLAIR, T.R; ALLEN JR., L.H. Carbon dioxide and water vapour exchange of leaves on field-grown citrus trees. Journal of Experimental Botany, v.33, n.137, p.116-1175, 1982.

SMITH, P.F. Effect of nitrogen source and placement on the root development of Valencia oranges trees. Proceedings of Florida State Horticultural Society, v.78, p55-59, 1965.

SMITH, P.F. Citrus nutrition. In: CHILDERS, N.F., ed. Nutrition of fruit crops; temperate to tropical fruit. New Brunswick, Rutgers the State of Universit, 1966. p.174-207.

SMITH, P.F. Calcium requeriments of citrus. Communications in Soil Science and Plant Analysis, v.6, n.3, p.245-260, 1975.

SMITH, P.F.; REUTHER, W. Seasonal changes in Valencia orange trees. I. changes in in leaf dry weight, ash and macro-nutrient elements. Proceedings of American Society of Horticultural Science, v.55, p.61-72, 1950.

SMITH, P.F.; REUTHER, W.; SPECHR, W.; HRNCIAR, G. Effect of diferential nitrogen, potassium, and magnesium supply to young Valencia orange trees in sand culture on mineral composition especially of leaves and fibrous roots. Plant Physiology, v.40, p.349-355, 1954.

SIVAK, M.N.; WALKER, D.A. Photosynthesis in vivo can be limited by phosphatate suply. New Phytologist, v.102, n.4, p.499-512, 1986.

SYVERTSEN, J.P. Light acclimation in citrus leaves: $\| \mathrm{CO}_{2}$ assimilation and light, water, and nitrogeg use efficiency. Joumal of the American Society for Horticultural Science, v.109, p.812-817, 1984.

SYVERTSEN, J.P. $\mathrm{CO}_{2}$ assimilation and water use efficiency of young expanding citrus leaves. Acta Horticulture, v.171, p.229-236, 1985 
SYVERTSEN, J.P. Nitrogen content and $\mathrm{CO}_{2}$ assimilation characteristics of Citrus leaves. HortScience, v.22, n.2, p.289-291, 1987.

SYVERTSEN, J.P.; LLOYD, J. Citrus. In: SCHAEFFER, B.; ANDERSEN, P. (ed.). Handbook of environmental physiology of fruits crops: subtropical and tropical crops. Boca Raton: CRC Press, 1994, v.2, p.65-99.

TEÓFILO SOBRINHO, J. Propagação dos citros. In: RODRIGUEZ, O. ed. Citricultura Brasileira. Campinas: Fundação Cargill, 1991. v.1. p.281301.

WALLACE, A.; ZIDAN, Z.I.; MULLER, R.T; NORTH, C.P. Translocations of niitrogen in citrus. Proceedings of American Society of Horticultural Science, v.64, p.87-104, 1954.

WEIR, C.C. Nutrient element balance in citrus nutrition. Plant and Soil, v.30, n.3, p.405-14, 1969.

WILLIAMSON, J.G.; CASTLE, W.S. A survey of Florida citrus nurseries. Proceedings of Florida State Horticultural Society, v.102, p.78-82, 1989.

WITT, H.H. Root growth of trees as influenced by physical and chemical soilfactors. Acta Horticulturae, n.450, p.205-214, 1997. 